\title{
An Optimized Groundwater Extraction System for the Toxic Burning Pits Area of J-Field, Aberdeen Proving Ground, Maryland
}

\section{RECEIVED \\ AUG 12 1996. \\ OSTI}

Environmental Assessment Division Argonne National Laboratory 


\section{Argonne National Laboratory}

Argonne National Laboratory, with facilities in the states of Illinois and Idaho, is owned by the United States Government, and operated by the University of Chicago under the provisions of a contract with the Department of Energy.

This technical memo is a product of Argonne's Environmental Assessment 'Division (EAD). For information on the division's scientific and engineering activities, contact:

Director, Environmental Assessment Division

Argonne National Laboratory

Argonne, llinois 60439-4815

Telephone (708) 252-3107

Presented in this technical memo are preliminary results of ongoing work or work that is more limited in scope and depth than that described in formal, reports issued by the EAD.

Publishing support services were provided by Argonne's Information and Publishing Division 'for more information, see IPD's home page: http://www.jpd.anl.gov/

\section{Disclaimer}

This report was prepared as an account of work sponsored by an agency of the United States Government. Neither the United States Government nor any agency thereof, nor any of their employees, makes any warranty, express or implied, or assumes any legal liability or responsibility for the accuracy, completeness, or usefulness of any information, apparatus, product, or process disclosed, or represents that its use would not infringe privately owned,rights. Reference herein to any specific commercial product, process, or service by trade name, trademark, manufacturer, or otherwise, does not necessarily constitute or imply its endorsement, recommendation, or favoring by the United States Government or any agency thereof. The views and opinions of authors expressed herein do not necessarily state or reflect those of the United States Government or any agency thereof. of Scientific and Technical Information, P.O. Box 62 , Oak Ridge, TN 37831 ; prices available from (423) 576-8401. 


\title{
An Optimized Groundwater Extraction System for the Toxic Burning Pits Area of J-Field, Aberdeen Proving Ground, Maryland
}

\author{
by J.J. Quinn, R.L. Johnson, T.L. Patton, and L.E. Martino
}

Environmental Assessment Division,

Argonne National Laboratory, 9700 South Cass Avenue, Argonne, Illinois 60439

\section{DISCLAIMER}

This report was prepared as an account of work sponsored by an agency of the United States Government. Neither the United States Government nor any agency thereof, nor any of their employees, makes any warranty, express or implied, or assumes any legal liability or responsibility for the accuracy, completeness, or usefulness of any information, apparatus, product, or process disclosed, or represents that its use would not infringe privately owned rights. Reference herein to any specific commercial product, process, or service by trade name, trademark, manufacturer, or otherwise does not necessarily constitute or imply its endorsement, recommendation, or favoring by the United States Government or any agency thereof. The views and opinions of authors expressed herein do not necessarily state or reflect those of the United States Government or any agency thereof.

June 1996

Work sponsored by U.S. Army Aberdeen Proving Ground,

Directorate of Safety, Health and Environment 
This report is printed on recycled paper. 
DISCLAIMER

Portions of this document may be illegible in electronic image products. Images are produced from the best available original document. 


\section{CONTENTS}

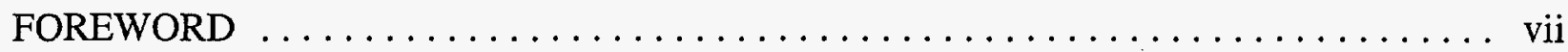

NOTATION $\ldots \ldots \ldots \ldots \ldots \ldots \ldots \ldots \ldots \ldots \ldots \ldots \ldots \ldots \ldots \ldots \ldots \ldots \ldots \ldots$ viii

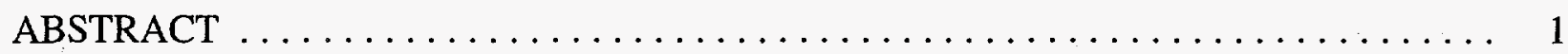

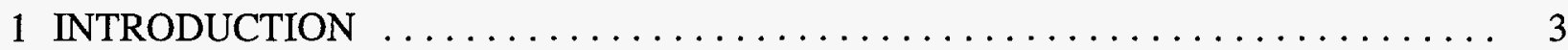

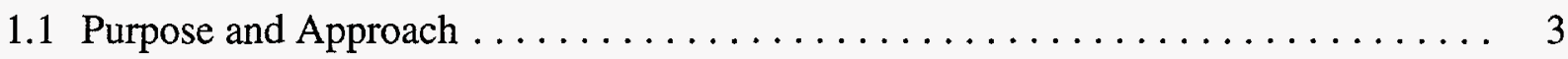

1.2 Site Location and Background $\ldots \ldots \ldots \ldots \ldots \ldots \ldots \ldots \ldots \ldots \ldots \ldots \ldots \ldots \ldots$

2 GEOLOGIC AND HYDROLOGIC SITE CHARACTERIZATION $\ldots \ldots \ldots \ldots \ldots$

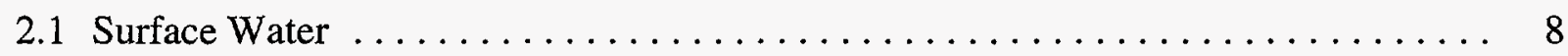

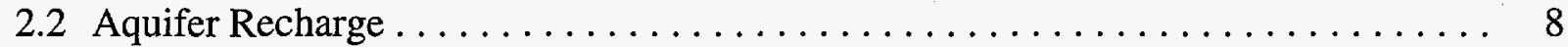

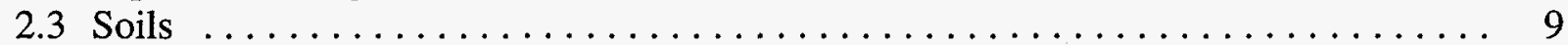

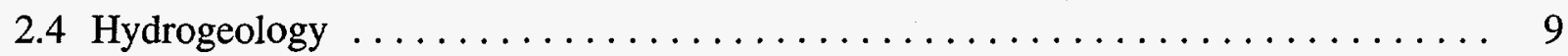

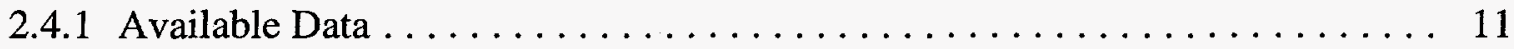

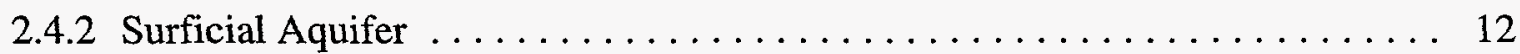

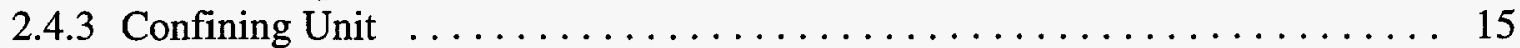

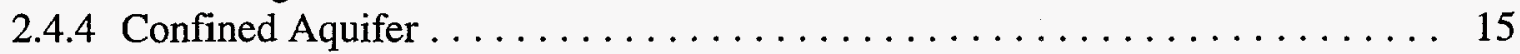

2.4.5 Cretaceous Sediments . . . . . . . . . . . . . . . . . . . . 16

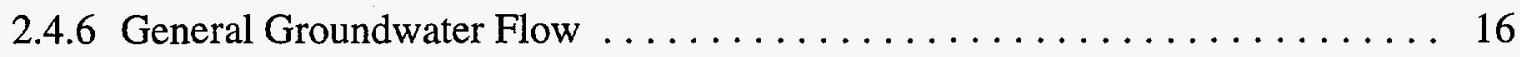

3 GROUNDWATER FLOW MODEL $\ldots \ldots \ldots \ldots \ldots \ldots \ldots \ldots \ldots \ldots \ldots \ldots \ldots$

3.1 Conceptual Groundwater Model $\ldots \ldots \ldots \ldots \ldots \ldots \ldots \ldots \ldots \ldots \ldots \ldots$

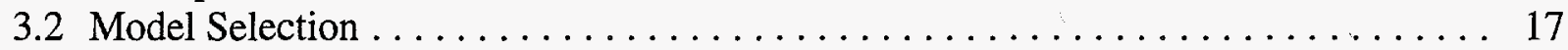

3.3 Grid Design and Boundary Conditions $\ldots \ldots \ldots \ldots \ldots \ldots \ldots \ldots \ldots \ldots \ldots \ldots \ldots \ldots \ldots \ldots \ldots \ldots$

3.4 Geostatistical Modeling of Hydrostratigraphic Surfaces . . . . . . . . . . . 21

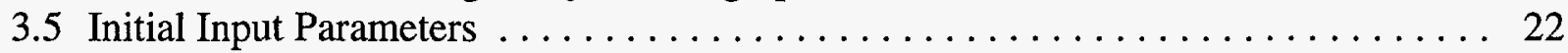

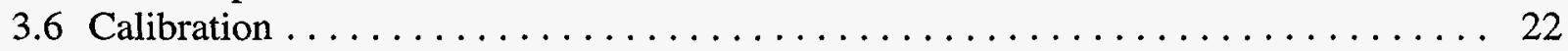

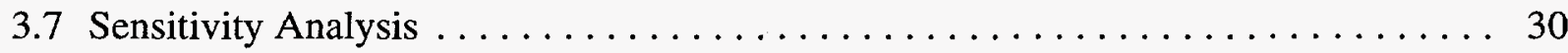

4 OPTIMIZATION OF PUMPING STRESSES $\ldots \ldots \ldots \ldots \ldots \ldots \ldots \ldots \ldots \ldots \ldots \ldots \ldots \ldots$

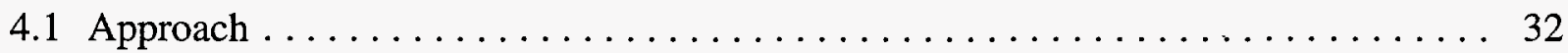

4.2 Model Selection . . . . . . . . . . . . . . . . . . . . . . . . . 32

4.3 Optimization of Extraction Well Placement and Pump Rates . . . . . . . . . 32

4.3.1 Containment .................................. 34

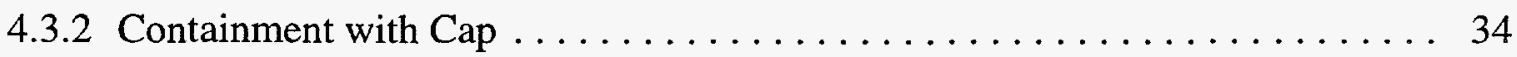

4.3.3 Sensitivity of Optimized Solution to Aquifer Parameters . . . . . . . . . 34

4.3.4 Discussion of Optimization Results . . . . . . . . . . . . . . . . 37 


\section{CONTENTS (Cont.)}

5 SUMMARY AND RECOMMENDATIONS $\ldots \ldots \ldots \ldots \ldots \ldots \ldots \ldots \ldots \ldots, 40$

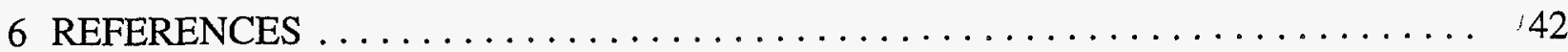

APPENDIX A: Hydrostratigraphic Contact Data for Geostatistical Interpolation ....... A-1

APPENDIX B: Model Calibration Summaries $\ldots \ldots \ldots \ldots \ldots \ldots \ldots \ldots \ldots$ B-1

APPENDIX C: Model Sensitivity Summaries $\ldots \ldots \ldots \ldots \ldots \ldots \ldots \ldots \ldots \ldots \ldots \ldots \ldots$

\section{FIGURES}

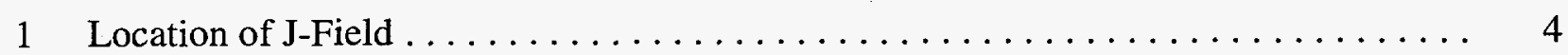

2 Location of Toxic Burning Pits Area, Approximate J-Field Topography,

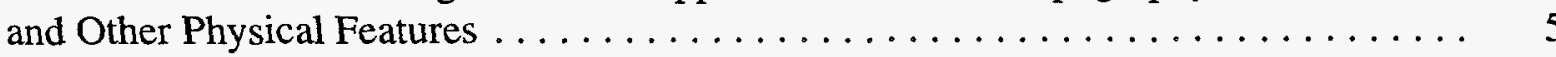

3 Pits and Monitoring Wells in the Toxic Burning Pits Area $\ldots \ldots \ldots \ldots \ldots \ldots$

4 Generalized North-South Stratigraphic Cross Section of J-Field $\ldots \ldots \ldots \ldots \ldots$

5 Model Grid and Boundary Conditions for J-Field $\ldots \ldots \ldots \ldots \ldots \ldots \ldots \ldots$

6 Model Grid and Boundary Conditions for the Toxic Burning Pits Area $\ldots \ldots \ldots \ldots 20$

7 Elevation of Contact between the Surficial Aquifer and the Confining Unit ...... 23

8 Elevation of Contact between the Confining Unit and the Confined Aquifer . . . . . 24

9 Elevation of Contact between the Confined Aquifer and the Cretaceous Sediments . . 25

10 Simulated Heads in Surficial Aquifer . . . . . . . . . . . . . . . . . . 27

11 Simulated Heads in Surficial Aquifer in Toxic Burning Pits Area $\ldots \ldots \ldots \ldots .28$

12 Simulated Heads in Confined Aquifer $\ldots \ldots \ldots \ldots \ldots \ldots \ldots \ldots \ldots \ldots . \ldots \ldots$

13 Head Difference Constraint Pairs and Possible Extraction Well Locations

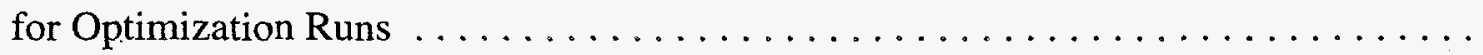




\section{FIGURES (Cont.)}

14 Results for Containment Case with Optimum Seven Wells $\ldots \ldots \ldots \ldots \ldots \ldots \ldots$

15 Results for Containment with Cap Case with Optimum Six Wells $\ldots \ldots \ldots \ldots \ldots$

\section{TABLES}

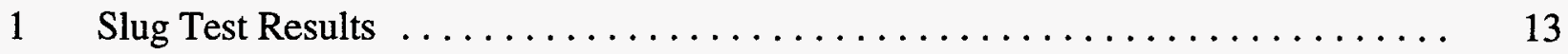

2 Sensitivity of Flow Model to Aquifer Parameters $\ldots \ldots \ldots \ldots \ldots \ldots \ldots \ldots . \quad 31$

3 Sensitivity of Optimization Results to Aquifer Parameters $\ldots \ldots \ldots \ldots \ldots \ldots$

A.1 Hydrostratigraphic Contact Data for Geostatistical Interpolation $\ldots \ldots \ldots \ldots$ A-3

B.1 Calibration Statistics for J-Field Wells: Model Run $16 \ldots \ldots \ldots \ldots \ldots \ldots \ldots$ B-3

B.2 Calibration Statistics for J-Field Wells: Model Run $17 \ldots \ldots \ldots \ldots \ldots \ldots$ B-4

B.3 Calibration Statistics for J-Field Wells: Model Run $18 \ldots \ldots \ldots \ldots \ldots \ldots$ B-5

B.4 Calibration Statistics for J-Field Wells: Model Run $19 \ldots \ldots \ldots \ldots \ldots \ldots \ldots$ B-6

B.5 Calibration Statistics for J-Field Wells: Model Run $20 \ldots \ldots \ldots \ldots \ldots \ldots$ B-7

B.6 Calibration Statistics for J-Field Wells: Model Run $21 \ldots \ldots \ldots \ldots \ldots \ldots$ B-8

B.7 Calibration Statistics for J-Field Wells: Model Run $22 \ldots \ldots \ldots \ldots \ldots \ldots$ B-9

B.8 Calibration Statistics for J-Field Wells: Model Run $23 \ldots \ldots \ldots \ldots \ldots \ldots \ldots$ B-10

B.9 Calibration Statistics for J-Field Wells: Model Run $24 \ldots \ldots \ldots \ldots \ldots \ldots$ B-11

B.10 Calibration Statistics for J-Field Wells: Model Run $25 \ldots \ldots \ldots \ldots \ldots \ldots$ B-12

B.11 Calibration Statistics for J-Field Wells: Model Run $26 \ldots \ldots \ldots \ldots \ldots \ldots$ B-13

B.12 Calibration Statistics for J-Field Wells: Model Run $27 \ldots \ldots \ldots \ldots \ldots \ldots$ B-14

C.1 Sensitivity Analysis for J-Field Wells: Model Run $28 \ldots \ldots \ldots \ldots \ldots \ldots \ldots$ C-3

C.2 Sensitivity Analysis for J-Field Wells: Model Run $29 \ldots \ldots \ldots \ldots \ldots \ldots \ldots$ C-4 


\section{TABLES (Cont.)}

C.3 Sensitivity Analysis for J-Field Wells: Model Run $30 \ldots \ldots \ldots \ldots \ldots \ldots \ldots$ C-5

C.4 Sensitivity Analysis for J-Field Wells: Model Run $31 \ldots \ldots \ldots \ldots \ldots \ldots \ldots$ C-6

C.5 Sensitivity Analysis for J-Field Wells: Model Run $32 \ldots \ldots \ldots \ldots \ldots \ldots \ldots$ C-7

C.6 Sensitivity Analysis for J-Field Wells: Model Run $33 \ldots \ldots \ldots \ldots \ldots \ldots$ C-8

C.7 Sensitivity Analysis for J-Field Wells: Model Run $34 \ldots \ldots \ldots \ldots \ldots \ldots \ldots$ C-9

C.8 Sensitivity Analysis for J-Field Wells: Model Run $35 \ldots \ldots \ldots \ldots \ldots \ldots \ldots$ C-10

C.9 Sensitivity Analysis for J-Field Wells: Model Run $36 \ldots \ldots \ldots \ldots \ldots \ldots \ldots$ C-11

C.10 Sensitivity Analysis for J-Field Wells: Model Run $37 \ldots \ldots \ldots \ldots \ldots \ldots \ldots$ C-12

C.11 Sensitivity Analysis for J-Field Wells: Model Run $38 \ldots \ldots \ldots \ldots \ldots \ldots$ C-13

C.12 Sensitivity Analysis for J-Field Wells: Model Run $39 \ldots \ldots \ldots \ldots \ldots \ldots \ldots$ C-14

C.13 Sensitivity Analysis for J-Field Wells: Model Run $40 \ldots \ldots \ldots \ldots \ldots \ldots$ C-15

C.14 Sensitivity Analysis for J-Field Wells: Model Run $41 \ldots \ldots \ldots \ldots \ldots \ldots \ldots$ C-16

C.15 Sensitivity Analysis for J-Field Wells: Model Run $42 \ldots \ldots \ldots \ldots \ldots \ldots$ C-17

C.16 Sensitivity Analysis for J-Field Wells: Model Run $43 \ldots \ldots \ldots \ldots \ldots \ldots \ldots$ C-18

C.17 Sensitivity Analysis for J-Field Wells: Model Run $44 \ldots \ldots \ldots \ldots \ldots \ldots \ldots$ C-19

C.18 Sensitivity Analysis for J-Field Wells: Model Run $45 \ldots \ldots \ldots \ldots \ldots \ldots \ldots$ C-20

C.19 Sensitivity Analysis for J-Field Wells: Model Run $46 \ldots \ldots \ldots \ldots \ldots \ldots \ldots$ C-21

C.20 Sensitivity Analysis for J-Field Wells: Model Run $47 \ldots \ldots \ldots \ldots \ldots \ldots \ldots$ C-22 


\section{FOREWORD}

This document was prepared by Argonne National Laboratory, Argonne, Illinois, for the Directorate of Safety, Health and Environment, Aberdeen Proving Ground, Maryland. The text of this report has been approved by the U.S. Army for public release and unlimited distribution. The distribution number is OP-SEC Control No. 1560-A-3. 


\section{NOTATION}

The following is a list of the abbreviations, acronyms, and units of measure used in this document.

\section{ABBREVIATIONS AND ACRONYMS}

$\begin{array}{ll}\text { ANL } & \text { Argonne National Laboratory } \\ \text { AOC } & \text { area of concern } \\ \text { APG } & \text { Aberdeen Proving Ground } \\ \mathrm{K}_{\mathrm{H}} & \text { horizontal hydraulic conductivity } \\ \mathrm{K}_{\mathrm{V}} & \text { vertical hydraulic conductivity } \\ \text { MSL } & \text { mean sea level } \\ \text { RMSE } & \text { root mean squared error } \\ \text { TBP } & \text { Toxic Burning Pits } \\ \text { USGS } & \text { U.S. Geological Survey } \\ \text { WPP } & \text { White Phosphorous Pit } \\ \text { VX } & \text { methylphosphonothioic acid }\end{array}$

UNITS OF MEASURE

$\begin{array}{ll}\mathrm{cm} & \text { centimeter(s) } \\ \mathrm{d} & \text { day(s) } \\ \mathrm{ft} & \text { foot (feet) } \\ \mathrm{ft}^{2} & \text { square foot (feet) } \\ \mathrm{ft}^{3} & \text { cubic foot (feet) } \\ \mathrm{gal} & \text { gallon(s) } \\ \mathrm{ha} & \text { hectare(s) } \\ \mathrm{in} . & \text { inch(es) } \\ \mathrm{km} & \text { kilometer(s) } \\ \mathrm{L} & \text { liter(s) } \\ \mathrm{m} & \text { meter(s) } \\ \mathrm{m}^{2} & \text { square meter(s) } \\ \mathrm{m}^{3} & \text { cubic meter(s) } \\ \mathrm{mi} & \text { mile(s) } \\ \mathrm{min} & \text { minute(s) } \\ \mathrm{s} & \text { second(s) } \\ \mathrm{yr} & \text { year(s) }\end{array}$




\title{
AN OPTIMIZED GROUNDWATER EXTRACTION SYSTEM FOR THE TOXIC BURNING PITS AREA OF J-FIELD, ABERDEEN PROVING GROUND, MARYLAND
}

by

J.J. Quinn, R.L. Johnson, T.L. Patton, and L.E. Martino

\begin{abstract}
Disposal and detonation of chemical warfare agents, explosives, and industrial chemicals at the Toxic Burning Pits area of J-Field, Aberdeen Proving Ground, Maryland, have resulted in groundwater contamination. Concern about migrating contaminants has spurred consideration of an extraction system to provide containment of the plumes. However, such a system is expensive to install and maintain, and the optimal locations and pump rates of extraction wells are difficult to determine when objectives related to the site hydrogeology and potential pumping scheme are considered.
\end{abstract}

A traditional approach to designing a containment well system is to perform a series of trial-and-error simulations to test the effects of various well locations and pump rates. This project used linear programming theory to determine optimal well placement and pump rates for the site. Past site activities included disposal of solvents and other contaminants in pits, which resulted in contamination of the $11-\mathrm{m}$ (35-ft) thick surficial aquifer. The area of concern is surrounded on three sides by a marsh that receives a portion of its input budget as groundwater discharge from the pit area. The objective of optimizing the containment pumping scheme was to minimize the total water pumped. Possible well locations were placed at known source areas. To constrain the problem, the optimization program was instructed to prevent any flow toward the marsh along a user-specified border. Consequently, the optimization routine selected well locations and pump rates so as to produce a groundwater divide along this boundary. The end result of the optimization was a containment system that minimized the quantity of water to be pumped and treated (cost benefit), while avoiding dewatering of the marsh (cost and ecological benefit).

Two containment scenarios were modeled: containment and containment with an impermeable cap over metal-contaminated surficial soils. For each case, optimal well locations with varying individual flow rates were identified to successfully produce a flow divide between the pits and the marsh along most of 
the constraint boundary. The optimization results had low sensitivity to reasonable changes in recharge but high sensitivity to increases in the hydraulic conductivity of the surficial aquifer. Limiting the maximum number of wells provided a means of exploring the cost-related trade-off between the number of wells to be installed and the quantity of water to be treated. 


\section{INTRODUCTION}

\subsection{PURPOSE AND APPROACH}

Testing and disposal of chemical warfare agents, munitions, and industrial chemicals at the J-Field area of the Aberdeen Proving Ground (APG) have resulted in contamination of soil and groundwater. The discharge of contaminated groundwater to on-site marshes and adjacent estuaries poses a potential risk to ecological receptors. The Toxic Burning Pits (TBP) area is of special concern because of its disposal history.

This report describes a groundwater modeling study conducted at J-Field that focused on the TBP area. The goal of this modeling effort was optimization of the groundwater extraction system at the TBP area by applying linear programming techniques. Initially, the flow field in the J-Field vicinity was characterized with a three-dimensional model that uses existing data and several numerical techniques. A user-specified border was set near the marsh and used as a constraint boundary in two modeled remediation scenarios: containment of the groundwater and containment of groundwater with an impermeable cap installed over the TBP area. In both cases, the objective was to extract the minimum amount of water necessary while satisfying the constraints. The smallest number of wells necessary was then determined for each case. This optimization approach provided two benefits: cost savings, in that the water to be treated and the well installation costs were minimized, and minimization of remediation impacts on the ecology of the marsh.

\subsection{SITE LOCATION AND BACKGROUND}

J-Field is in the Edgewood Area of the APG on the Gunpowder Neck Peninsula of Harford County, Maryland. The peninsula is surrounded by tidal estuaries: the Gunpowder River on the west and the Chesapeake Bay on the south and east (Figure-1). J-Field is fairly flat; the highest elevation is between 3 and $4.6 \mathrm{~m}$ (10 and $15 \mathrm{ft}$ ) above mean sea level (MSL) (Figure 2).

J-Field covers roughly 230 ha (580 acres) and includes at least eight areas of concern (AOCs) (Argonne National Laboratory 1995). The TBP area, which is one of the AOCs, occupies about 4 ha ( 9 acres) in the southwest portion of J-Field (Figure 3). Disposal in the pits began in the 1940s; most activity occurred between the late 1940s and the 1960s. The TBP area was used to burn and dispose of materials such as chemical agents, bulk chemical wastes, drummed chemical wastes, high explosives (by open burning or open detonation), nerve agents, incapacitating agents (riot control agents), chlorinated solvents, and blister agents (Nemeth 1989). Occasionally, wastes were pushed out of the pits toward the marsh to the east, thus filling in part of the marsh (Hughes 1993c). 


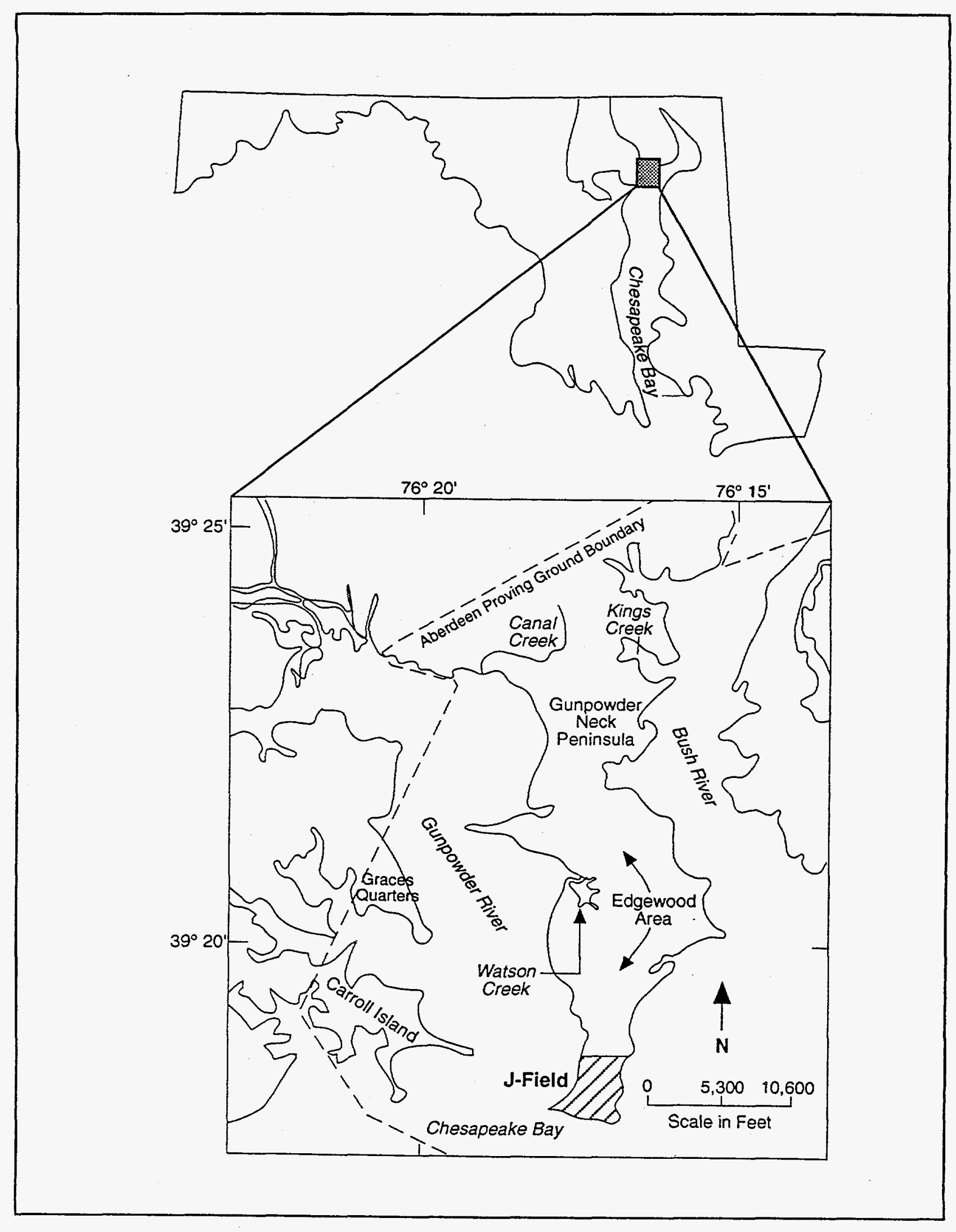

FIGURE 1 Location of J-Field 


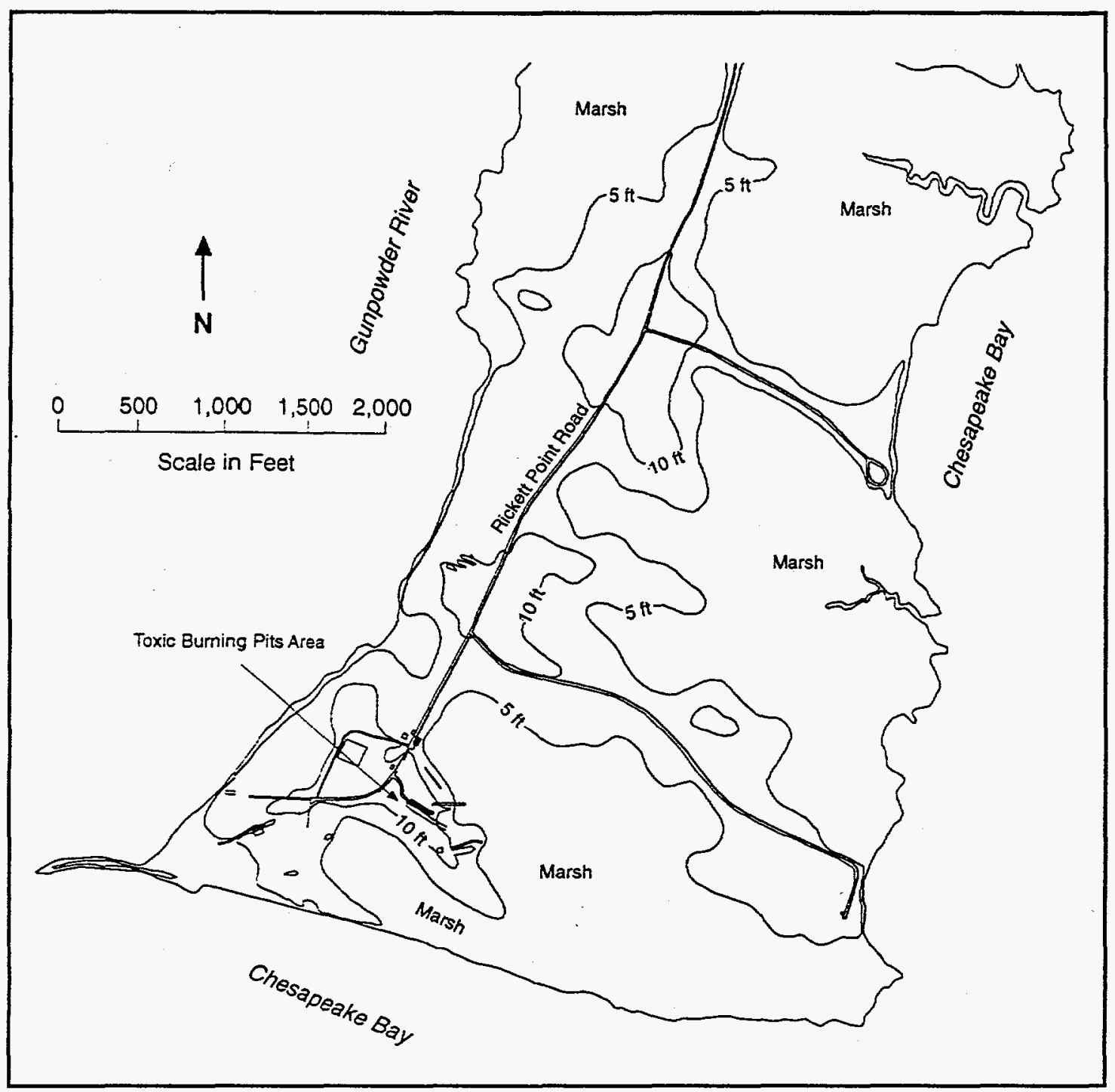

FIGURE 2 Location of Toxic Burning Pits Area, Approximate J-Field Topography, and Other Physical Features

Nemeth (1989) described the TBP area as five trench-like pits. The two main pits are visible at the surface, but the three other pits are now covered. The two main pits are about $46 \mathrm{~m}$ (150 ft) long, and one of them has an extension of about $30 \mathrm{~m}(100 \mathrm{ft})$. Nemeth describes the approximate dimensions of the other three pits. The methylphosphonothioic acid (VX) pit was about $30 \mathrm{~m}$ (100 ft) long, and the dichlorodiethyl sulfide (mustard) pit was about $45 \mathrm{~m}$ (150 ft) long. The liquid smoke pit occupied an area of about $2.2 \mathrm{~m}^{2}\left(24 \mathrm{ft}^{2}\right)$. In this pit, titanium tetrachloride (FM) and sulfur trioxidechlorosulfonic acid (FS) were dumped on the ground and allowed to vaporize. High explosives were also detonated along the southeastern edge of the TBP area. 


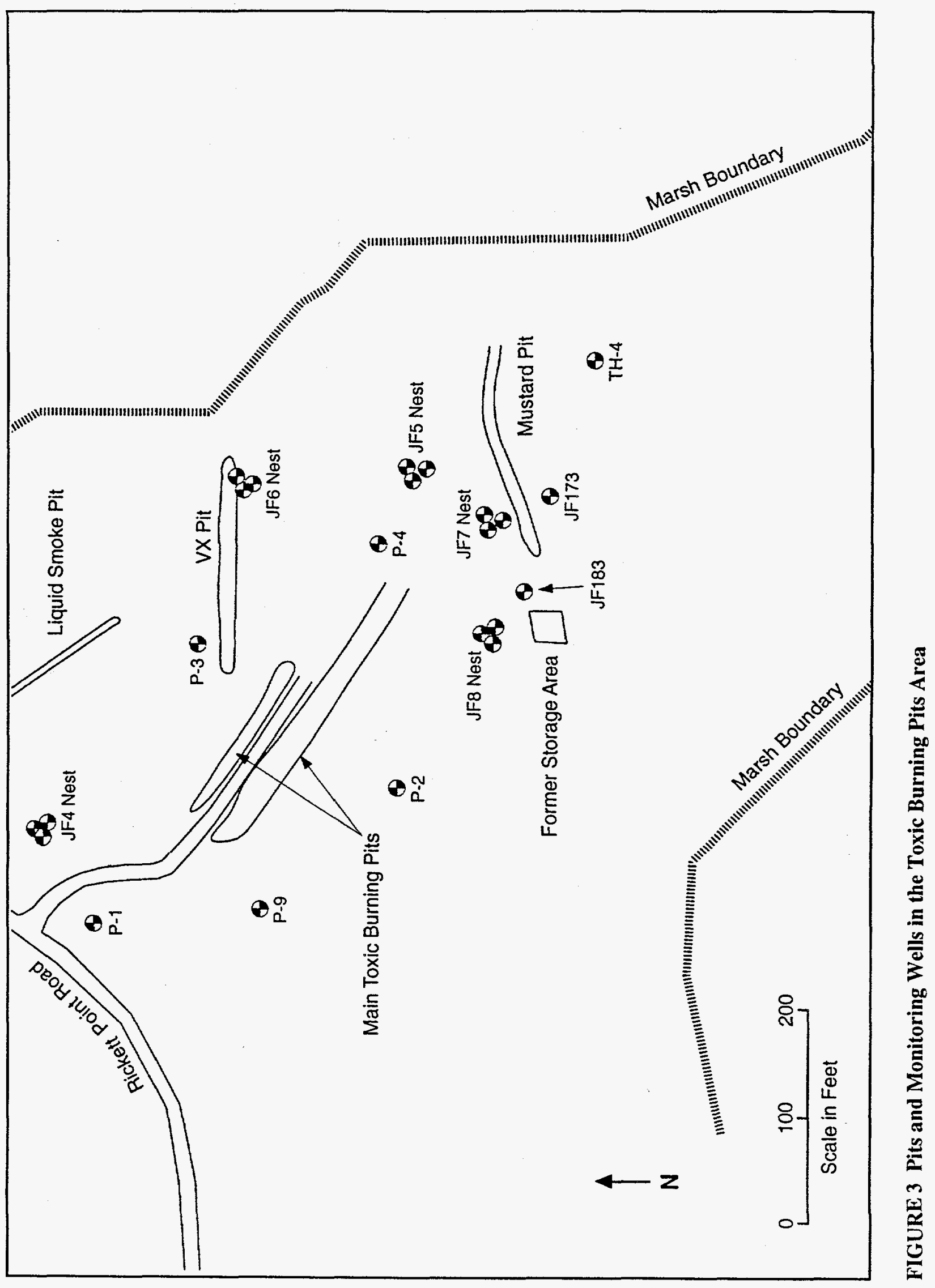


Recent thorough investigations by Argonne National Laboratory (ANL) of historical aerial photographs of J-Field and geophysical surveys provide fairly accurate locations of the liquid smoke, VX, and mustard pits relative to the two main pits (Yuen 1994). The study also indicates a former storage area along the south edge of the area (Figure 3). This information aided in assessing the distribution of subsurface contaminants at the TBP area. However, because of the poorly documented disposal history at the site, it is possible that other, unknown, waste disposal locations exist. 


\section{GEOLOGIC AND HYDROLOGIC SITE CHARACTERIZATION}

\subsection{SURFACE WATER}

On-site surface water features include marshes, a pond, and two unnamed streams. The pond and marsh along the southern shore are separated from Chesapeake Bay by a sandy beach.

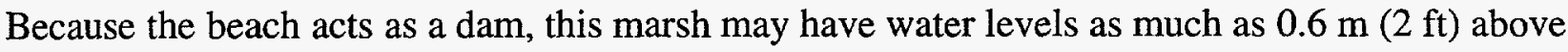
high tide (Hughes 1993c). The large pond in this marsh has a depth that fluctuates between about $1 \mathrm{~m}(3 \mathrm{ft}$ ) in the spring to about $0.3 \mathrm{~m}(1 \mathrm{ft}$ ) in the summer (Hughes 1995). Other large marshes are located along J-Field's eastern and western shores. Water levels in these marshes vary according to tidal influence (Hughes 1995).

The two streams are within the marshes along the eastern coast and are affected by tides. Their discharge is minimal except during storms (Hughes 1993c).

The coastline varies from gravelly beaches to sharp cliffs. Gabions protect a portion of the cliff along the coast west of the TBP area, where the shoreline has eroded $60 \mathrm{~m}(200 \mathrm{ft})$ in the last several decades.

A tidal measuring station is located on APG's Pooles Island, which is about $1.6 \mathrm{~km}(1 \mathrm{mi})$ southeast of J-Field. The difference between the mean high tide and the mean low tide is $0.36 \mathrm{~m}$ (1.2 ft) (National Oceanic and Atmospheric Administration 1993). Hughes (1995) reported that the average level of the surrounding estuaries with respect to MSL at Pooles Island is $0.27 \mathrm{~m}(0.9 \mathrm{ft})$.

The depth of water in the Gunpowder River and the Chesapeake Bay proper within $0.8 \mathrm{~km}$

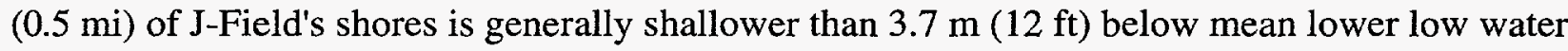
(National Oceanic and Atmospheric Administration 1993). In a location where two tides occur each day, mean lower low water refers to the average of each day's lower tidal elevation.

The southern marsh and other surface water bodies are expected to receive part of their input budget as groundwater discharge from the land portions of J-Field. Possible evidence for this interaction is in the form of thermal imagery performed by the U.S. Geological Survey (Weston 1994).

\subsection{AQUIFER RECHARGE}

The average annual precipitation in Harford County is $116.4 \mathrm{~cm}$ (45.83 in.) (Smith and Matthews 1975). The runoff component of precipitation at J-Field is received by marshes or the two streams. Because of the low infiltration capacity of the soils, water also collects in on-site wooded areas during wet periods (Hughes 1993c). 
The surficial aquifer receives most of its recharge by infiltration of precipitation. However, during periods of high evapotranspiration, water levels in wells may be slightly lower than the bay level (Hughes 1993c). A flow reversal may take place during these intervals, and water from the tidal estuaries provides recharge to the aquifer.

Previous U.S. Geological Survey (USGS) modeling and field studies on the Gunpowder Neck Peninsula show a range of recharge values. Vroblesky et al. (1989) used $34.3 \mathrm{~cm} / \mathrm{yr}$ (13.5 in./yr) in areas of sandy soil and $30.5 \mathrm{~cm} / \mathrm{yr}(12.0 \mathrm{in.} / \mathrm{yr})$ in areas of clayey soil. Another modeling study also assumed $34.3 \mathrm{~cm} / \mathrm{yr}$ (13.5 in./yr) (Lorah and Clark 1995). A project focused on J-Field assigned a uniform recharge of $43 \mathrm{~cm} / \mathrm{yr}(17 \mathrm{in} . / \mathrm{yr})$ on the basis of the response of well hydrographs to precipitation events (Hughes 1995). A drawback to this method is the potential for erroneously high estimates resulting from air entrapment (Freeze and Cherry 1979). A Maryland Geological Survey model of portions of the coastal plain portion of Harford County fixed recharge at $46 \mathrm{~cm} / \mathrm{yr}$ (18 in./yr) (Drummond and Blomquist 1993).

\subsection{SOILS}

Mapping of site soils could indicate areal variation of infiltration. In the most recent Harford County soil survey (Smith and Matthews 1975), the APG was not mapped. A previous survey by Perkins and Winant (1927), however, includes the APG. Their map indicates that the surface of J-Field consists of fairly equal areas of Elkton silt loam, Sassafras loam, and tidal marshes, with minor areas of Sassafras silt loam. Smith and Matthews (1975) describe the Elkton as slowly permeable. The Sassafras soils are moderately permeable. The tidal marsh soil is sandy to clayey with peat or muck.

Because the soil mapping was not performed with a high degree of accuracy, and because the J-Field surficial soils have reasonably similar permeabilities, the recharge assigned to the model was not varied areally.

\subsection{HYDROGEOLOGY}

J-Field's stratigraphy is described by Hughes (1993c) as Pleistocene sediments of the Talbot Formation over Cretaceous sediments of the Patapsco Formation of the Potomac Group. The Pleistocene deposits are divided into three hydrogeologic units: a surficial, unconfined aquifer of interbedded sand, clay, and silt; a confining unit of sandy and silty clay; and a confined sand and gravel aquifer. Figure 4 shows a conceptual model of the Pleistocene stratigraphy of J-Field. 


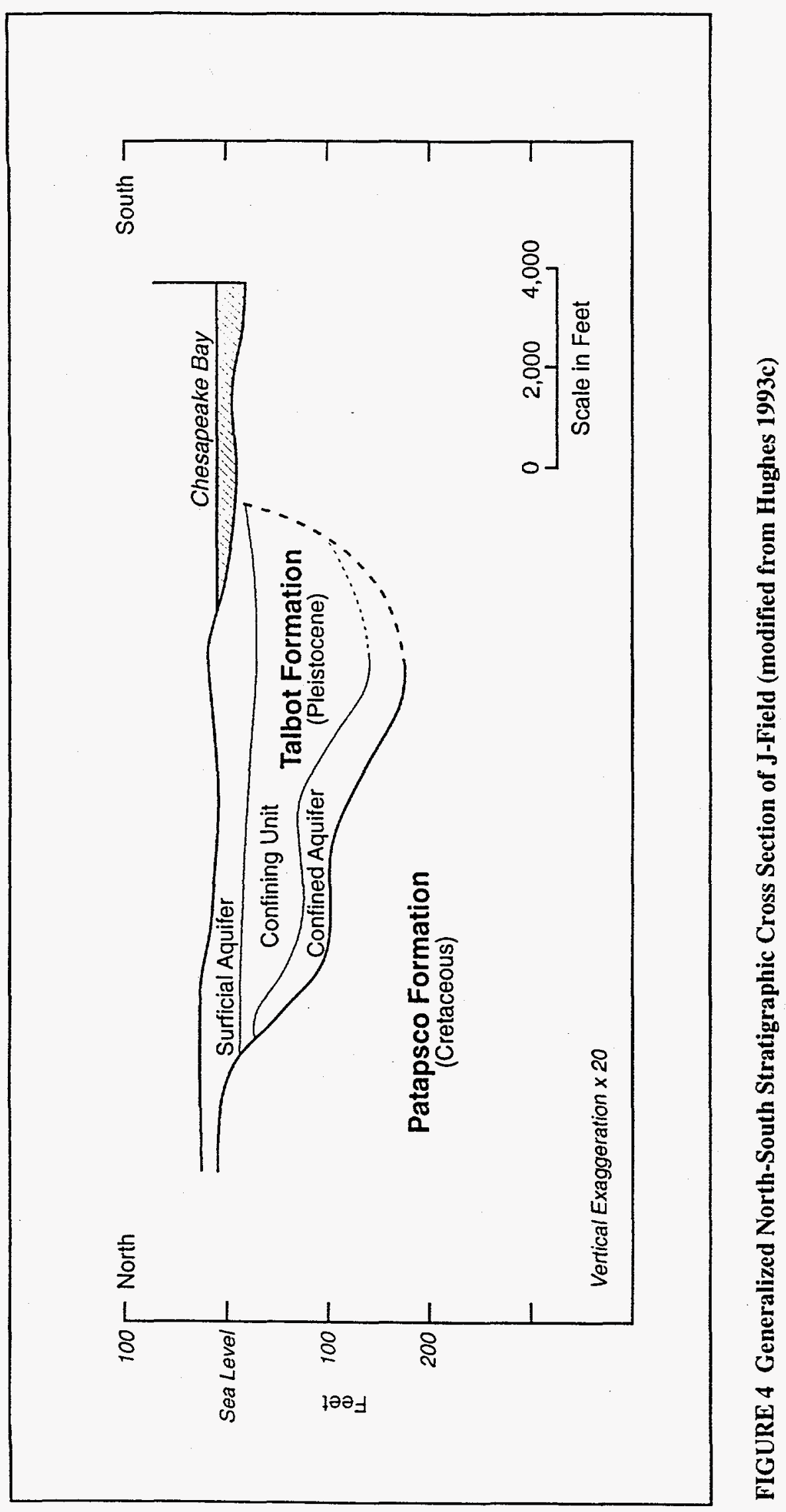


The deeper Talbot deposits fill a southwest-trending paleochannel eroded into the Patapsco Formation. In the region, Pleistocene paleochannels are common (Kerhin et al. 1988). Similar features have been identified at other APG study areas (Oliveros and Vroblesky 1989; Vroblesky et al. 1989; Lorah and Clark 1995). Hughes (1991, 1992, 1993c) performed a marine seismic survey around the J-Field peninsula to determine the offshore extent of the geologic units. The data suggest that the confining unit and the confined aquifer pinch out against the sides of the paleochannel. By correlating the seismic results with the stratigraphic data from seven deep borings, the approximate trends of the pinch-outs were determined for the confining unit and the confined aquifer.

\subsubsection{Available Data}

Several recent investigations provide subsurface data for J-Field in the form of stratigraphic logs and groundwater samples. Most of the monitoring well and borehole locations are presented in Hughes (1993c). Figure 3 shows the wells near the TBP area.

The U.S. Army Toxic and Hazardous Materials Agency (USATHAMA) installed 11 on-site monitoring wells in 1977-1978 (Hughes 1993c). These TH-series wells are screened in the surficial

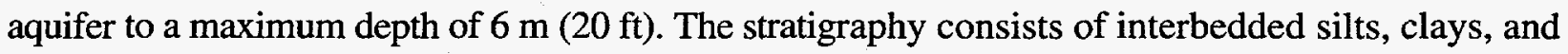
sands (Nemeth et al. 1983). One well, TH-9, was lost as the shore west of the TBP area eroded.

Princeton Aqua Science (1984) installed nine monitoring wells that are also screened in the

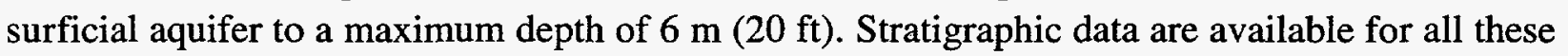
P-series wells except P9. The descriptions indicate very fine to medium sands and silts; thicknesses range from 1 to $4.5 \mathrm{~m}$ ( 3 to $15 \mathrm{ft}$ ).

The USGS collected subsurface data by drilling seven exploratory borings to depths of

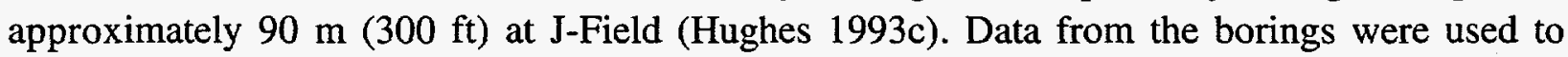
characterize the subsurface of J-Field through the Pleistocene deposits into the underlying Cretaceous materials. Two of these borings were converted to monitoring wells and are referred to as JF1 and JF2. The wells are screened in permeable portions of the Potomac sediments. The stratigraphic interpretations for these borings were based on examinations of the drill cuttings, split spoon samples at inferred lithologic changes, and geophysical logs.

The USGS also installed 12 monitoring well nests of three wells each to address contamination in the three Pleistocene hydrogeologic units (Hughes 1993c). These nests are located in the TBP area and around other AOCs in the southwestern and western portions of J-Field. Logging of the stratigraphy at these wells was based on continuous sampling. The well screens are generally 0.9 or $1.5 \mathrm{~m} \mathrm{(} 3$ or $5 \mathrm{ft}$ ) long. The shallow wells in the surficial aquifer have a maximum depth of 5.5 to $10.7 \mathrm{~m}$ (18 to $35 \mathrm{ft}$ ). The intermediate wells in the confining unit are 15.8 to $25.9 \mathrm{~m}$ (52 to $85 \mathrm{ft}$ ) deep. The deep wells are ideally in the confined aquifer, but some are finished in 
fine-grained sediments that may be considered part of the confining unit. These wells range in total depth from 21.6 to $38.1 \mathrm{~m}$ ( 71 to $125 \mathrm{ft}$ ).

Hughes (1993c) performed slug tests on 10 monitoring wells screened in the Pleistocene units and on one completed in the Cretaceous. The data were analyzed by the methods of both Hvorslev (1951) and Cooper et al. (1967) to determine hydraulic conductivity values. Hughes (1993c) did not calculate storativities using the Cooper method.

Four additional shallow monitoring wells were installed in 1992 by the USGS to examine portions of J-Field lacking groundwater data (Hughes 1993b). These wells reach depths of $3.7 \mathrm{~m}$ $(12 \mathrm{ft})$.

ANL installed Well 173 southeast of the TBP area to monitor for dense nonaqueous phase liquids at the base of the surficial aquifer. The screened interval is 7.9 to $9.4 \mathrm{~m} \mathrm{(26} \mathrm{to} 31 \mathrm{ft}$ ) deep (Patton 1994).

In the spring of 1994, the USGS installed several piezometers between the TBP area and the marsh to study groundwater and surface water interaction.

In 1994, the U.S. Army Corps of Engineers installed Well 183, an overdesigned extraction well with a $34.6-\mathrm{cm}(13.625-\mathrm{in}$.) diameter hole. The well is fully screened across the thickness of the surficial aquifer. ERM (1995) performed a pump test of the well to obtain aquifer parameters.

Several groundwater modeling studies have been completed on the Gunpowder Neck Peninsula. These studies aid in understanding aspects of groundwater flow local to APG. Vroblesky et al. (1989) investigated the flow system at O-Field, which is over $3 \mathrm{~km} \mathrm{(2} \mathrm{mi)} \mathrm{north} \mathrm{of} \mathrm{J-Field.}$ Lorah and Clark (1995) studied the Canal Creek area, which is $8 \mathrm{~km}$ (5 mi) north of J-Field. Both of these projects included drilling and aquifer testing, and both of these sites share some hydrogeologic similarities with J-Field. The USGS recently completed a detailed modeling study of groundwater flow at J-Field (Hughes 1995).

\subsubsection{Surficial Aquifer}

The surficial aquifer consists of medium- to fine-grained sand with interbedded clay (Hughes 1993c). The sand is generally red to gray in color; the clay is dark to light gray. The sandy facies are commonly silty or clayey. Hughes suggests that these sediments were deposited in an estuarine or marginal marine system during a period of higher sea level. A 3-m (10-ft) high vertical exposure of this unit is visible along the coast west of the TBP area. Here the stratigraphy is mainly reddish silt with fine sand. A $0.3-\mathrm{m}$ (1-ft) clay is also present. Along the $15-\mathrm{m}(50-\mathrm{ft})$ long cliff, the depositional units appear to be continuous. 
The total thickness of this unit at J-Field is 9 to $12 \mathrm{~m} \mathrm{(30} \mathrm{to} 40 \mathrm{ft}$ ). The hydraulic conductivity $(\mathrm{K})$ of this aquifer was measured using slug test techniques at three monitoring wells: JF33, JF93, and JF113 (Table 1). The three slug-tested wells are in the southwestern portion of $\mathrm{J}$-Field but not in the immediate vicinity of the TBP area. The hydraulic conductivity values range from $1.0 \times 10^{-4}$ to $3.7 \times 10^{-4} \mathrm{~cm} / \mathrm{s}(0.29$ to $1.04 \mathrm{ft} / \mathrm{d})$, with a median value of $2.4 \times 10^{-4} \mathrm{~cm} / \mathrm{s}$ $(0.69 \mathrm{ft} / \mathrm{d})$. These values are typical of silty sand or silt (Freeze and Cherry 1979). Because of the problems inherent to slug testing of wells, this aquifer testing method often underestimates the horizontal hydraulic conductivity $\left(\mathrm{K}_{\mathrm{H}}\right)$ (Bradbury and Muldoon 1990; Hughes 1993a). During calibration of a J-Field model, a value of $2.8 \times 10^{-3} \mathrm{~cm} / \mathrm{s}(8 \mathrm{ft} / \mathrm{d}$ ) was assigned to this unit (Hughes 1995). This value is within the range of values for a silty to clean sand (Freeze and Cherry 1979).

Aquifer parameters calculated from the pump test at Well 183 include a $\mathrm{K}_{\mathrm{H}}$ of $1.5 \times 10^{-3} \mathrm{~cm} / \mathrm{s}(4.3 \mathrm{ft} / \mathrm{d})$ during the pumping phase and $2.2 \times 10^{-3} \mathrm{~cm} / \mathrm{s}(6.3 \mathrm{ft} / \mathrm{d})$ during the recovery phase (Quinn 1995). Pump tests generally result in more representative aquifer parameters than slug tests because a greater volume of the aquifer is analyzed.

TABLE 1 Slug Test Results

\begin{tabular}{|c|c|c|c|c|c|}
\hline $\begin{array}{l}\text { Well } \\
\text { No. }\end{array}$ & $\begin{array}{c}\text { Screen } \\
\text { Length } \\
(\mathrm{ft})\end{array}$ & $\begin{array}{c}\text { Screen } \\
\text { Opening } \\
\text { (in.) }\end{array}$ & $\begin{array}{c}\text { Hydraulic } \\
\text { Conductivity } \\
\text { (Hvorslev } \\
\text { method) } \\
\text { (ft/d) }\end{array}$ & $\begin{array}{c}\text { Hydraulic } \\
\text { Conductivity } \\
\text { (Cooper } \\
\text { method) } \\
(\mathrm{ft} / \mathrm{d})\end{array}$ & $\begin{array}{c}\text { Hydro- } \\
\text { stratigraphic } \\
\text { Unit }\end{array}$ \\
\hline JF33 & 5 & 0.001 & 0.70 & 1.04 & Surficial \\
\hline JF93 & 5 & 0.01 & 0.29 & $-^{\mathbf{a}}$ & Aquifer \\
\hline JF113 & 3 & 0.01 & 0.69 & 0.58 & \multirow{4}{*}{$\begin{array}{c}\text { Confining } \\
\text { Unit }\end{array}$} \\
\hline JF32 & 5 & 0.001 & 0.05 & 0.09 & \\
\hline $\mathrm{JF42}$ & 5 & 0.06 & $<0.01$ & 0.02 & \\
\hline JF92 & 5 & 0.06 & 0.20 & - & \\
\hline JF31 & 5 & 0.001 & 13.6 & 51.8 & \multirow{4}{*}{$\begin{array}{c}\text { Confined } \\
\text { Aquifer }\end{array}$} \\
\hline JF41 & 5 & 0.01 & 272 & 932 & \\
\hline JF91 & 5 & 0.001 & 3.16 & 7.41 & \\
\hline JF111 & 5 & 0.01 & 111 & 508 & \\
\hline JF2 & 5 & 0.01 & 0.61 & 0.06 & Cretaceous \\
\hline
\end{tabular}

a $-=$ not determined.

Source: Hughes (1993c). 
A storage term of 0.0066 was also determined during the pump test of Well 183 (Quinn 1995). This value is approximately three orders of magnitude less than what would be expected for the specific yield of an unconfined aquifer. It may suggest semiconfining effects because of the interbedded nature of the surficial aquifer sediments, or it may result from the time-dependency of the specific yield term (Nwankwor et al. 1992).

Perhaps the most important knowledge gained during the step drawdown testing of Well 183 is that despite the design of the well, it could not provide a yield as low as $0.12 \mathrm{~L} / \mathrm{s}$ ( $2 \mathrm{gal} / \mathrm{min}$ ). A yield of $0.06 \mathrm{~L} / \mathrm{s}(1 \mathrm{gal} / \mathrm{min}$ ) was sustained during the constant rate test. This information is critical in the design of a groundwater extraction well network.

Despite the available data, the permeability of the surficial aquifer is uncertain at the TBP area and throughout most of J-Field. Any measurement is highly spatially-dependent because of the location-specific stratigraphy, well construction factors, and the depth interval measured by the well screen. Hydraulic conductivity measurements were not available for the surficial aquifer elsewhere in J-Field. However, Vroblesky et al. (1989) performed slug tests for the surficial aquifer at O-Field and reported hydraulic conductivity measurements of $2.1 \times 10^{-2}$ to $6.9 \times 10^{-2} \mathrm{~cm} / \mathrm{s}(63 \mathrm{to} 202 \mathrm{ft} / \mathrm{d})$ in a localized area of high permeability. In the remainder of the site, slug tests indicated lower hydraulic conductivity values in the range of $1.7 \times 10^{-3}$ to $2.6 \times 10^{-2} \mathrm{~cm} / \mathrm{s}(5$ to $75 \mathrm{ft} / \mathrm{d})$. Lorah and Clark (1995) calibrated their model with conductivities of $1.0 \times 10^{-2}$ to $4.2 \times 10^{-2} \mathrm{~cm} / \mathrm{s}(29$ to $120 \mathrm{ft} / \mathrm{d}$ ) in the surficial aquifer. The elevation and surficial soils in those areas are similar to those at J-Field (Perkins and Winant 1927), so it is possible that portions of the subsurface of J-Field may also have higher permeabilities. However, the permeability of the surficial aquifer is expected to vary over several orders of magnitude laterally and vertically because of the arrangement of interbedded facies.

Continuous head recordings are available from the USGS for the 1993 water year for two surficial aquifer wells in the TBP area (JF63 and JF43). The head in these wells is over $2 \mathrm{~m}$ ( $6 \mathrm{ft}$ )

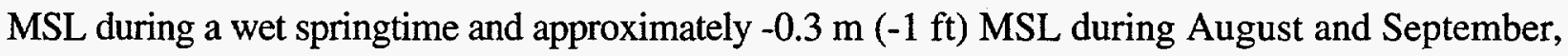
when high evapotranspiration rates prevail. The data showed no daily tidal fluctuations, suggesting that the distance from the shore to the TBP area is sufficient to negate tidal influence.

Under Maryland Code of Regulations 26.08.02.09, the surficial aquifer at J-Field is categorized as a Class III aquifer on the basis of hydraulic conductivity less than $4.7 \times 10^{-3} \mathrm{~cm} / \mathrm{s}$ $\left(100 \mathrm{gal} / \mathrm{d} / \mathrm{ft}^{2}\right.$ or $\left.13.3 \mathrm{ft} / \mathrm{d}\right)$. However, away from the pump test location, the aquifer may have a hydraulic conductivity and transmissivity sufficiently high to meet Class II criteria. 


\subsubsection{Confining Unit}

The confining unit contains silty and sandy clay with shell fragments and varying amounts of organic matter. The clay is dark gray or olive gray in color. Hughes (1993c) interprets the sediment to be an estuarine deposit. The upper surface of this unit ranges in depth from about $7.6 \mathrm{~m}$

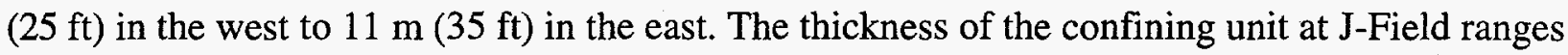

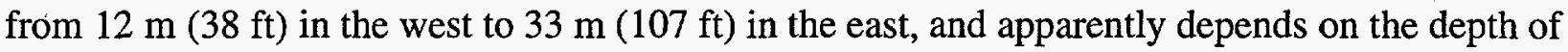
the paleochannel's erosion into the Potomac group. Slug tests performed on three wells completed in this unit (JF32, JF42, JF92) yielded hydraulic conductivity values ranging from $<3 \times 10^{-6}$ to $7.0 \times 10^{-5} \mathrm{~cm} / \mathrm{s}(<0.01$ to $0.20 \mathrm{ft} / \mathrm{d})$, with a median of $1.8 \times 10^{-5} \mathrm{~cm} / \mathrm{s}(0.05 \mathrm{ft} / \mathrm{d})($ Table 1$)$. These values fall into the typical range of fine-grained materials (Freeze and Cherry 1979). Because the slug test generally provides an estimate of $\mathrm{K}_{\mathrm{H}}$, the vertical hydraulic conductivity $\left(\mathrm{K}_{\mathrm{V}}\right)$ may be much less. A K $\mathrm{V}_{\mathrm{V}}$ value of $1.8 \times 10^{-6} \mathrm{~cm} / \mathrm{s}\left(5 \times 10^{-3} \mathrm{ft} / \mathrm{d}\right)$ used in a J-Field groundwater model by Hughes (1995) compares favorably with that of Vroblesky et al. (1989), who modeled a nearby clay-filled estuarine paleochannel with a $\mathrm{K}_{\mathrm{v}}$ of $6.8 \times 10^{-8}\left(2 \times 10^{-4} \mathrm{ft} / \mathrm{d}\right)$. Hughes $(1993 \mathrm{c})$ did not observe tidal effects in wells screened in the confining unit.

\subsubsection{Confined Aquifer}

The confined aquifer consists of gravelly sand with some clay and clayey sand. The top of

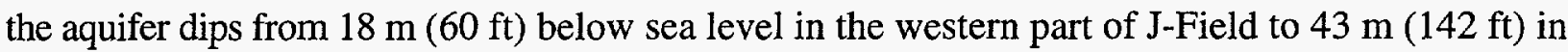
the southeast. The full thickness of the confined aquifer is penetrated by the seven exploratory borings. Its thickness ranges from $14 \mathrm{~m}(45 \mathrm{ft})$ in the western portion of the peninsula to $4.6 \mathrm{~m}$ $(15 \mathrm{ft})$ in the east.

The confined aquifer is a fluvial deposit that blankets the bottom of a paleochannel identified by marine seismic and exploratory borings. Slug tests were performed in four wells screened in the confined aquifer: JF31, JF41, JF91, and JF111 (Hughes 1993c). Hydraulic conductivity values determined from two wells completed in permeable portions of the aquifer were $3.9 \times 10^{-2}$ and $3.2 \times 10^{-1} \mathrm{~cm} / \mathrm{s}(110$ and $930 \mathrm{ft} / \mathrm{d})$, with a median of $1.3 \times 10^{-1} \mathrm{~cm} / \mathrm{s}(390 \mathrm{ft} / \mathrm{d})$ (Table 1). Hydraulic conductivity values determined for two other wells screened in fine-grained zones were $1.1 \times 10^{-3}$ and $1.8 \times 10^{-2} \mathrm{~cm} / \mathrm{s}(3.2$ and $52 \mathrm{ft} / \mathrm{d})$, with a median of $3.9 \times 10^{-3} \mathrm{~cm} / \mathrm{s}$ $(11 \mathrm{ft} / \mathrm{d})$.

Continuous head data from the USGS for the confined aquifer exhibit a strong tidal influence; heads fluctuate over a range of approximately $0.23 \mathrm{~m}(0.75 \mathrm{ft})$. The amplitudes of the fluctuations show a high degree of similarity independent of distance from the shoreline. The head changes are therefore attributed to tidal loading on the confined aquifer. 


\subsubsection{Cretaceous Sediments}

The Cretaceous Patapsco Formation sediments beneath J-Field are alluvial deposits of interbedded fine-grained sand and massive clay (Hughes 1993c). USGS drilling logs differentiate the Cretaceous clays from Pleistocene clays by color. Rather than the dark and olive gray of the confining unit, the Patapsco clays vary among reddish brown, light gray, white, light red, and olive yellow. The top of the Cretaceous sediments dips from $32 \mathrm{~m}(105 \mathrm{ft})$ below sea level in eastern J-Field to $48 \mathrm{~m}(157 \mathrm{ft}$ ) in the western part (Hughes 1993c). Interpretation of gamma logs of the exploratory boreholes suggests that the thicknesses of the sands range from 0.6 to $9 \mathrm{~m}$ ( 2 to $30 \mathrm{ft}$ ), and the thicknesses of the clays range from 1.5 to $14 \mathrm{~m}(5$ to $45 \mathrm{ft}$ ). Cross sections of the stratigraphy suggest that the various lenses are laterally highly discontinuous. The Cretaceous

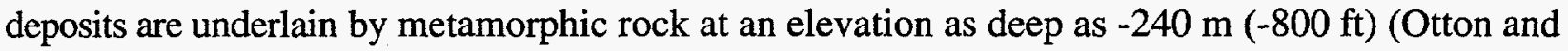
Mandle 1984).

\subsubsection{General Groundwater Flow}

Field measurements of heads at J-Field indicate that groundwater flow is generally from topographic highs to marsh and estuary discharge areas (Hughes 1993c). In the TBP area, the water table has a local high in the area between the two main pits and the Prototype Building. No pumping stresses are imposed on any Talbot aquifers in the vicinity of J-Field. In fact, the nearest pumping wells are $6 \mathrm{~km}$ (4 mi) away, across the Gunpowder River (Hughes 1993c).

A comparison of the heads of wells screened in the three Pleistocene hydrogeologic units indicated a downward gradient and suggests leakage from the surficial aquifer into the confining unit and confined aquifer (Hughes 1993c). Below wetlands and estuaries, however, flow is assumed to be vertically upward, as groundwater flows from the deeper units to the discharge areas. The vertical head gradient within the surficial aquifer currently cannot be determined because only one well is screened in the surficial aquifer at each USGS well nest.

Hughes (1993c) describes the head distribution pattern in the confining unit and the confined aquifer as being generally similar to the pattern in the surficial aquifer. A low lateral head gradient was observed, so lateral flow is minimal. Discharge is believed to occur through the confining unit into the estuaries. During dry periods, flow reversals take place, as the heads in the surficial aquifer fall slightly below those in the confined aquifer. 


\section{GROUNDWATER FLOW MODEL}

\subsection{CONCEPTUAL GROUNDWATER MODEL}

Field data and prior groundwater modeling studies of the APG suggest an initial hydrogeologic conceptual model similar to that of Hughes (1993c). Hydrostratigraphic units were modeled using a three-layer system. Recharge infiltrates the surficial aquifer, which is composed of poorly sorted sands interbedded with clay and silt. Underlying this aquifer is a clay confining unit, and below the clay is a sandy confined aquifer. The hydrogeologic units have contact surfaces that vary in elevation and, therefore, affect the saturated thickness of the surficial aquifer, the vertical conductance of the confining unit, and the transmissivity of the confined aquifer. Marine seismic results aid in delineating lateral geologic boundaries.

The present model is similar in many respects to the study by Hughes (1995), especially in many of the aquifer parameters and the extent of the modeling domain. The Hughes model was useful in providing a general understanding of the flow system and parameter sensitivity. However, the current model is highly focused on the TBP area, and, therefore, has a much finer grid resolution in the vicinity of the pits. Because of recently acquired field data at Well JF183, the current model should be regarded as more accurate. The use of optimization techniques in the design of a containment well system is the most important improvement over the previous model. In addition, the current model is calibrated to data available not only for the surficial aquifer but also for the confined aquifer.

\subsection{MODEL SELECTION}

Because it has many capabilities and supports several other programs with useful applications to the J-Field site, the numerical model selected for this study was the finite-difference USGS groundwater flow model Modflow (McDonald and Harbaugh 1988).

A code capable of three-dimensional modeling was required to investigate the flow system at J-Field. Modflow allows modeling of hydrogeologic flow systems in three dimensions. The program's versatility includes modeling of aquifer recharge, drains, heterogeneities, pumping wells, varying surfaces of hydrostratigraphic units, and different types of boundary conditions.

Grid design and input of aquifer parameters and boundary conditions were facilitated with the graphical preprocessor ModelCad (Geraghty and Miller, Inc. 1993). ModelCad allows the user to design a groundwater model over a cad basemap of the study area. Boundary conditions, aquifer properties, grid design, and other model features are all handled by ModelCad. Input files may be generated for Modflow. ModelCad also allows the user to visualize changes as a model is adapted 
for different situations (e.g., changes in grid design to address a different portion of the study area). The program can perform inverse distance squared interpolation of randomly spaced data to assign aquifer property values to model cells. In three-dimensional models, Modflow requires cell-by-cell values for vertical conductance, which is a function of the $\mathrm{K}_{\mathrm{V}}$ and unit thickness. ModelCad automatically calculates the array of conductance values for each layer by requesting $\mathrm{K}_{\mathrm{V}}$ values. Sedimentary units typically exhibit a horizontal:vertical anisotropy, ranging up to 100:1 (Freeze and Cherry 1979). In this study, all vertical conductivities were assumed to be one-tenth of the horizontal values. This ratio is assumed to be reasonable and was assigned for each layer in each model run.

Converted head output from Modflow is graphically displayed with a Cad basemap in the program SitePlanner (ConSolve 1993). SitePlanner is a multipurpose, object-oriented database run on a Unix workstation that contours data using linear interpolation between data points. Because the head output data are essentially uniformly gridded, SitePlanner is well-suited for contouring the Modflow output.

\subsection{GRID DESIGN AND BOUNDARY CONDITIONS}

Two Cad maps were combined to produce a basemap suitable for this modeling project. A simple contour map with a $1.5-\mathrm{m}(5-\mathrm{ft})$ contour interval covers the whole J-Field peninsula. The map dates back to the 1960s and includes roads and the Prototype Building as reference points. A more recent map by Roy F. Weston, Inc. (1992) provides a detailed view of the TBP area, the Riot Control Pit, and the White Phosphorous Pit (WPP) areas, and includes contours, wells, roads, buildings, and more accurate present-day shorelines west of the TBP area and WPP. One problem with the maps is that the roads and Prototype Building do not match up perfectly. The distortion might result from projection errors associated with producing the peninsula contour map from an aerial photograph. Any errors are assumed to be minor. The maps were input to both SitePlanner and ModelCad using a state planar system.

A rectangular, variably spaced grid focused on the TBP area was designed to account for hydrologic factors at $\mathrm{J}$-Field. Figure 5 shows nodes representing the center of each finite-difference cell. In the vicinity of the TBP area the grid is the finest, with cells $7.6 \mathrm{~m} \times 7.6 \mathrm{~m}(25 \mathrm{ft} \times 25 \mathrm{ft})$ (Figure 6). This size is small relative to the dimensions of the various source areas within the TBP area and is small relative to the distances from the sources to the marsh boundaries. Therefore, the grid spacing provides an adequate resolution of the flow system in the area of interest. This finely gridded area is surrounded by a $351-\mathrm{m}(1,150-\mathrm{ft})$ transition zone in which cell dimensions successively increase by a factor of 1.2. Although the general rule of thumb for grid expansion allows for increases by a factor of 1.5 , the smaller value was used in this study to reduce problems associated with numerical dispersion, especially because of the dramatic contrast in hydraulic conductivities of the three model layers. Beyond the transition zone, cells measure $76 \mathrm{~m} \times 76 \mathrm{~m}$ $(250 \mathrm{ft} \times 250 \mathrm{ft})$, which is fine enough to match features such as distant marshes and shorelines. 


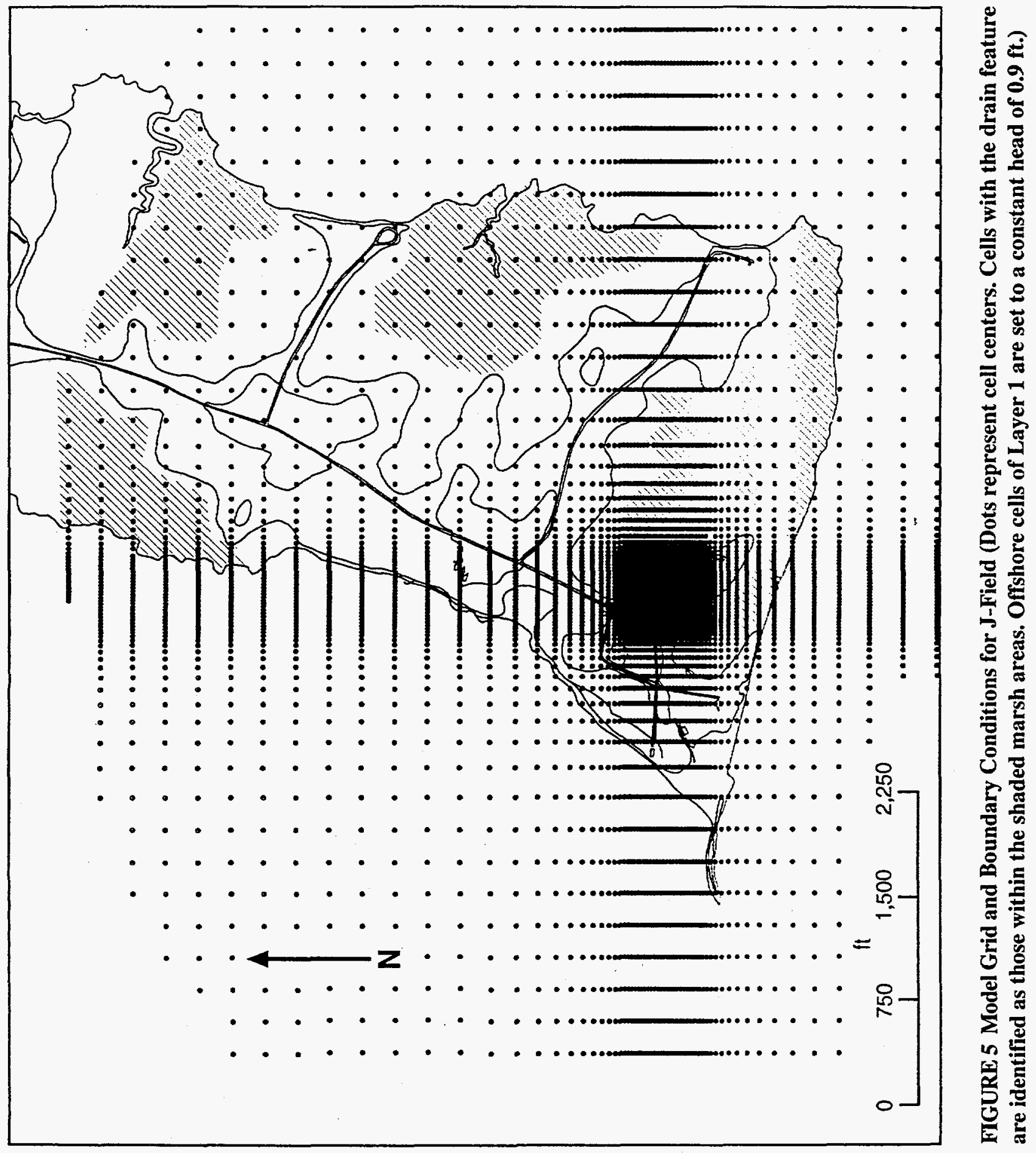




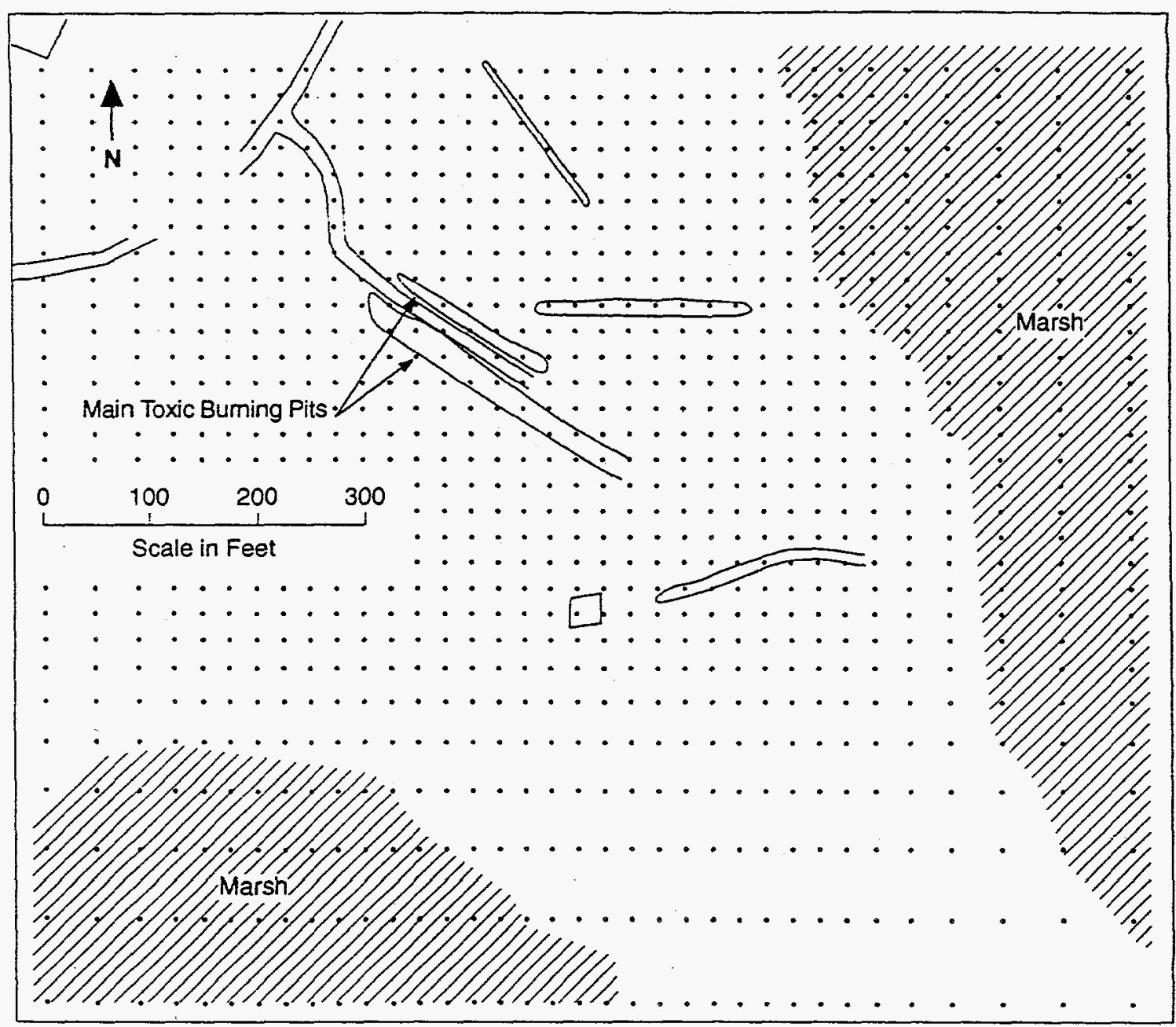

FIGURE 6 Model Grid and Boundary Conditions for the Toxic Burning Pits Area (Dots represent cell centers. Cells with the drain feature are identified as those within the shaded marsh areas.)

In layer 1 , offshore cells of the surficial aquifer were assigned a constant head of $0.27 \mathrm{~m}(0.9 \mathrm{ft})$ MSL, the average level of the bay (Hughes 1995). Fluctuations in bay level were assumed to have no effect in the steady-state model. The shoreline boundary was discretized on the basis of the Cad basemap dating from the 1960s. West of the TBP and WPP areas, the Roy F. Weston, Inc. (1992) map was used to delineate the present position of the eroding shore.

In the northern portion of the layer, a no-flow boundary was assigned trending northwestsoutheast through the centers of the extensive northern marshes (Figure 5). This transect represents a groundwater divide in the surficial aquifer and deeper units because of assumed discharge into the western and eastern marshes.

In layers 2 (confining unit) and 3 (confined aquifer), southeastern and northwestern portions of the modeling domain were made inactive (no-flow cells) by approximating the 
paleochannel boundaries shown in the marine seismic work of Hughes $(1991,1992,1993 \mathrm{c})$. The southwestern corner was made inactive at a distance far enough so that it has a negligible impact on the area of interest. The northern area has the same inactive extent of layer 1 , as the groundwater discharge patterns of the surficial aquifer are assumed to affect the deeper units in a similar fashion.

Marshes in layer 1 were modeled using the drain package of Modflow. Input parameters included an elevation below which the effect of the drain is inactive, and a drain conductance, which is normally determined during calibration (McDonald and Harbaugh 1988). Because water in the southern marsh is dammed by a sandy spit, it has a higher drain elevation than the other marshes on the peninsula. Marsh cells were assigned on the basis of a recent color-infrared photograph of J-Field (USGS 1989), which was taken during a wet period according to historical groundwater level data (James and Smigaj 1992). Figures 5 and 6 illustrate the distribution of the marsh cells.

The boundary conditions and properties assigned to model cells were assumed to provide a reasonably accurate representation of the conceptual model of J-Field, especially for the TBP area. In the main area of interest, the fine grid allows high-resolution modeling. At increased distances from the TBP area, potential errors resulting from discretization with the coarser grid were assumed to have a negligible effect on heads near the TBP area.

\subsection{GEOSTATISTICAL MODELING OF HYDROSTRATIGRAPHIC SURFACES}

The spatially varying upper and lower surfaces of the three hydrostratigraphic units affect the local saturated thickness of each unit. In order to include this varying transmissivity in the flow model, the contact elevations between the units were determined with geostatistical techniques. Geostatistical studies involve evaluating the spatial structure of data and using that information to calculate unbiased parameter estimates with minimal variance (Isaaks and Srivastava 1989).

Logs of wells and exploratory borings from Hughes (1993c) were evaluated, and contact depths were determined (Appendix A). Although the data are limited and most locations are in clusters, they provided an objective means of interpolating the contact surfaces. The estimates are best in the TBP area, where most of the data were collected to support site characterization.

Variogram modeling and kriging were performed using Geo-EAS (Englund and Sparks 1991). For the contact between the surficial aquifer and the confining unit, 16 data points were available. Although this was a fairly small data set for a two-dimensional study, a linear variogram approximately fit the data, with a nugget of $0 \mathrm{~m}^{2}\left(0 \mathrm{ft}^{2}\right)$ and a sill and range defined by a line through a sill of $4.6 \mathrm{~m}^{2}\left(50 \mathrm{ft}^{2}\right)$ and a range of $1,200 \mathrm{~m}(4,000 \mathrm{ft})$. For the contact between the confining unit and the confined aquifer, only 12 data points were available; for the contact between the confined aquifer and the Cretaceous sediments, only 7 data points were available. In these two cases, the variograms were very crude because of the small number of data pairs. 
Ordinary kriging runs were performed for each surface by using variogram parameters based on the analysis of the contact between the surficial aquifer and the confining unit. The uniform kriging grid had a resolution of $27.7 \mathrm{~m}(91 \mathrm{ft})$. The following procedure was followed for each of the three hydrostratigraphic surfaces. The raw data were added to the kriging output. The combined data file was brought into ModelCad, and an inverse distance squared method was implemented to determine an estimate for each cell in the nonuniform finite-difference grid. Figures 7 through 9 are views of the three contact surfaces. The contact elevation ranges from -11 to $-6.4 \mathrm{~m}(-35$ to $-21 \mathrm{ft}) \mathrm{MSL}$ for the base of the surficial aquifer, -43 to $-18 \mathrm{~m} \mathrm{(-140}$ to $-60 \mathrm{ft}) \mathrm{MSL}$ for the base of the confining unit, and -59 to $-31 \mathrm{~m}$ ( -193 to $-102 \mathrm{ft}$ ) MSL for the base of the confined aquifer.

\subsection{INITIAL INPUT PARAMETERS}

On the basis of prior modeling work by the USGS (Hughes 1995), recharge was initially specified uniformly at $43 \mathrm{~cm} / \mathrm{yr}(17 \mathrm{in} . / \mathrm{yr})$. The bay cells were modeled with constant heads of $0.27 \mathrm{~m}(0.9 \mathrm{ft})$. The $\mathrm{K}_{\mathrm{H}}$ of the surficial aquifer was set to $1.2 \times 10^{-3} \mathrm{~cm} / \mathrm{s}(5.3 \mathrm{ft} / \mathrm{d})$ on the basis of the analyses of the pumping and recovery phases of the pump test of Well JF183 (Quinn 1995).

The $K_{H}$ of the confining unit was initially set to $1.8 \times 10^{-5} \mathrm{~cm} / \mathrm{s}\left(5 \times 10^{-2} \mathrm{ft} / \mathrm{d}\right)$, as determined by Hughes (1995). The $\mathrm{K}_{\mathrm{H}}$ of the confined aquifer was set to $1.3 \times 10^{-1} \mathrm{~cm} / \mathrm{s}(390 \mathrm{ft} / \mathrm{d})$. The preprocessor ModelCad (Geraghty and Miller, Inc. 1993) calculated the vertical conductance between adjacent model layers on the basis of individual cell thickness and vertical conductivity, according to the method of McDonald and Harbaugh (1988). In model runs, vertical conductivities of each unit were consistently maintained at one-tenth of the corresponding horizontal values.

The drain package of Modflow was used to model the marshes. For the low-lying marshes along the eastern shore, the elevation specified was slightly above mean bay level, at $0.30 \mathrm{~m}(1 \mathrm{ft})$ MSL. The elevation of J-Field's southern marsh was set to $0.52 \mathrm{~m}(1.7 \mathrm{ft}) \mathrm{MSL}$, to approximate a yearly average for the feature. The conductance set for all marshes was $9.3 \mathrm{~m}^{2} / \mathrm{d}\left(100 \mathrm{ft}^{2} / \mathrm{d}\right)$.

\subsection{CALIBRATION}

The calibration of a groundwater flow model indicates how well the model's head output compares to target head values at measuring points. Calculations for calibration analyses may include the mean error, the mean absolute error, and the root mean squared error (RMSE). Of these, the RMSE is generally the best calibration indicator (Anderson and Woessner 1992). 


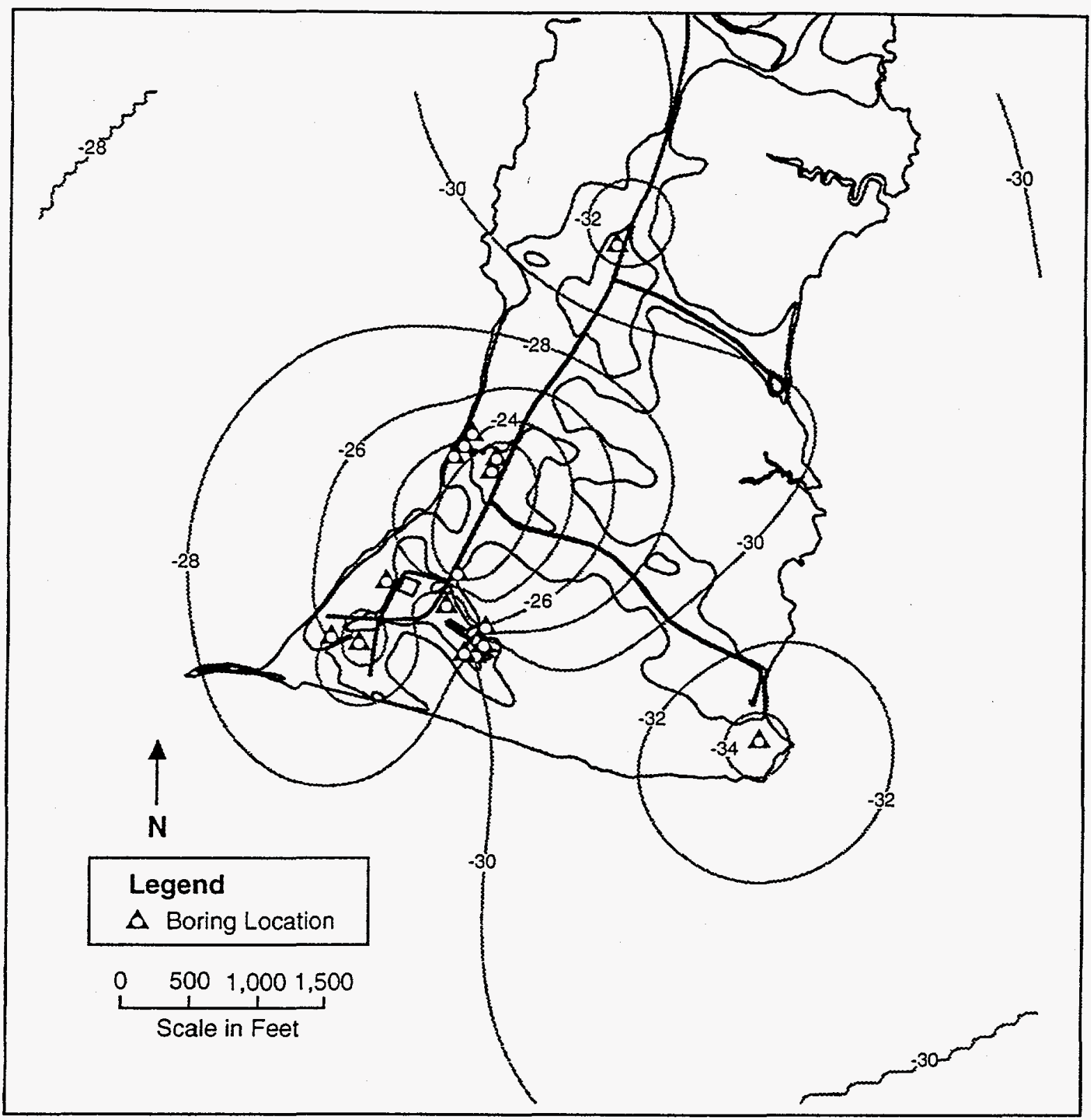

FIGURE 7 Elevation of Contact between the Surficial Aquifer and the Confining Unit (contour interval $=\mathbf{2} \mathrm{ft}$ )

Water levels in the monitoring wells in the surficial and confined aquifers provide suitable calibration targets. However, at J-Field, the fluctuations in heads measured in surficial aquifer monitoring wells may be over $2 \mathrm{~m}(6 \mathrm{ft})$, since they vary with season and with individual precipitation events. In addition, many of the surficial J-Field wells are close to the shore and are influenced by the tide. For this reason, the USGS hand measurements of water levels ("synoptic data") are of limited use. However, the USGS also maintains continuous water-level recorders in the wells of seven J-Field clusters. By calculating the arithmetic mean head values for the 1993 water year, reasonable calibration targets were determined for a steady-state simulation. The heads 


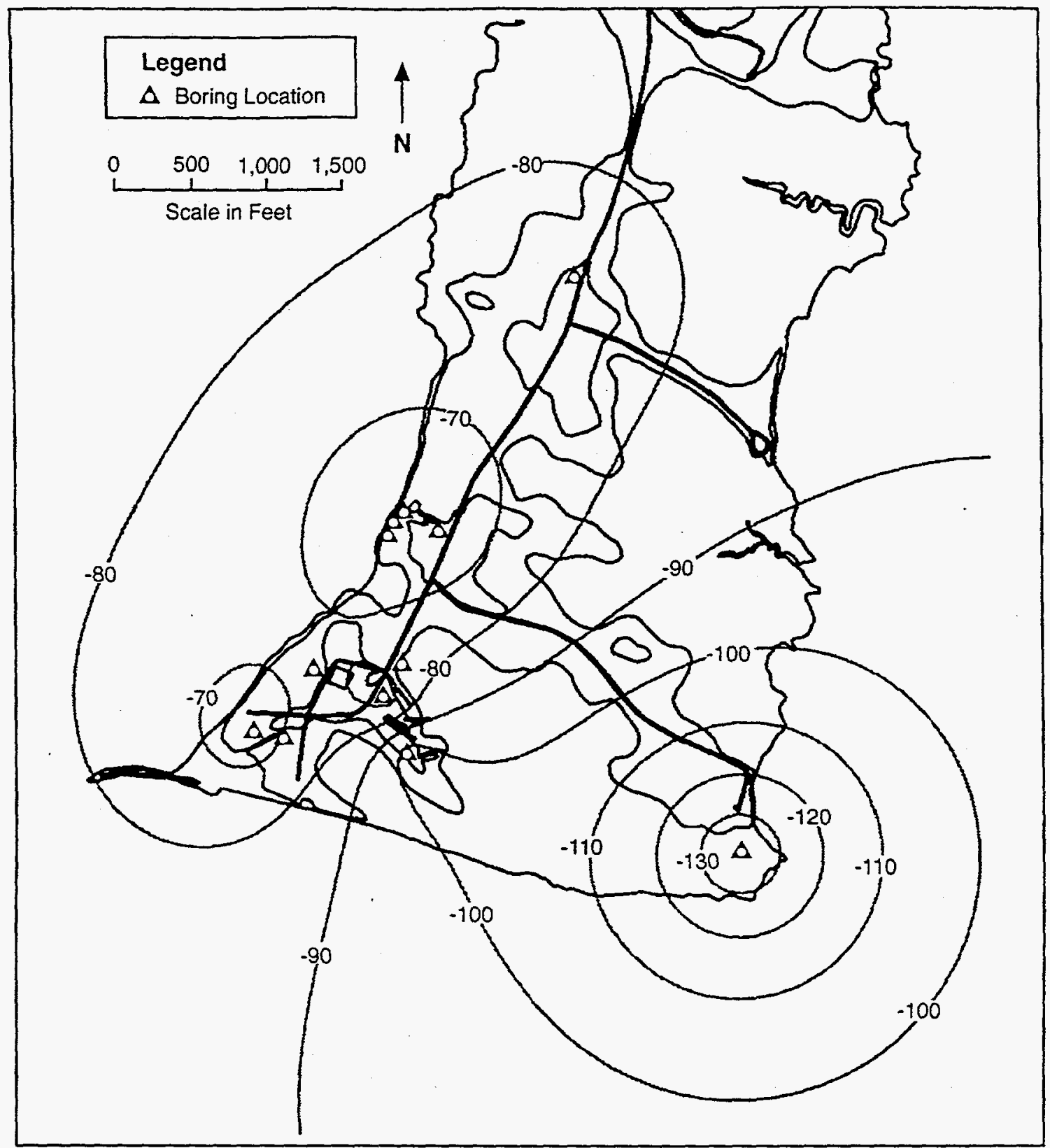

FIGURE 8 Elevation of Contact between the Confining Unit and the Confined Aquifer (contour interval $=\mathbf{1 0} \mathrm{ft}$ )

of these targets are dependent on distances from the shoreline and the marsh. The average head values are similar to the measurements from May 20, 1992, which were assumed to be representative steady-state heads and were used by Hughes (1995) as calibration targets.

The synoptic head measurements in the confined aquifer were of little use because they vary each day because of tidal loading. The continuous head data, however, provided mean values for the 1993 water year for use as steady-state calibration targets. This approach filtered out the 


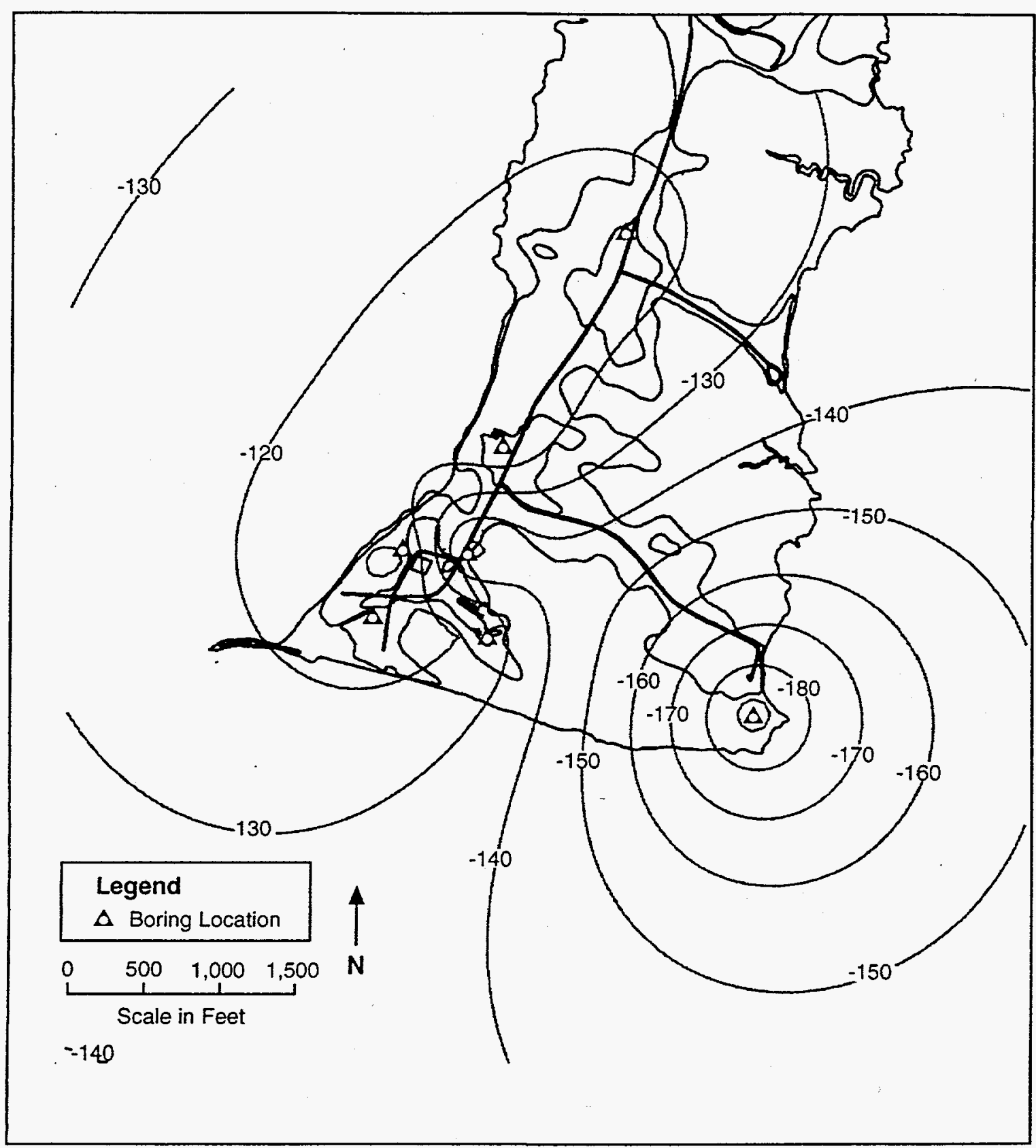

FIGURE 9 Elevation of Contact between the Confined Aquifer and the Cretaceous Sediments (contour interval $=\mathbf{1 0} \mathrm{ft}$ )

daily tidal fluctuations and resulted in calibration targets that primarily vary with distance from the shorelines.

Aquifer parameters that could be included in the calibration analysis included the hydraulic conductivities of the surficial aquifer, confining unit, and confined aquifer; the recharge to the surficial aquifer; and drain package parameters. Because a $K_{H}$ value had been specifically 
determined for the surficial aquifer at J-Field by a pump test, that parameter was held constant during calibration. Slug test data from Hughes (1993c) indicated a median $\mathrm{K}_{\mathrm{H}}$ or the confined aquifer of $1.3 \times 10^{-1} \mathrm{~cm} / \mathrm{s}(390 \mathrm{ft} / \mathrm{d}$ ) (Table 1$)$. This value was fixed during calibration because of the available data and because the model is relatively insensitive to this parameter. Drain parameters will be addressed in sensitivity analyses. Calibration involved checking the response of the model to the remaining parameters: the confining unit's hydraulic conductivity and the recharge.

Numerous calibration simulations were conducted; summaries of many of the runs are presented in Appendix B. For the ranges of values tested, the calibration runs indicated that when recharge is increased, the heads in the confined aquifer increase slightly, and the heads in the surficial aquifer increase significantly more. For increases in the hydraulic conductivity of the confining unit, the heads in the confined aquifer increase, and the heads in the surficial aquifer decrease very slightly.

The calibration process was somewhat subjective. Because of the proximity of all but two of the calibration target locations to the shoreline, discretization effects may have affected the simulated heads. For this reason, simulated heads matching those at clusters JF6 and JF4 (Figure 3) were considered most important.

Early calibration runs with a recharge of $43 \mathrm{~cm} / \mathrm{yr}(17 \mathrm{in} . / \mathrm{yr}$ ) suggested that this value was too high because heads were calculated that were greater than J-Field's highest topographic elevation. While holding recharge constant at $30 \mathrm{~cm} / \mathrm{yr}(12 \mathrm{in} . / \mathrm{yr})$, the confining unit's conductivity was decreased from $1.8 \times 10^{-5}$ to $1.8 \times 10^{-7} \mathrm{~cm} / \mathrm{s}(0.05$ to $0.0005 \mathrm{ft} / \mathrm{d})$, which corresponds to a $\mathrm{K}_{\mathrm{V}}$ change from $1.8 \times 10^{-6}$ to $1.8 \times 10^{-8} \mathrm{~cm} / \mathrm{s}(0.005$ to $0.00005 \mathrm{ft} / \mathrm{d})$. During the calibration, minimizing the RMSE values at all the targets in both aquifers was not considered to be the main objective. Rather, heavy weighting was initially given to achieving confined aquifer heads approximately equal to those measured in the TBP area (Wells JF61 and JF41). A hydraulic conductivity for the confining unit of $5.3 \times 10^{-7} \mathrm{~cm} / \mathrm{s}(0.0015 \mathrm{ft} / \mathrm{d})$ horizontal, which corresponds to $5.3 \times 10^{-8} \mathrm{~cm} / \mathrm{s}(0.00015 \mathrm{ft} / \mathrm{d})$ vertical, was determined to be the calibrated value.

With this fixed confining unit conductivity value, recharge was varied from 19 to $38 \mathrm{~cm} / \mathrm{yr}$ (7.5 to 15 in./yr). Decreasing recharge through this range produced decreased RMSE values. Again, minimizing calibration statistics at all wells was considered less important than matching target heads for the TBP area (Wells JF63 and JF43). A recharge value of $27 \mathrm{~cm} / \mathrm{yr}$ (10.5 in./yr) produced an adequate match for the TBP area targets and reasonably close heads at the other calibration locations.

Figures 10,11 , and 12 present the contours of the calibrated head for the surficial aquifer throughout J-Field, the surficial aquifer near the TBP area, and the confined aquifer throughout J-Field, respectively. 


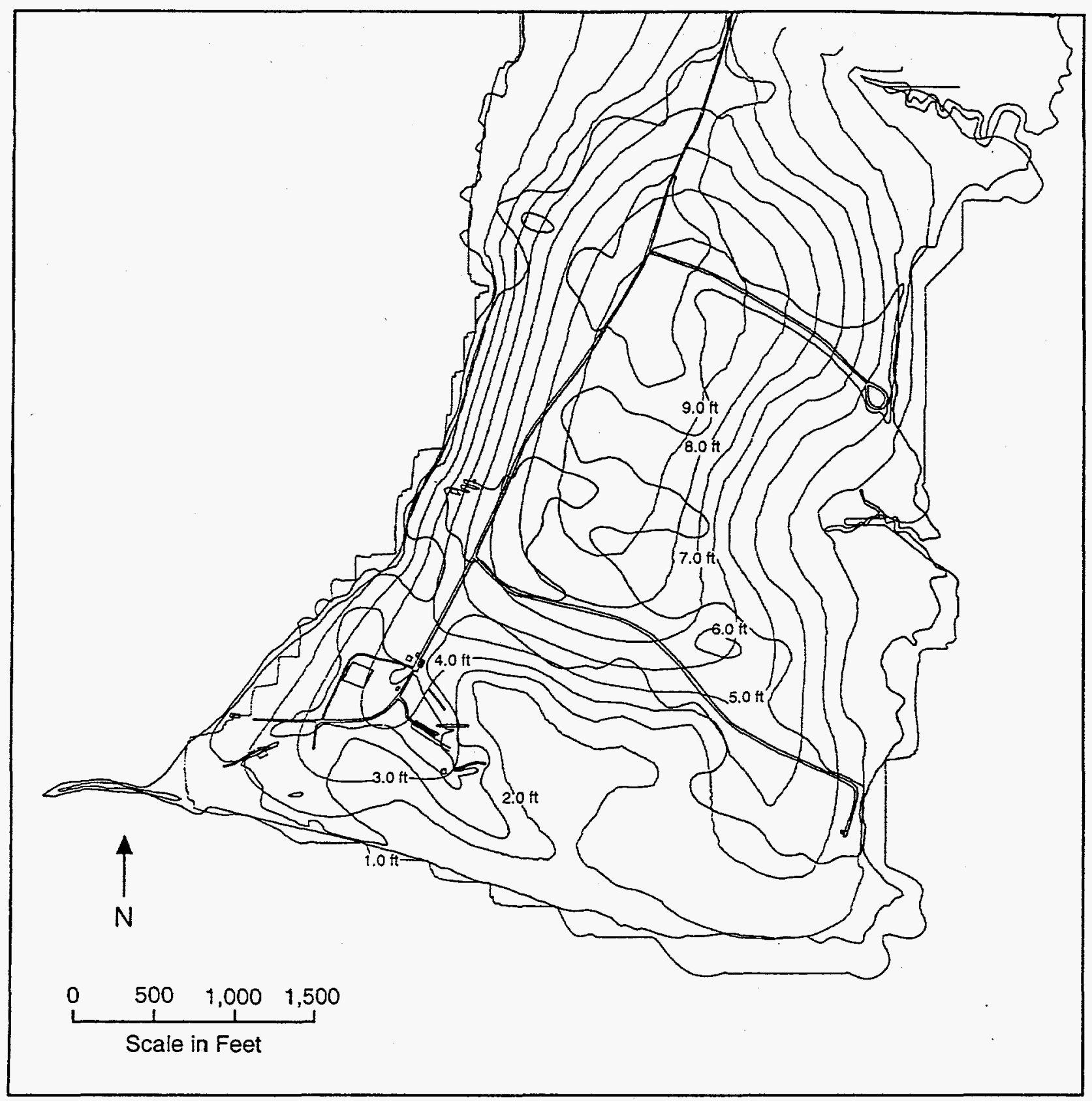

FIGURE 10 Simulated Heads in Surficial Aquifer (contour interval = $1 \mathrm{ft}$ )

Another factor useful in calibrating the model was a comparison of calculated heads with the topographic elevations. The model's design produced the highest heads along the center of the J-Field peninsula; the heads coincided with the highest topography. Some hydraulic conductivity and recharge values tested in calibration runs could be ruled out on the basis of simulated heads being greater than the topographic surface. For the calibrated values of hydraulic conductivity of the confining unit $\left(5.3 \times 10^{-7} \mathrm{~cm} / \mathrm{s}\right.$ or $\left.0.0015 \mathrm{ft} / \mathrm{d}\right)$ and recharge $(27 \mathrm{~cm} / \mathrm{yr}$ or $10.5 \mathrm{in} . / \mathrm{yr})$, the highest surficial aquifer head was $3.04 \mathrm{~m}(9.98 \mathrm{ft})$, which is acceptable. 


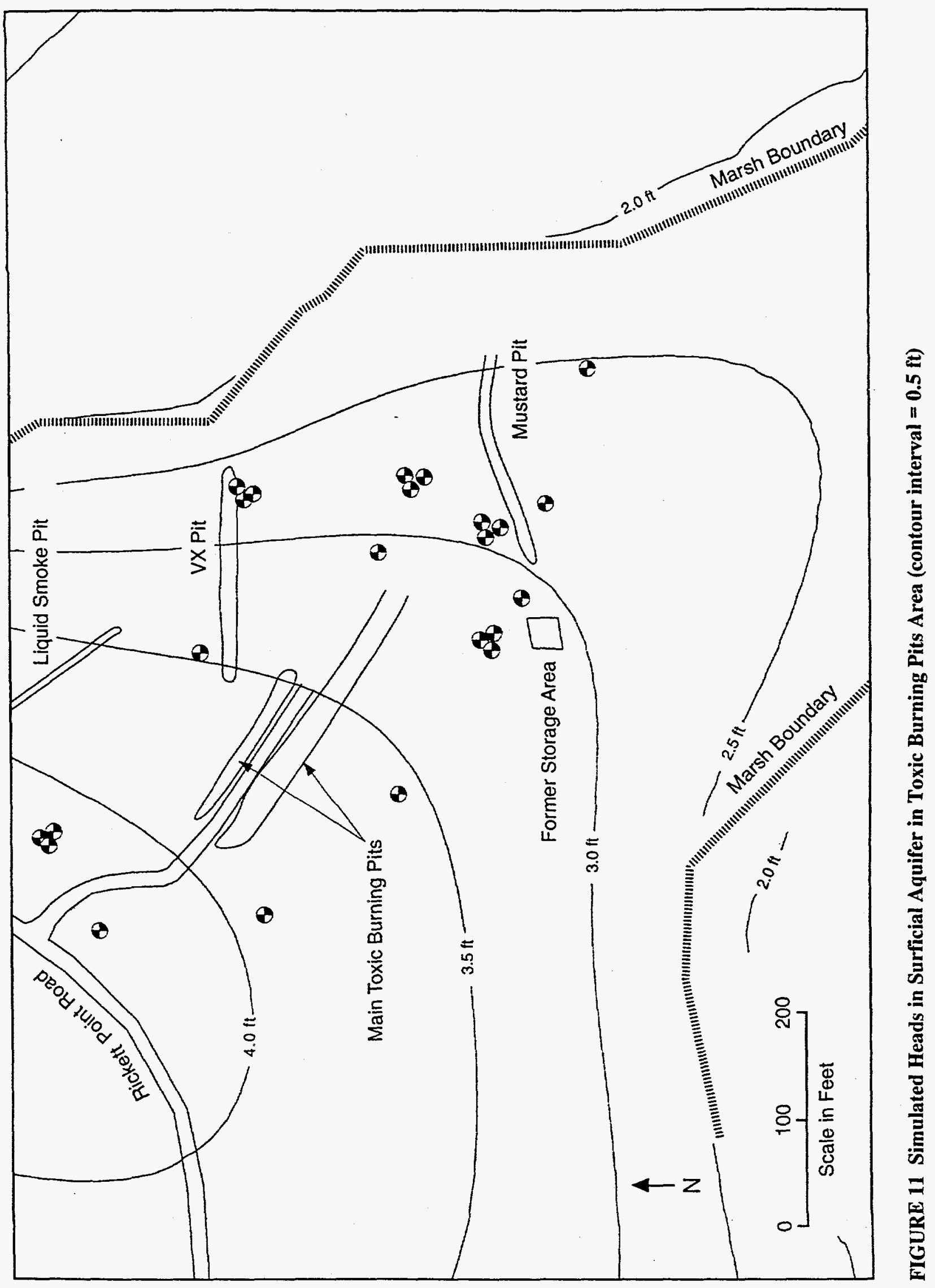




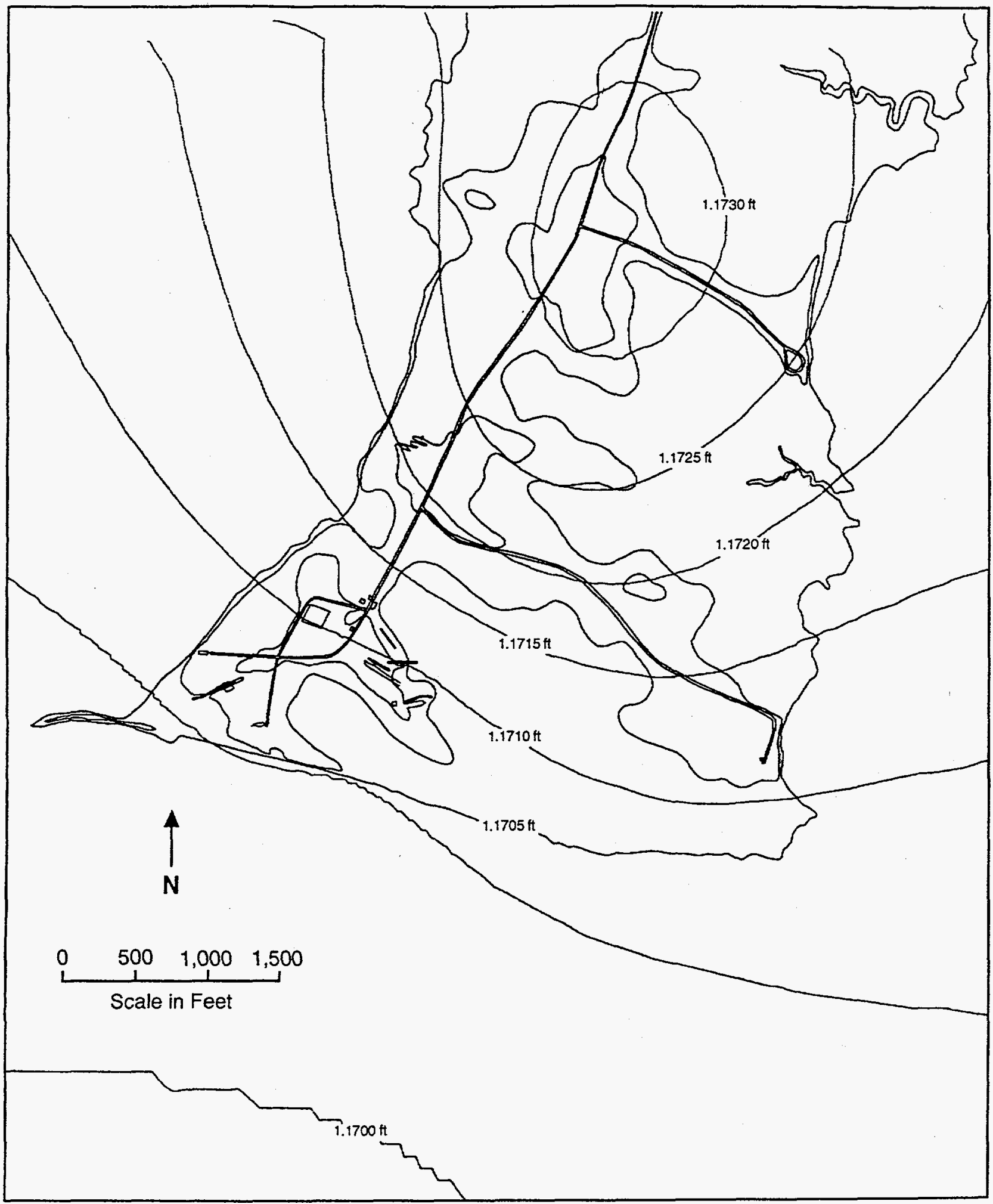

FIGURE 12 Simulated Heads in Confined Aquifer (contour interval $=0.0005 \mathrm{ft}$ ) 


\subsection{SENSITIVITY ANALYSIS}

The parameter values determined in a model calibration do not represent a unique solution. For this reason, a sensitivity analysis is a necessary part of a modeling study, in order to evaluate the effect that uncertainties in the model have on model output.

In this study, the steady-state simulated potentiometric surfaces of the surficial and confined aquifers were tested for their sensitivities to changes in five model parameters. The horizontal hydraulic conductivity of the surficial and confined aquifers, the vertical hydraulic conductivity of the confining unit, and the drain conductance were each analyzed by adjusting the calibrated value four ways: increased by a factor of two, increased one order of magnitude, decreased by a factor of two, and decreased one order of magnitude. The recharge was also tested by changing the calibrated value four ways: increased by $10 \%$, increased by a factor of two, decreased by $10 \%$, decreased by a factor of two. During each sensitivity test, all values except the parameter of interest were equal to the calibrated model values.

Changing the vertical conductivity of the confining unit resulted in a change in the vertical conductance between cells in all three model layers. These calculations were performed by ModelCad.

The sensitivity of the model was measured by comparing output from each run to the steady-state calibrated head value at each of the seven calibration locations. Statistics of each sensitivity run are included in Appendix $C$, and the results are summarized in Table 2. The surficial aquifer was found to be very sensitive to changes in the $\mathrm{K}_{\mathrm{H}}$ of the surficial aquifer and recharge, somewhat sensitive to changes in drain conductance, and insensitive to changes in $\mathrm{K}_{\mathrm{V}}$ of the confining unit and $\mathrm{K}_{\mathrm{H}}$ of the confined aquifer. The confined aquifer was insensitive to changes in all five parameters tested.

The model's sensitivity numerical factors were also tested. The iteration seed used in Modflow's strongly implicit procedure solution affected the output of simulations because of instability from the high hydraulic conductivity contrasts of the layers. This problem was avoided by specifying a seed equal to eight times the average seed. A convergence criteria on the order of $3 \times 10^{-6} \mathrm{~m}\left(1 \times 10^{-5} \mathrm{ft}\right)$ was determined to produce accurate heads for the confined aquifer. In all model runs, the volumetric budget error determined by Modflow was acceptable $(<1 \%)$.

The sensitivity of the model to the boundary conditions of the confined aquifer was not tested. The boundaries were chosen because they are quite far from the area of interest. Also, the present model has confined aquifer boundaries similar to those of Hughes (1995), who found his model to be insensitive when the no-flow boundaries of the confined aquifer were changed to constant-head boundaries. 
TABLE 2 Sensitivity of Flow Model to Aquifer Parameters

\begin{tabular}{|c|c|c|c|c|}
\hline $\begin{array}{l}\text { Parameter } \\
\text { of Interest }\end{array}$ & $\begin{array}{l}\text { Calibrated } \\
\text { Value }\end{array}$ & $\begin{array}{l}\text { Values } \\
\text { Tested }\end{array}$ & $\begin{array}{l}\text { Effect on } \\
\text { Surficial } \\
\text { Aquifer }\end{array}$ & $\begin{array}{l}\text { Effect on } \\
\text { Confined } \\
\text { Aquifer }\end{array}$ \\
\hline $\begin{array}{l}\mathrm{K}_{\mathrm{H}} \text { of } \\
\text { Surficial } \\
\text { Aquifer }\end{array}$ & $\begin{array}{l}1.2 \times 10^{-3} \mathrm{~cm} / \mathrm{s} \\
(5.3 \mathrm{ft} / \mathrm{d})\end{array}$ & $\begin{array}{l}\text { Increased by factors } \\
\text { of } 2 \text { and } 10 \text {, } \\
\text { decreased by } \\
\text { factors of } 2 \text { and } 10\end{array}$ & $\begin{array}{l}\text { Sensitive to } \\
\text { increases and } \\
\text { very sensitive to } \\
\text { decreases }\end{array}$ & $\begin{array}{l}\text { Slight changes } \\
\text { in heads }\end{array}$ \\
\hline $\begin{array}{l}\mathrm{K}_{\mathrm{V}} \text { of } \\
\text { Confining } \\
\text { Unit }\end{array}$ & $\begin{array}{l}5.3 \times 10^{-8} \mathrm{~cm} / \mathrm{s} \\
(0.00015 \mathrm{ft} / \mathrm{d})\end{array}$ & $\begin{array}{l}\text { Increased by factors } \\
\text { of } 2 \text { and } 10 \text {, } \\
\text { decreased by } \\
\text { factors of } 2 \text { and } 10\end{array}$ & $\begin{array}{l}\text { Negligible } \\
\text { changes }\end{array}$ & $\begin{array}{l}\text { Slight changes } \\
\text { in heads }\end{array}$ \\
\hline $\begin{array}{l}\mathrm{K}_{\mathrm{H}} \text { of } \\
\text { Confined } \\
\text { Aquifer }\end{array}$ & $\begin{array}{l}1.3 \times 10^{-1} \mathrm{~m} / \mathrm{s} \\
(390 \mathrm{ft} / \mathrm{d})\end{array}$ & $\begin{array}{l}\text { Increased by factors } \\
\text { of } 2 \text { and } 10 \text {, } \\
\text { decreased by } \\
\text { factors of } 2 \text { and } 10\end{array}$ & $\begin{array}{l}\text { Negligible } \\
\text { changes }\end{array}$ & $\begin{array}{l}\text { Slight changes } \\
\text { in heads }\end{array}$ \\
\hline $\begin{array}{l}\text { Drain } \\
\text { Conductance }\end{array}$ & $\begin{array}{l}9.3 \mathrm{~m}^{2} / \mathrm{d} \\
\left(100 \mathrm{ft}^{2} / \mathrm{d}\right)\end{array}$ & $\begin{array}{l}\text { Increased by factors } \\
\text { of } 2 \text { and } 10 \text {, } \\
\text { decreased by } \\
\text { factors of } 2 \text { and } 10\end{array}$ & $\begin{array}{l}\text { Slight effect by } \\
\text { two TBP area } \\
\text { measuring } \\
\text { points, minimal } \\
\text { elsewhere }\end{array}$ & $\begin{array}{l}\text { Slight changes } \\
\text { in heads }\end{array}$ \\
\hline Recharge & $\begin{array}{l}27 \mathrm{~cm} / \mathrm{yr} \\
(10.5 \mathrm{in} . / \mathrm{yr})\end{array}$ & $\begin{array}{l}\text { Increased by } 10 \% \\
\text { and factor of } 2 \text {, } \\
\text { decreased by } 10 \% \\
\text { and factor of } 2\end{array}$ & $\begin{array}{l}\text { Sensitive even } \\
\text { to } 10 \% \text { changes } \\
\text { (heads change } \\
\text { up to } 0.15 \mathrm{~m} \text { or } \\
0.5 \mathrm{ft} \text { ) }\end{array}$ & $\begin{array}{l}\text { Slight changes } \\
\text { in heads }\end{array}$ \\
\hline
\end{tabular}




\section{OPTIMIZATION OF PUMPING STRESSES}

\subsection{APPROACH}

Optimization techniques were selected to design a remedial action alternative for contaminated water in the surficial aquifer at the TBP area. To determine the number of wells needed, their locations, and their individual pump rates, linear programming was chosen to evaluate the effect of numerous possible well locations and to indicate optimal pumping arrangements for two scenarios. In both cases, the objective was to extract the minimal amount of water possible while honoring the constraints. Constraints included a user-specified containment boundary and a maximum pump rate for individual wells.

\subsection{MODEL SELECTION}

The optimization of stresses imposed by the groundwater extraction system was performed using ModMan (GeoTrans, Inc. 1992). ModMan serves as the communication link between calibrated Modflow input and output files and a linear programming package, LINDO (Schrage 1991). ModMan requires input on the objective and constraints of the optimization problem. These constraints may relate to hydrogeologic aspects of the situation (e.g., head or drawdown values or head differences) and pumping system design (e.g., number of wells and maximum pump rates of each). ModMan addresses the fundamental issues of (1) optimal locations of pumping wells and (2) optimal pump rate of each well.

\subsection{OPTIMIZATION OF EXTRACTION WELL PLACEMENT AND PUMP RATES}

With the calibrated flow model used as input to the optimization routine, two scenarios were investigated: containment and containment with cap. These scenarios represent preliminary remedial action alternatives under consideration for the TBP area.

A decision was made to restrict potential well locations to known or suspected source areas. In this manner, containment would be achieved with an emphasis on extraction of the most contaminated groundwater. Potential wells were placed at 45 model cells located at the two main pits and three other source areas (a former storage area, the VX pit, and the mustard pit) (Figure 13). Because the liquid smoke pit was determined not to pose a threat to groundwater, it was excluded from optimization modeling.

To provide containment, the head difference constraint was chosen and applied to a userspecified boundary approximately $30 \mathrm{~m}(100 \mathrm{ft})$ from the marsh boundary (Figure 13). With this 


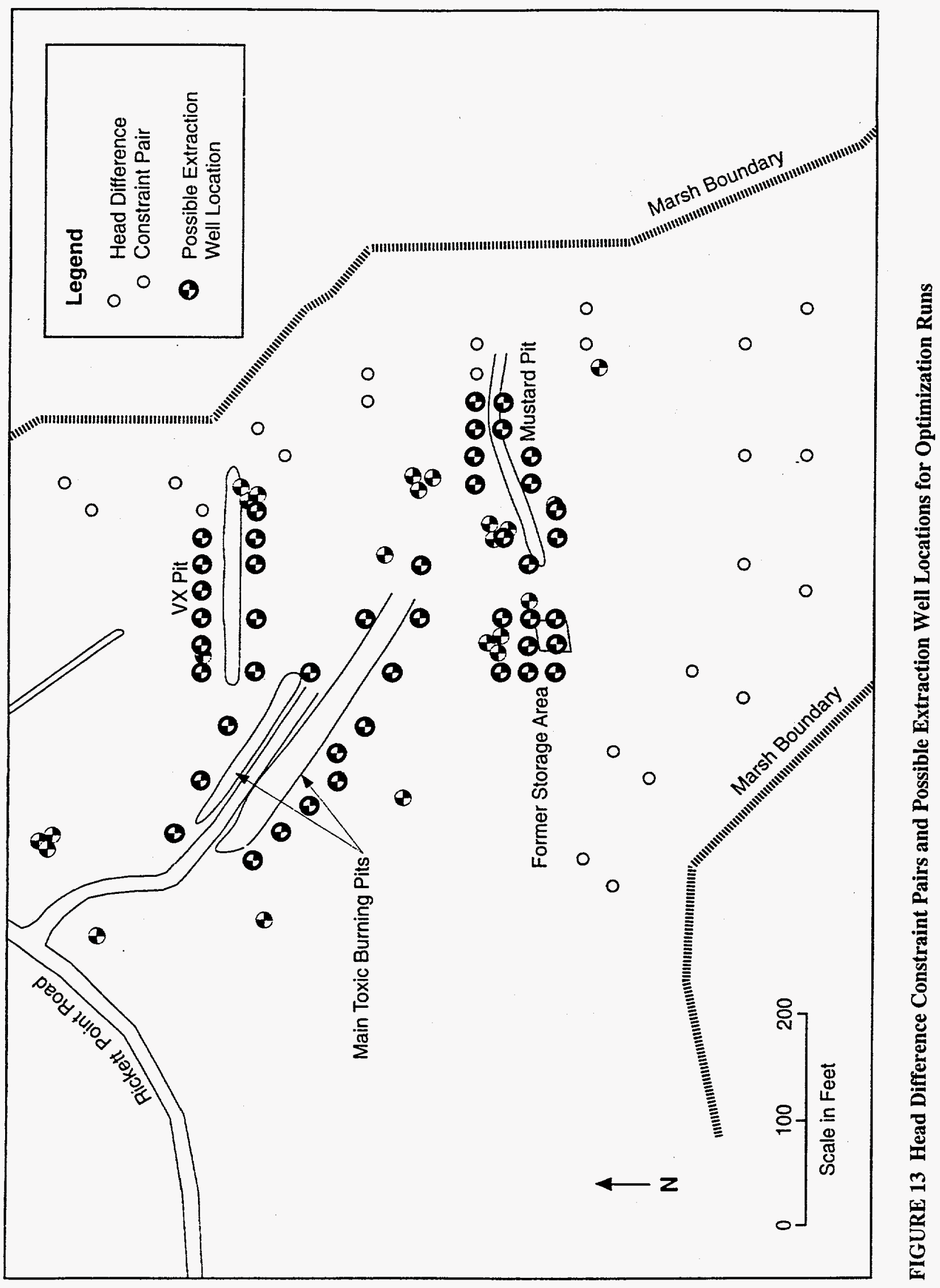


approach, ModMan was instructed to determine well pumping rates such that the head at the outer constraint node is equal to or greater than the head at the inner constraint node. Because the optimization code was striving to extract groundwater from the system at the lowest possible rate, the model tried to achieve equality between each pair of head difference nodes. In this manner, a groundwater divide would ideally be created along the constraint boundary. Otherwise, the routine would allow an inward gradient, which would cause some water from the marsh to be pumped, but would achieve the goal of preventing any groundwater discharge to the marsh.

The pump test of Well 183 (Quinn 1995) provided $0.063 \mathrm{~L} / \mathrm{s}(1 \mathrm{gal} / \mathrm{min})$ as the maximum yield of an individual well. This rate was from the pump testing of one over-designed well. Although lower or higher sustainable pump rates may be possible at other TBP area locations, this pump rate was assumed to be a best estimate of the maximum possible value.

\subsubsection{Containment}

In the first scenario, ModMan was initially instructed to choose a maximum of 20 wells. The code selected eight wells pumping a combined rate of $33.87 \mathrm{~m}^{3} / \mathrm{d}\left(1,196 \mathrm{ft}^{3} / \mathrm{d}\right)$. A second optimization run was performed with the maximum number of wells set to seven. Seven wells were

selected with a combined rate of $34.04 \mathrm{~m}^{3} / \mathrm{d}\left(1,202 \mathrm{ft}^{3} / \mathrm{d}\right)$. Figure 14 shows the resulting steady-state heads from this run. Another optimization run was performed with a maximum of six possible wells. No feasible solution could be determined by LINDO.

\subsubsection{Containment with Cap}

In this scenario, no infiltration was allowed in an area assumed to be covered with a cap (Figure 15). In this zone, model recharge was set to zero. Runoff of precipitation was assumed to be off the cap and into the marsh, and its effect on groundwater in the TBP area was assumed to be minimal. In the initial run, a maximum of 20 wells were allowed; ModMan chose six wells, with a combined pump rate of $25.5 \mathrm{~m}^{3} / \mathrm{d}\left(901 \mathrm{ft}^{3} / \mathrm{d}\right)$. The resulting steady-state heads are shown in Figure 15. Two of the wells are inside the cap boundary, which would be allowable in the cap design. A subsequent run was performed with a limit of five possible wells, but no feasible solution was found.

\subsubsection{Sensitivity of Optimized Solution to Aquifer Parameters}

Because of uncertainty in the values of aquifer parameters, the sensitivity of the optimization results was evaluated. The sensitivity was assumed to be of most concern for the two 


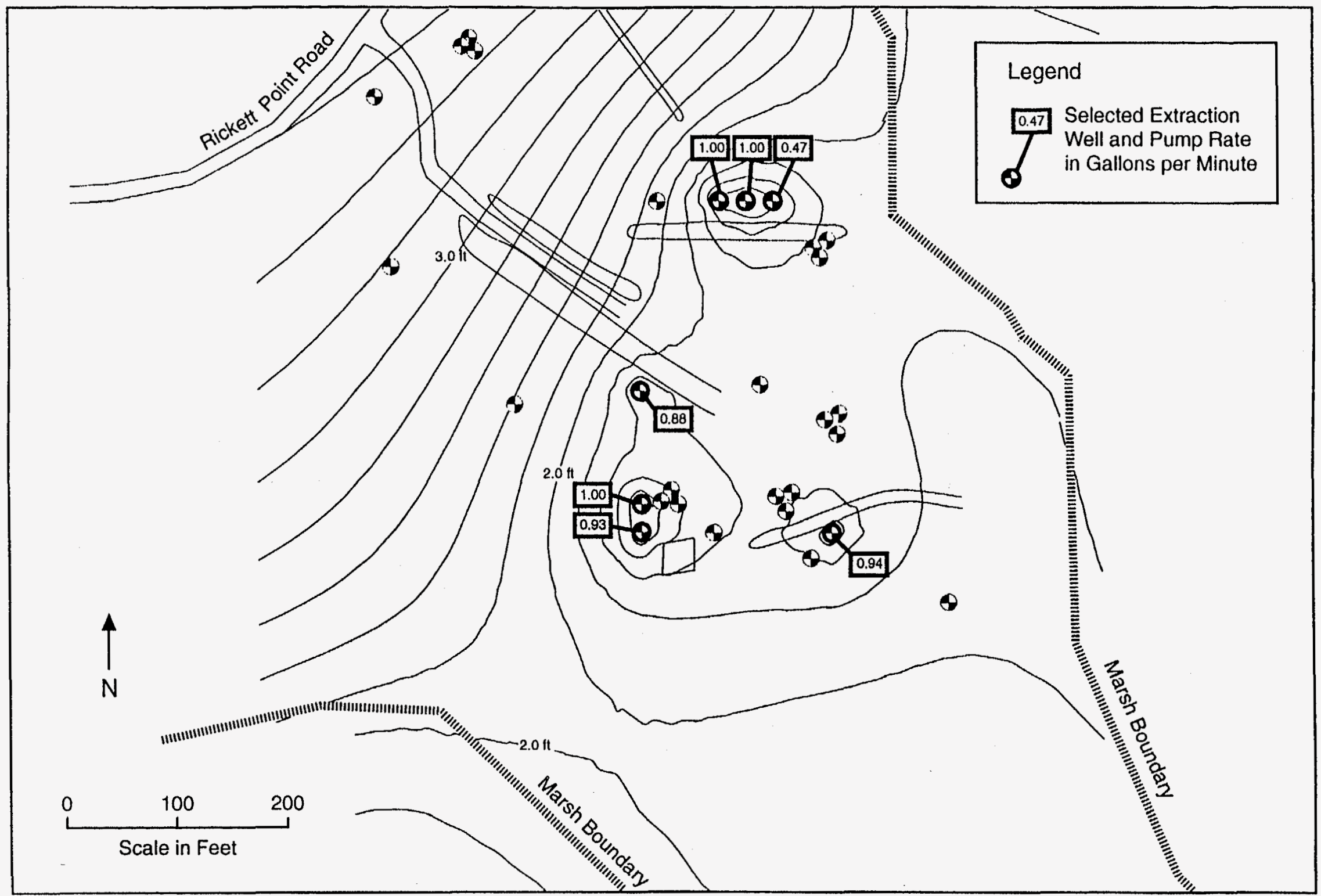

$\ddot{w}$

FIGURE 14 Results for Containment Case with Optimum Seven Wells (contour interval $=0.2 \mathrm{ft}$ ) 


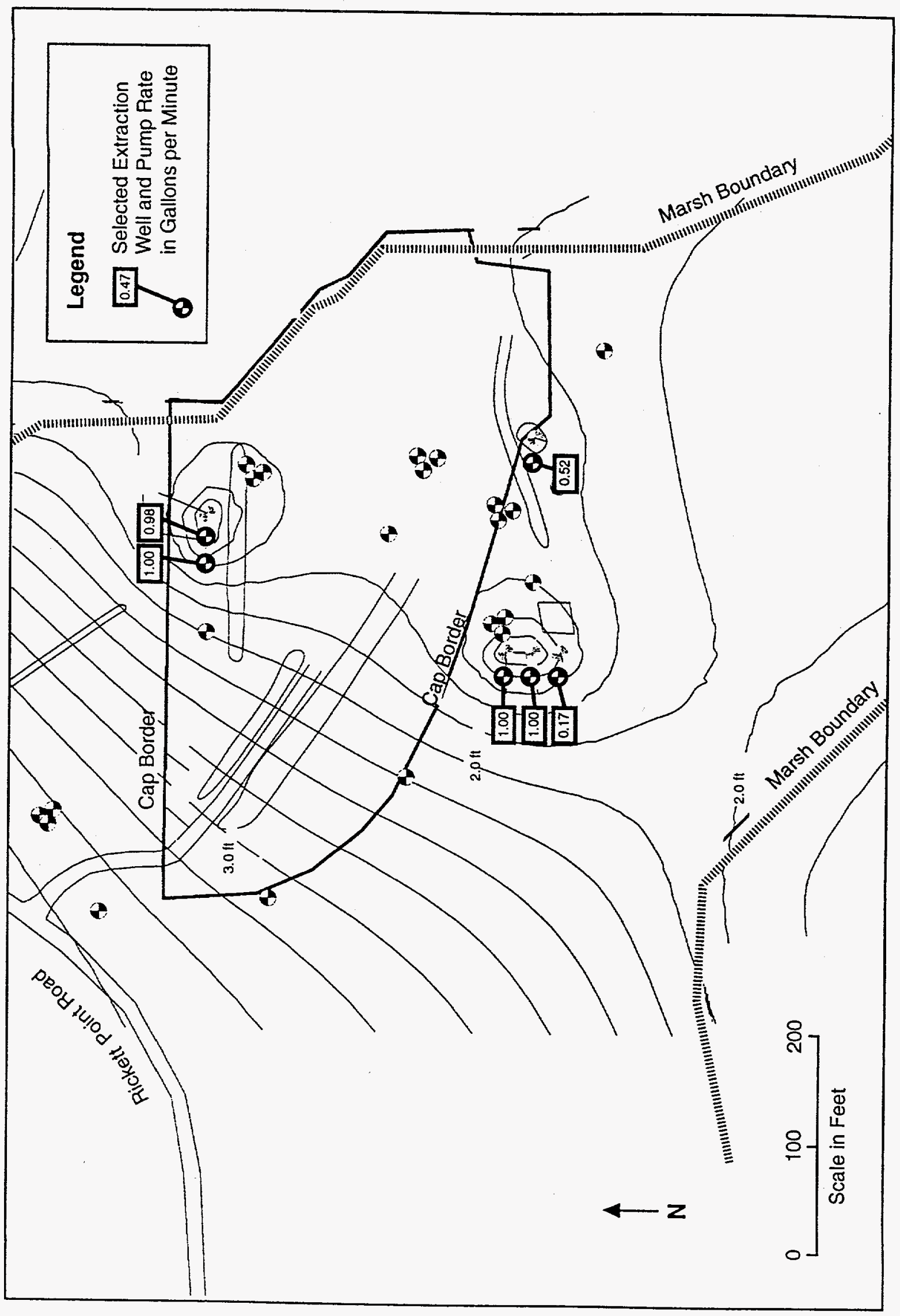

告 
most sensitive parameters in the flow model sensitivity analysis: recharge and the hydraulic conductivity of the surficial aquifer.

The sensitivity analysis focused on the containment case with the maximum number of possible wells set to 20 . Comparisons were made between the results obtained by using calibrated and altered values. As shown in Table 3, the results indicate that as recharge was varied within $10 \%$ of the calibrated value, the optimization solution was fairly insensitive to the change since the flow rates change somewhat but the number of wells required remains consistent. As the recharge was changed by a factor of two, both the number of wells and the total pump rate changed by approximately the same amount.

In the case of varying the hydraulic conductivity of the surficial aquifer, the solution was insensitive to decreases of at least one order of magnitude. The total pump rate increased only slightly, and eight wells were required for each run. The results were similar for a factor of two increase, but when the conductivity was increased one order of magnitude, the solution changed dramatically. The sudden increase in total pump rate and number of required wells occurred because even when in the absence of pumping, the high transmissivity of the unconfined aquifer causes the steady-state heads in the TBP area to fall below the drain elevation. Consequently, rather than mimicking the peninsular shape of the TBP area, the potentiometric contours were independent of drain locations, and heads were simply based on distance from the bay. Modeled groundwater flow throughout the TBP area, therefore, was to the southwest, and the head difference constraint was met along the eastern portion of the TBP area without the use of any pumping wells. The 13 wells selected by the optimization code were all in the former storage area and the western portion of the Mustard Pit (Figure 13) in order to achieve containment along the southern constraint boundary. The high pump rate and number of required wells were necessary because the wells have decreased radii of influence in the more permeable aquifer. This high sensitivity to increased conductivity is important because the bulk conductivity of the surficial aquifer may vary spatially by more than one order of magnitude.

\subsubsection{Discussion of Optimization Results}

A goal of the optimization modeling was to provide containment of groundwater within the TBP area to protect the ecology of the marsh from the discharge of contaminated groundwater. Figures 14 and 15 indicate that this goal was attained, because each case shows a flow divide along most of the constraint boundary. In both cases, an inward gradient was present along only a small portion of the marsh boundary. These results suggest that a second objective, namely minimal effect on the marsh hydrology, was also successfully achieved. Although the pumping scheme draws some water from the marsh, this amount is minimal compared to the groundwater input across the rest of the marsh's border (Figure 10). 
TABLE 3 Sensitivity of Optimization Results to Aquifer Parameters

\begin{tabular}{|c|c|c|c|c|c|}
\hline \multirow[b]{2}{*}{ Input } & \multicolumn{5}{|c|}{ Sensitivity to Changes in Recharge (R) } \\
\hline & & & & & \\
\hline Recharge value tested & $0.5 \mathrm{R}$ & $0.9 \mathrm{R}$ & Calibrated R & $1.1 \mathrm{R}$ & $2 \mathrm{R}$ \\
\hline Recharge rate (in./yr) & 5.25 & 9.45 & 10.5 & 11.55 & 21 \\
\hline \multicolumn{6}{|l|}{ Results } \\
\hline Total pump rate $\left(\mathrm{ft}^{3} / \mathrm{yr}\right)$ & 538 & 1,063 & 1,196 & 1,329 & 2,584 \\
\hline \multirow[t]{2}{*}{ Number of wells required } & 5 & 8 & 8 & 8 & 15 \\
\hline & \multicolumn{5}{|c|}{ Sensitivity to Changes in Surficial Aquifer Hydraulic Conductivity (K) } \\
\hline \multicolumn{6}{|l|}{ Input } \\
\hline $\begin{array}{l}\text { Hydraulic conductivity } \\
\text { value tested }\end{array}$ & $0.1 \mathrm{~K}$ & $0.5 \mathrm{~K}$ & Calibrated $\mathrm{K}$ & $2 \mathrm{~K}$ & $10 \mathrm{~K}$ \\
\hline $\begin{array}{l}\text { Hydraulic conductivity } \\
\text { (ft/d) }\end{array}$ & 0.53 & 2.65 & 5.3 & 10.6 & 53 \\
\hline \multicolumn{6}{|l|}{ Results } \\
\hline Total pump rate $\left(\mathrm{ft}^{3} / \mathrm{yr}\right)$ & 1,387 & 1,253 & 1,196 & 1,099 & 2,315 \\
\hline Number of wells required & 8 & 8 & 8 & 8 & 13 \\
\hline
\end{tabular}

A comparison of the available well locations (Figure 13) and the results for the two cases (Figures 14 and 15) clearly show that the optimization routine favors wells located close to the constraint boundary. No wells along the main pits were chosen. The closer a well is to the constraint boundary, the more efficient it is at satisfying the model objective of minimal pumping to halt discharge to the marsh.

In an additional model run, wells were located throughout the entire TBP area, and only those wells closest to the constraint boundary were chosen. The pumping scheme created a groundwater divide along the entire boundary with greater efficiency than in the case of wells located only at sources, as a lesser total pump rate was required.

In general, incrementally decreasing the maximum number of allowable wells should result in increased total pump rates from the system. In the containment scenario, when the maximum number of wells was limited to seven, the total pumpage was only slightly greater than in the case of eight optimum wells. This result can be attributed to the sensitivity of the solution to the initial placement of potential wells.

The sensitivity analysis indicated that the optimization solution has a low sensitivity to reasonable changes in recharge and to decreases in hydraulic conductivity. The solution, however, 
is highly sensitive to increases in conductivity that result in natural-scenario heads dropping below the marsh level. Pump tests of any future extraction wells would provide data to refine the surficial aquifer's bulk hydraulic conductivity distribution in the TBP area and increase the certainty of the optimization results. 


\section{SUMMARY AND RECOMMENDATIONS}

This study indicated the optimal placement and minimal pumping rates necessary to provide containment of groundwater at the TBP area while limiting possible well locations to known source areas. Optimization was achieved using linear programming combined with specified constraints, including the maximum yield of wells and the placement of a constraint boundary.

The results shown for the cases of containment and containment with cap provide the optimal design for a groundwater extraction system at the TBP area. An important factor incorporated by the optimization modeling was the low yield of the possible wells. Because pumptested Well 183 was designed to be an extraction well yet it yielded water slowly, simulated wells were purposefully limited in their ability to pump. The result was a larger number of required wells than would be necessary in a case of unrestricted yield for modeled wells.

The optimization modeling was based on an application of linear programming to a system that includes nonlinear elements (e.g., unconfined flow and flow to drains). Any error associated with this application was assumed to be negligible, especially in comparison with errors resulting from the variability and uncertainty of model input parameters. While a great deal of data have been collected at J-Field, data gaps are present. In the flow model, the data gaps include aquifer parameters identified as sensitive, namely the hydraulic conductivity of the surficial aquifer and recharge. In the optimization modeling, results were found to be fairly insensitive to reasonable changes in recharge and to decreases in hydraulic conductivity. However, increases in conductivity had a significant effect on optimization model output if the resulting natural-scenario heads fell low enough to change flow directions in the containment area. While recharge is typically difficult to measure, additional estimates of hydraulic conductivity should be obtained through pump tests at any fully screened pumping wells installed in a remediation effort. This information would provide greater confidence in the value and/or the degree of variability of the bulk horizontal hydraulic conductivity of the aquifer. Measured values that vary significantly from that measured at Well 183 may warrant re-evaluation of the optimization design. In addition, if well yield values obtained during the pump tests differ significantly from the $0.063 \mathrm{~L} / \mathrm{s}(1 \mathrm{gal} / \mathrm{min})$ measured at Well 183 , the optimization design may need modification.

Well 183 was installed to perform aquifer testing and to serve as a possible future extraction well. Although none of the selected wells in Figures 14 and 15 coincide with the Well 183 location, the well is within about $15 \mathrm{~m}(50 \mathrm{ft})$ of candidate well locations and could be a reasonable substitution for one of the optimization wells because of its proximity and the issues of parameter uncertainty and model resolution.

The water table at J-Field changes according to seasonal changes and precipitation events. Future modeling efforts could be directed toward exploring transient effects of seasonal changes in recharge on the output of the optimization model. Other seasonal aspects could be included in this 
analysis, such as the change in areal extent of the marshes. This fluctuation has not been evaluated because of limited aerial photographic coverage of the site over time, and it represents another data gap.

The optimization code enables the user to specify a maximum number of wells to allow per simulation. In this study, the number of pumping wells was inversely proportional to the overall pump rate of the system. By sequentially decreasing the number of wells allowed, the user can explore the trade-off between the number of pumping wells versus the total rate of groundwater extraction. This type of analysis is useful in determining the relationship between initial costs (well installations) and on-going costs (rate of water requiring treatment). The minimum number of wells providing a feasible solution is also determined. In this study, the containment case indicated a negligible difference in total pump rate between the simulations using eight and seven pumping wells. A significant decrease in initial well construction costs could, therefore, be realized with essentially no change in the on-going treatment costs. In the case of containment with cap, however, only one optimum solution was possible. 


\section{REFERENCES}

Anderson, M.P., and W.W. Woessner, 1992, Applied Groundwater Modeling - Simulation of Flow and Advective Transport, Academic Press, Inc., San Diego, Calif.

Argonne National Laboratory, 1995, Remedial Investigation Sampling and Analysis Plan for J-Field, Aberdeen Proving Ground, Maryland, Volume 1: Field Sampling Plan, prepared by Environmental Assessment Division for Aberdeen Proving Ground, Directorate of Safety, Health, and Environment, Argonne National Laboratory, Ill., March.

Bradbury, K.R., and M.A. Muldoon, 1990, "Hydraulic Conductivity Determinations in Unlithified Glacial and Fluvial Materials," in Ground Water and Vadose Zone Monitoring, D.M. Nielsen and A.I. Johnson (editors), ASTM STP 1053, American Society for Testing and Materials, Philadelphia, Pa., pp. 138-151.

ConSolve, Inc., 1993, SitePlanner, Version 1.2, Lexington, Mass.

Cooper, H.H., et al., 1967, "Response of a Finite-Diameter Well to an Instantaneous Charge of Water," Water Resources Research 3(1):263-269.

Drummond, D.D., and J.D. Blomquist, 1993, Hydrogeology, Water-Supply Potential, and Water Quality of the Coastal Plain Aquifers of Harford County, Maryland, Maryland Geological Survey Report of Investigations No. 58, Baltimore, Md.

Englund, E., and A. Sparks, 1991, Geo-EAS 1.2.1 User's Guide, EPA 600/8-91/008, U.S. Environmental Protection Agency, Washington, D.C.

ERM Program Management Company, 1995, Results from the Pumping Test Performed at Aberdeen Proving Ground, Maryland, Exton, Pa.

Freeze, R.A., and J.A. Cherry, 1979, Groundwater, Prentice-Hall, Inc., Englewood Cliffs, N.J.

GeoTrans, Inc., 1992, MODMAN: An Optimization Module for MODFLOW, Version 2.1, Sterling, Va., July.

Geraghty and Miller, Inc., 1993, ModelCad386, Version 2.13, Reston, Va.

Hughes, W.B., 1991, "Application of Marine Seismic Profiling to a Ground Water Contamination Study," Aberdeen Proving Ground, Maryland, Ground Water Monitoring Review 11(1):97-102. 
Hughes, W.B., 1992, Use of Marine-Seismic Profiling to Study Ground-Water Contamination at Aberdeen Proving Ground, Maryland, in Proceedings of the Symposium on the Application of Geophysics to Engineering and Environmental Problems, R.S. Bell (editor), p. 163-172.

Hughes, W.B., 1993a, personal communication from W.B. Hughes (U.S. Geological Survey, Towson, Md.), to J.J. Quinn (Argonne National Laboratory, Environmental Assessment Division, Argonne, Ill.), Nov. 9.

Hughes, W.B., 1993b, written communication from Hughes (U.S. Geological Survey, Towson, Md.), to J.J. Quinn (Argonne National Laboratory, Environmental Assessment Division, Argonne, III.), Nov. 10.

Hughes, W.B., 1993c, Hydrogeology and Soil Gas at J-Field, Aberdeen Proving Ground, Maryland, Water Resources Investigations Report 92-4087, U.S. Geological Survey, Towson, Md.

Hughes, W.B., 1995, Ground-Water Flow and the Possible Effects of Remedial Actions at J-Field, Aberdeen Proving Ground, Maryland, Water Resources Investigations Report 95-4075, U.S. Geological Survey, Towson, Md.

Hvorslev, M.J., 1951, Time Lag and Soil Permeability in Groundwater Observations, Bulletin No. 36, U.S. Army Corps of Engineers Waterways Experimental Station, Vicksburg, Miss.

Isaaks, E.C., and R.M. Srivastava, 1989, Applied Geostatistics, Oxford University Press, New York, N.Y.

James, R.W., and M.J. Smigaj, 1992, Water Resources Data, Maryland and Delaware, Water Year 1992, Volume 2: Ground-Water Data, Water-Data Report MD-DE-92-2, U.S. Geological Survey, Towson, Md.

Kerhin, R.T., et al., 1988, The Surficial Sediments of the Chesapeake Bay, Maryland: Physical Characteristics and Sediment Budget, Report of Investigations No. 48, Maryland Geological Survey, Baltimore, Md.

Lorah, M.M., and J.S. Clark, 1995, Contamination of Groundwater, Surface Water, and Soil, and Evaluation of Selected Pumpage Scenarios in the Canal Creek Area of Aberdeen Proving Ground, Maryland, Open-File Report 95-282, U.S. Geological Survey, Towson, Md.

McDonald, M.G., and A.W. Harbaugh, 1988, "A Modular Three-Dimensional Finite-Difference Ground-Water Flow Model," Techniques of Water Resources Investigations, Book 6, Chapter A1, U.S. Geological Survey, Reston, Va. 
National Oceanic and Atmospheric Administration, 1993, Chesapeake Bay Approaches to Baltimore Harbor, Map 12278, Washington, D.C.

Nemeth, G., et al., 1983, Environmental Survey of the Edgewood Area of Aberdeen Proving Ground, Maryland, U.S. Army Toxic and Hazardous Materials Agency, Report No. DRXTH-AS-FR-82185, Aberdeen Proving Ground, Md.

Nemeth, G., 1989, RCRA Facility Assessment, Edgewood Area, Aberdeen Proving Ground, Maryland, Assessment No. 39-26-0490-90, U.S. Army Environmental Hygiene Agency, Waste Disposal Engineering Division, prepared for Aberdeen Proving Ground Test and Evaluation Command, U.S. Army Material Command, Aberdeen Proving Ground, Md., Nov.

Nwankwor, G.I., et al., 1992, "Unsaturated and Saturated Flow in Response to Pumping of an Unconfined Aquifer: Field Evidence of Delayed Drainage," Ground Water 30(5): 690-700.

Oliveros, J.P., and D.A. Vroblesky, 1989, Hydrogeology of Canal Creek Area, Aberdeen Proving Ground, Maryland, Water-Resources Investigation Report 89-4021, U.S. Geological Survey, Towson, Md.

Otton, E.G., and R.J. Mandle, 1984, Hydrogeology of the Upper Chesapeake Bay Area, Maryland, with Emphasis on Aquifers in the Potomac Group, Report of Investigations No. 39, Maryland Geological Survey, Baltimore, Md.

Patton, T.L., 1994, Installation of Well 173 at J-Field, Aberdeen Proving Ground, Maryland: J-Field Remedial Investigation Technical Update, TU-2/ANL/APG/J-F/RI, Rev. 1, Argonne National Laboratory, Argonne, Ill.

Perkins, S.O., and H.B. Winant, 1927, Soil Survey of Harford County, Maryland, U.S. Department of Agriculture, Washington, D.C.

Princeton Aqua Science, 1984, Munitions Disposal Study, prepared for Directorate of Engineering and Housing, Environmental Management Office, Department of the Army, Aberdeen Proving Ground, Md., Nov.

Quinn, J.J., 1995, Pump Test of Well 183 at J-Field, Aberdeen Proving Ground, Maryland: J-Field Remedial Investigation Technical Update, TU-17/ANL/APG/J-F/RI, Argonne National Laboratory, Argonne, Ill.

Schrage, L, 1991, LINDO: An Optimization Modeling System, Release 5.0, The Scientific Press, South San Francisco, Calif. 
Smith, H., and E.D. Matthews, 1975, Soil Survey of Harford County Area, Maryland, U.S. Department of Agriculture and Soil Conservation Service, Washington, D.C, in cooperation with the Maryland Agricultural Experiment Station.

U.S. Geological Survey, 1989, Baltimore SE Color-Infrared Aerial Photograph 19-120, National Aerial Photography Program, April 20.

Vroblesky, D.A., et al., 1989, Ground-Water, Surface-Water, and Bottom-Sediment Contamination in the O-Field Area, Aberdeen Proving Ground, Maryland, and the Possible Effects of Selected Remedial Actions on Ground Water, Open-File Report 89-399, U.S. Geological Survey, Towson, Md.

Weston, Roy F., Inc., 1992, J-Field Topography and Existing Conditions Record Drawing, Drawing RFW/APG-006-001, July 30 .

Weston, Roy F., Inc., 1994, Final Report, Sampling and Analyses, Gunpowder Neck Site, Phase II, Aberdeen Proving Ground, Edgewood, Maryland, prepared for U.S. Environmental Protection Agency, Environmental Response Team, Washington, D.C., Feb.

Yuen, C.R., 1994, Identification of Potential Areas of Concern at J-Field, Aberdeen Proving Ground, Maryland: J-Field Remedial Investigation Technical Update, TU-13/ANL/APG/J-F/RI, Argonne National Laboratory, Argonne, Ill. 
APPENDIX A:

HYDROSTRATIGRAPHIC CONTACT DATA FOR GEOSTATISTICAL INTERPOLATION 
A-2 
TABLE A.1 Hydrostratigraphic Contact Data for Geostatistical Interpolation

\begin{tabular}{|c|c|c|c|c|c|c|c|c|c|}
\hline Well or Boring Name ${ }^{a}$ & $\begin{array}{c}\text { Easting } \\
(\mathrm{ft})\end{array}$ & $\begin{array}{l}\text { Northing } \\
\text { (ft) }\end{array}$ & $\begin{array}{c}\text { Land } \\
\text { Elevation } \\
\text { (ft MSL) }\end{array}$ & $\begin{array}{l}\text { Depth to } \\
\text { Top of } \\
\text { Confining } \\
\text { Unit (ft) }\end{array}$ & $\begin{array}{c}\text { Elevation of } \\
\text { Top of } \\
\text { Confining } \\
\text { Unit } \\
\text { (ft MSL) }\end{array}$ & $\begin{array}{l}\text { Depth to } \\
\text { Top of } \\
\text { Confined } \\
\text { Aquifer } \\
\text { (ft) }\end{array}$ & $\begin{array}{c}\text { Elevation of } \\
\text { Top of } \\
\text { Confined } \\
\text { Aquifer } \\
\text { (ft MSL) }\end{array}$ & $\begin{array}{l}\text { Depth to } \\
\text { Bottom of } \\
\text { Confined } \\
\text { Aquifer } \\
\text { (ft) }\end{array}$ & $\begin{array}{c}\text { Elevation of } \\
\text { Bottom of } \\
\text { Confined } \\
\text { Aquifer } \\
\text { (ft MSL) }\end{array}$ \\
\hline JF9 cluster & $1,000,660$ & 537,414 & 10.18 & 30 & -19.82 & $-^{b}$ & - & - & - \\
\hline JF11 cluster & $1,000,350$ & 537,561 & 6.51 & 30 & -23.49 & 67 & -60.49 & - & - \\
\hline JF10 cluster & $1,000,420$ & 537,627 & 5.36 & 29 & -23.64 & 67 & -61.64 & & - \\
\hline JF12 cluster & $1,000,490$ & 537,704 & 4.16 & 29 & -24.84 & 63.5 & -59.34 & - & - \\
\hline JF2 cluster & 999,241 & 535,919 & 2.99 & 29 & -26.01 & 66 & -63.01 & - & - \\
\hline EB4 and JF1 cluster & 999,473 & 535,903 & 7.42 & 29 & -21.58 & 78 & -70.58 & 120 & -112.58 \\
\hline EB3 and JF3 cluster & 999,767 & 536,435 & 7.67 & 33 & -25.33 & 80 & -72.33 & 116 & -108.33 \\
\hline JF4 cluster & $1,000,280$ & 536,209 & 10.22 & 39 & -28.78 & 74 & -63.78 & - & - \\
\hline JF6 cluster & $1,000,610$ & 536,027 & 4.29 & 29 & -24.71 & - & - & - & - \\
\hline JF5 cluster & $1,000,610$ & 535,865 & 5.02 & 36.5 & -31.48 & - & - & - & - \\
\hline JF7 cluster & $1,000,560$ & 535,796 & 7.26 & 39 & -31.74 & - & - & 一 & - \\
\hline EB2 and JF8 cluster & $1,000,450$ & 535,790 & 10.01 & 37 & -26.99 & 114 & -103.99 & 130 & -119.99 \\
\hline EB1 (approx.) & $1,000,370$ & 536,500 & 5 & 25 & -20 & 80 & -75 & 160 & -155 \\
\hline EB5 (approx.) & $1,000,700$ & 537,500 & 10 & 30 & -20 & 70 & -60 & 120 & -110 \\
\hline EB6 and JFl (Cret) & $1,003,000$ & 535,000 & 4.95 & 40 & -35.05 & 147 & -142.05 & 200 & -195.05 \\
\hline EB7 and JF2 (Cret) (approx.) & $1,001,800$ & 539,400 & 7 & 40 & -33 & 78 & -71 & 120 & -113 \\
\hline
\end{tabular}

a JF1 cluster $=$ one of the 12 USGS cluster well sites; EB1 = one of the 7 USGS deep exploratory borings; approx. = coordinates and land elevation at the well are approximate; Cret $=$ one of 2 USGS wells finished in the Cretaceous sediments.

b $-=$ data not available. 
A-4 
$B-1$

APPENDIX B:

MODEL CALIBRATION SUMMARIES 
B-2 
TABLE B.1 Calibration Statistics for J-Field Wells: Model Run 16

Model run attributes

Horizontal hydraulic conductivity of layer $1(\mathrm{ft} / \mathrm{d})=5.3$

Horizontal hydraulic conductivity of layer $2(\mathrm{ft} / \mathrm{d})=0.0015$

Horizontal hydraulic conductivity of layer $3(\mathrm{ft} / \mathrm{d})=390$

Recharge (in./yr) $=9$

\begin{tabular}{lllll} 
& Well & \multicolumn{1}{c}{$\begin{array}{c}\text { Nearby } \\
\text { Site Feature }\end{array}$} & $\begin{array}{c}\text { Water Year } \\
\text { Mean Head } \\
\text { (ft MSL) }\end{array}$ & $\begin{array}{c}\text { Model Run } \\
\text { Head } \\
\text { (ft MSL) }\end{array}$ \\
\hline \multirow{3}{*}{ Surficial aquifer } & & & & \\
& JF63 & Toxic burn pits & 2.77 & 2.55 \\
& JF43 & Toxic burn pits & 3.41 & 3.72 \\
& JF33 & Prototype building & 3.32 & 2.77 \\
& JF23 & Riot control pit & 1.47 & 1.78 \\
& JF13 & Riot control pit & 1.83 & 2.33 \\
& JF113 & White phosphorus pit & 1.80 & 2.08 \\
& JF93 & White phosphorus pit & 2.76 & 5.51
\end{tabular}

Mean error $(\mathrm{ft})=0.48$

Mean absolute error $(\mathrm{ft})=0.70$

Root mean squared error $(\mathrm{ft})=1.10$

$\begin{array}{lllll}\text { Confined aquifer } & \text { JF61 } & \text { Toxic burn pits } & 1.24 & 1.15 \\ & \text { JF41 } & \text { Toxic burn pits } & 1.11 & 1.15 \\ \text { JF31 } & \text { Prototype building } & 0.95 & 1.15 \\ \text { JF21 } & \text { Riot control pit } & 1.04 & 1.15 \\ \text { JF11 } & \text { Riot control pit } & 1.05 & 1.15 \\ \text { JF111 } & \text { White phosphorus pit } & 1.07 & 1.15 \\ \text { JF91 } & \text { White phosphorus pit } & 1.09 & 1.15\end{array}$

Mean error $(\mathrm{ft})=0.07$

Mean absolute error $(\mathrm{ft})=0.10$

Root mean squared error $(\mathrm{ft})=0.11$

Note: "1993 Water Year Mean Head" was determined by averaging data from continuous head recorders maintained by the USGS. The period of record is September 1992 through October 1993. 
TABLE B.2 Calibration Statistics for J-Field Wells: Model Run 17

\section{Model run attributes}

Horizontal hydraulic conductivity of layer $1(\mathrm{ft} / \mathrm{d})=5.3$

Horizontal hydraulic conductivity of layer $2(\mathrm{ft} / \mathrm{d})=0.0015$

Horizontal hydraulic conductivity of layer $3(\mathrm{ft} / \mathrm{d})=390$

Recharge (in./yr) $=10.5$

\begin{tabular}{|c|c|c|c|c|}
\hline & $\begin{array}{c}\text { Well } \\
\text { Name }\end{array}$ & $\begin{array}{c}\text { Nearby } \\
\text { Site Feature }\end{array}$ & $\begin{array}{c}1993 \\
\text { Water Year } \\
\text { Mean Head } \\
(\mathrm{ft} \text { MSL) }\end{array}$ & $\begin{array}{c}\text { Model Run } \\
\text { Head } \\
\text { (ft MSL) }\end{array}$ \\
\hline \multirow[t]{7}{*}{ Surficial aquifer } & JF63 & Toxic burn pits & 2.77 & 2.70 \\
\hline & JF43 & Toxic burn pits & 3.41 & 4.09 \\
\hline & JF33 & Prototype building & 3.32 & 3.04 \\
\hline & JF23 & Riot control pit & 1.47 & 1.91 \\
\hline & JF13 & Riot control pit & 1.83 & 2.54 \\
\hline & JF113 & White phosphorus pit & 1.80 & 2.27 \\
\hline & $\mathrm{JF} 93$ & White phosphorus pit & 2.76 & 6.19 \\
\hline \multicolumn{5}{|c|}{ Mean error $(\mathrm{ft})=0.77$} \\
\hline \multicolumn{5}{|c|}{ Mean absolute error $(\mathrm{ft})=0.87$} \\
\hline \multicolumn{5}{|c|}{ Root mean squared error $(\mathrm{ft})=1.37$} \\
\hline \multirow[t]{7}{*}{ Confined aquifer } & JF61 & Toxic burn pits & 1.24 & 1.17 \\
\hline & JF41 & Toxic burn pits & 1.11 & 1.17 \\
\hline & $\mathrm{JF} 31$ & Prototype building & 0.95 & 1.17 \\
\hline & $\mathrm{JF} 21$ & Riot control pit & 1.04 & 1.17 \\
\hline & JF11 & Riot control pit & 1.05 & 1.17 \\
\hline & JF111 & White phosphorus pit & 1.07 & 1.17 \\
\hline & JF91 & White phosphorus pit & 1.09 & 1.17 \\
\hline \multicolumn{5}{|c|}{ Mean error $(f t)=0.09$} \\
\hline \multicolumn{5}{|c|}{ Mean absolute error $(f t)=0.11$} \\
\hline \multicolumn{5}{|c|}{ Root mean squared error $(\mathrm{ft})=0.12$} \\
\hline
\end{tabular}

Note: "1993 Water Year Mean Head" was determined by averaging data from continuous head recorders maintained by the USGS. The period of record is September 1992 through October 1993. 
TABLE B.3 Calibration Statistics for J-Field Wells: Model Run 18

\section{Model run attributes}

Horizontal hydraulic conductivity of layer $1(\mathrm{ft} / \mathrm{d})=5.3$

Horizontal hydraulic conductivity of layer $2(\mathrm{ft} / \mathrm{d})=0.0015$

Horizontal hydraulic conductivity of layer $3(\mathrm{ft} / \mathrm{d})=390$

Recharge (in./yr) $=12$

\begin{tabular}{lllll} 
Well & \multicolumn{1}{c}{$\begin{array}{c}\text { Nearby } \\
\text { Name }\end{array}$} & $\begin{array}{c}\text { Water Year } \\
\text { Mean Head } \\
\text { (ft MSL) }\end{array}$ & $\begin{array}{c}\text { Model Run } \\
\text { Head } \\
\text { (ft MSL) }\end{array}$ \\
\hline \multirow{3}{*}{ Surficial aquifer } & & & & \\
& $\mathrm{JF63}$ & Toxic burn pits & 2.77 & 2.84 \\
& $\mathrm{JF} 43$ & Toxic burn pits & 3.41 & 4.45 \\
& $\mathrm{JF33}$ & Prototype building & 3.32 & 3.31 \\
& $\mathrm{JF} 23$ & Riot control pit & 1.47 & 2.05 \\
& $\mathrm{JF} 13$ & Riot control pit & 1.83 & 2.76 \\
& $\mathrm{JF} 113$ & White phosphorus pit & 1.80 & 2.45 \\
& $\mathrm{JF} 93$ & White phosphorus pit & 2.76 & 6.85
\end{tabular}

Mean error $(\mathrm{ft})=1.05$

Mean absolute error $(\mathrm{ft})=1.05$

Root mean squared error $(\mathrm{ft})=1.67$

$\begin{array}{lllll}\text { Confined aquifer } & \text { JF61 } & \text { Toxic burn pits } & 1.24 & 1.19 \\ & \text { JF41 } & \text { Toxic burn pits } & 1.11 & 1.19 \\ \text { JF31 } & \text { Prototype building } & 0.95 & 1.19 \\ \text { JF21 } & \text { Riot control pit } & 1.04 & 1.19 \\ \text { JF11 } & \text { Riot control pit } & 1.05 & 1.19 \\ \text { JF111 } & \text { White phosphorus pit } & 1.07 & 1.20 \\ & \text { JF91 } & \text { White phosphorus pit } & 1.09 & 1.20\end{array}$

Mean error $(\mathrm{ft})=0.11$

Mean absolute error $(\mathrm{ft})=0.13$

Root mean squared error $(\mathrm{ft})=0.14$

Note: "1993 Water Year Mean Head" was determined by averaging data from continuous head recorders maintained by the USGS. The period of record is September 1992 through October 1993. 
TABLE B.4 Calibration Statistics for J-Field Wells: Model Run 19

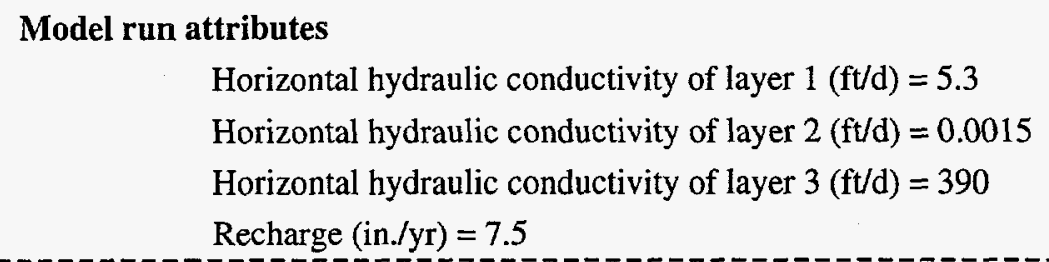

Horizontal hydraulic conductivity of layer $1(\mathrm{ft} / \mathrm{d})=5.3$

Horizontal hydraulic conductivity of layer $2(\mathrm{ft} / \mathrm{d})=0.0015$

Horizontal hydraulic conductivity of layer $3(\mathrm{ft} / \mathrm{d})=390$

Recharge (in./yr) $=7.5$

\begin{tabular}{lllll} 
Well & \multicolumn{1}{c}{$\begin{array}{c}\text { Nearby } \\
\text { Site Feature }\end{array}$} & $\begin{array}{c}1993 \\
\text { Water Year } \\
\text { Mean Head } \\
\text { (ft MSL) }\end{array}$ & $\begin{array}{c}\text { Model Run } \\
\text { Head } \\
\text { (ft MSL) }\end{array}$ \\
\hline \multirow{2}{*}{ Surficial aquifer } & & & & \\
& JF63 & Toxic burn pits & 2.77 & 2.40 \\
& JF43 & Toxic burn pits & 3.41 & 3.35 \\
& JF33 & Prototype building & 3.32 & 2.49 \\
& JF23 & Riot control pit & 1.47 & 1.64 \\
& JF13 & Riot control pit & 1.83 & 2.11 \\
& JF113 & White phosphorus pit & 1.80 & 1.89 \\
& JF93 & White phosphorus pit & 2.76 & 4.82
\end{tabular}

Mean error $(\mathrm{ft})=0.19$

Mean absolute error $(\mathrm{ft})=0.55$

Root mean squared error $(\mathrm{ft})=0.86$

$\begin{array}{lllll}\text { Confined aquifer } & \text { JF61 } & \text { Toxic burn pits } & 1.24 & 1.12 \\ & \text { JF41 } & \text { Toxic burn pits } & 1.11 & 1.12 \\ & \text { JF31 } & \text { Prototype building } & 0.95 & 1.12 \\ \text { JF21 } & \text { Riot control pit } & 1.04 & 1.12 \\ \text { JF11 } & \text { Riot control pit } & 1.05 & 1.12 \\ & \text { JF111 } & \text { White phosphorus pit } & 1.07 & 1.12 \\ \text { JF91 } & \text { White phosphorus pit } & 1.09 & 1.12\end{array}$

Mean error $(\mathrm{ft})=0.04$

Mean absolute error $(\mathrm{ft})=0.08$

Root mean squared error $(\mathrm{ft})=0.09$

Note: "1993 Water Year Mean Head" was determined by averaging data from continuous head recorders maintained by the USGS. The period of record is September 1992 through October 1993. 
TABLE B.5 Calibration Statistics for J-Field Wells: Model Run 20

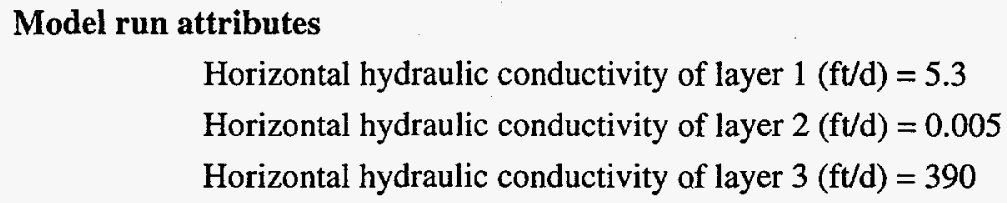

Model run attributes

Horizontal hydraulic conductivity of layer $1(\mathrm{ft} / \mathrm{d})=5.3$

Horizontal hydraulic conductivity of layer $2(\mathrm{ft} / \mathrm{d})=0.005$

Horizontal hydraulic conductivity of layer $3(\mathrm{ft} / \mathrm{d})=390$

Recharge (in./yr) $=12$

\begin{tabular}{|c|c|c|c|c|}
\hline & $\begin{array}{c}\text { Well } \\
\text { Name }\end{array}$ & $\begin{array}{c}\text { Nearby } \\
\text { Site Feature }\end{array}$ & $\begin{array}{c}1993 \\
\text { Water Year } \\
\text { Mean Head } \\
\text { (ft MSL) }\end{array}$ & $\begin{array}{c}\text { Model Run } \\
\text { Head } \\
\text { (ft MSL) }\end{array}$ \\
\hline \multirow[t]{7}{*}{ Surficial aquifer } & JF63 & Toxic burn pits & 2.77 & 2.84 \\
\hline & JF43 & Toxic burn pits & 3.41 & 4.42 \\
\hline & JF33 & Prototype building & 3.32 & 3.30 \\
\hline & $\mathrm{JF} 23$ & Riot control pit & 1.47 & 2.04 \\
\hline & JF13 & Riot control pit & 1.83 & 2.75 \\
\hline & JF113 & White phosphorus pit & 1.80 & 2.43 \\
\hline & JF93 & White phosphorus pit & 2.76 & 6.76 \\
\hline \multicolumn{5}{|c|}{ Mean error $(\mathrm{ft})=1.03$} \\
\hline \multicolumn{5}{|c|}{ Mean absolute error $(\mathrm{ft})=1.03$} \\
\hline \multicolumn{5}{|c|}{ Root mean squared error $(f t)=1.63$} \\
\hline \multirow[t]{7}{*}{ Confined aquifer } & JF61 & Toxic burn pits & 1.24 & 1.51 \\
\hline & $\mathrm{JF} 41$ & Toxic burn pits & 1.11 & 1.51 \\
\hline & $\mathrm{JF} 31$ & Prototype building & 0.95 & 1.51 \\
\hline & $\mathrm{JF} 21$ & Riot control pit & 1.04 & 1.51 \\
\hline & $\mathrm{JF} 11$ & Riot control pit & 1.05 & 1.51 \\
\hline & $J F 111$ & White phosphorus pit & 1.07 & 1.51 \\
\hline & JF91 & White phosphorus pit & 1.09 & 1.51 \\
\hline \multicolumn{5}{|c|}{ Mean error $(\mathrm{ft})=0.43$} \\
\hline \multicolumn{5}{|c|}{ Mean absolute error $(\mathrm{ft})=0.43$} \\
\hline \multicolumn{5}{|c|}{ Root mean squared error $(\mathrm{ft})=0.44$} \\
\hline
\end{tabular}

Note: "1993 Water Year Mean Head" was determined by averaging data from continuous head recorders maintained by the USGS. The period of record is September 1992 through October 1993. 
TABLE B.6 Calibration Statistics for J-Field Wells: Model Run 21

\section{Model run attributes}

Horizontal hydraulic conductivity of layer $1(\mathrm{ft} / \mathrm{d})=5.3$

Horizontal hydraulic conductivity of layer $2(\mathrm{ft} / \mathrm{d})=0.005$

Horizontal hydraulic conductivity of layer $3(\mathrm{ft} / \mathrm{d})=390$

Recharge (in./yr) $=10.5$

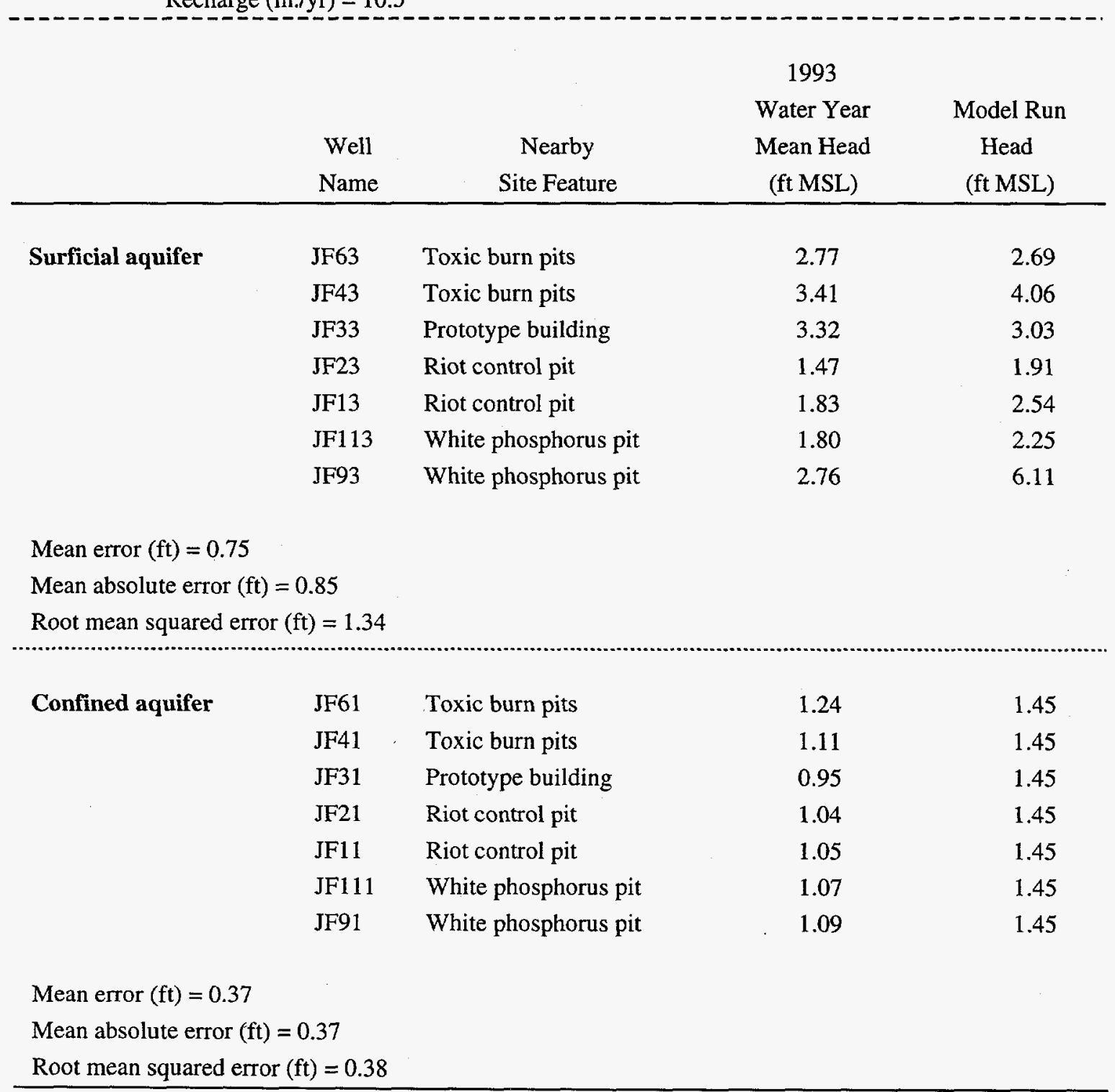

Note: "1993 Water Year Mean Head" was determined by averaging data from continuous head recorders maintained by the USGS. The period of record is September 1992 through October 1993. 
TABLE B.7 Calibration Statistics for J-Field Wells: Model Run 22

\section{Model run attributes \\ Horizontal hydraulic conductivity of layer $1(\mathrm{ft} / \mathrm{d})=5.3$ \\ Horizontal hydraulic conductivity of layer $2(\mathrm{ft} / \mathrm{d})=0.005$ \\ Horizontal hydraulic conductivity of layer $3(\mathrm{ft} / \mathrm{d})=390$ \\ Recharge (in./yr) $=9$}

\begin{tabular}{lllll} 
Well & \multicolumn{1}{c}{$\begin{array}{c}\text { Nearby } \\
\text { Site Feature }\end{array}$} & $\begin{array}{c}\text { Mater Year } \\
\text { Mean Head } \\
\text { (ft MSL) }\end{array}$ & $\begin{array}{c}\text { Model Run } \\
\text { Head } \\
\text { (ft MSL) }\end{array}$ \\
\hline \multirow{3}{*}{ Surficial aquifer } & JF63 & Toxic burn pits & 2.77 & 2.54 \\
& JF43 & Toxic burn pits & 3.41 & 3.70 \\
& JF33 & Prototype building & 3.32 & 2.75 \\
& JF23 & Riot control pit & 1.47 & 2.30 \\
& JF13 & Riot control pit & 1.83 & 2.72 \\
& JF113 & White phosphorus pit & 1.80 & 2.06 \\
& JF93 & White phosphorus pit & 2.76 & 5.44
\end{tabular}

Mean error $(\mathrm{ft})=0.59$

Mean absolute error $(\mathrm{ft})=0.82$

Root mean squared error $(\mathrm{ft})=1.15$

$\begin{array}{lllll}\text { Confined aquifer } & \text { JF61 } & \text { Toxic burn pits } & 1.24 & 1.39 \\ & \text { JF41 } & \text { Toxic burn pits } & 1.11 & 1.39 \\ & \text { JF31 } & \text { Prototype building } & 0.95 & 1.38 \\ \text { JF21 } & \text { Riot control pit } & 1.04 & 1.38 \\ \text { JF11 } & \text { Riot control pit } & 1.05 & 1.38 \\ \text { JF111 } & \text { White phosphorus pit } & 1.07 & 1.39 \\ & \text { JF91 } & \text { White phosphorus pit } & 1.09 & 1.39\end{array}$

Mean error $(\mathrm{ft})=0.31$

Mean absolute error $(\mathrm{ft})=0.31$

Root mean squared error $(\mathrm{ft})=0.32$

Note: "1993 Water Year Mean Head" was determined by averaging data from continuous head recorders maintained by the USGS. The period of record is September 1992 through October 1993. 
TABLE B.8 Calibration Statistics for J-Field Wells: Model Run 23

\section{Model run attributes \\ Horizontal hydraulic conductivity of layer $1(\mathrm{ft} / \mathrm{d})=5.3$ \\ Horizontal hydraulic conductivity of layer $2(\mathrm{ft} / \mathrm{d})=0.005$ \\ Horizontal hydraulic conductivity of layer $3(\mathrm{ft} / \mathrm{d})=390$}

Recharge (in./yr) $=7.5$

\begin{tabular}{|c|c|c|c|c|}
\hline & $\begin{array}{c}\text { Well } \\
\text { Name }\end{array}$ & $\begin{array}{c}\text { Nearby } \\
\text { Site Feature }\end{array}$ & $\begin{array}{c}1993 \\
\text { Water Year } \\
\text { Mean Head } \\
\text { (ft MSL) } \\
\end{array}$ & $\begin{array}{c}\text { Model Run } \\
\text { Head } \\
\text { (ft MSL) }\end{array}$ \\
\hline \multirow[t]{7}{*}{ Surficial aquifer } & JF63 & Toxic burn pits & 2.77 & 2.39 \\
\hline & JF43 & Toxic burn pits & 3.41 & 3.33 \\
\hline & $\mathrm{JF} 33$ & Prototype building & 3.32 & 2.48 \\
\hline & $\mathrm{JF} 23$ & Riot control pit & 1.47 & 1.64 \\
\hline & $\mathrm{JF} 13$ & Riot control pit & 1.83 & 2.11 \\
\hline & JF113 & White phosphorus pit & 1.80 & 1.88 \\
\hline & JF93 & White phosphorus pit & 2.76 & 4.76 \\
\hline \multicolumn{5}{|c|}{ Mean error $(f t)=0.18$} \\
\hline \multicolumn{5}{|c|}{ Mean absolute error $(\mathrm{ft})=0.55$} \\
\hline \multicolumn{5}{|c|}{ Root mean squared error $(\mathrm{ft})=0.84$} \\
\hline \multirow[t]{7}{*}{ Confined aquifer } & JF61 & Toxic burn pits & 1.24 & 1.32 \\
\hline & JF41 & Toxic burn pits & 1.11 & 1.32 \\
\hline & $\mathrm{JF} 31$ & Prototype building & 0.95 & 1.32 \\
\hline & $\mathrm{JF} 21$ & Riot control pit & 1.04 & 1.32 \\
\hline & $\mathrm{JF} 11$ & Riot control pit & 1.05 & 1.32 \\
\hline & JF111 & White phosphorus pit & 1.07 & 1.32 \\
\hline & JF91 & White phosphorus pit & 1.09 & 1.32 \\
\hline \multicolumn{5}{|c|}{ Mean error $(\mathrm{ft})=0.24$} \\
\hline \multicolumn{5}{|c|}{ Mean absolute error $(\mathrm{ft})=0.24$} \\
\hline \multicolumn{5}{|c|}{ Root mean squared error $(\mathrm{ft})=0.25$} \\
\hline
\end{tabular}

Note: "1993 Water Year Mean Head" was determined by averaging data from continuous head recorders maintained by the USGS. The period of record is September 1992 through October 1993. 
TABLE B.9 Calibration Statistics for J-Field Wells: Model Run 24

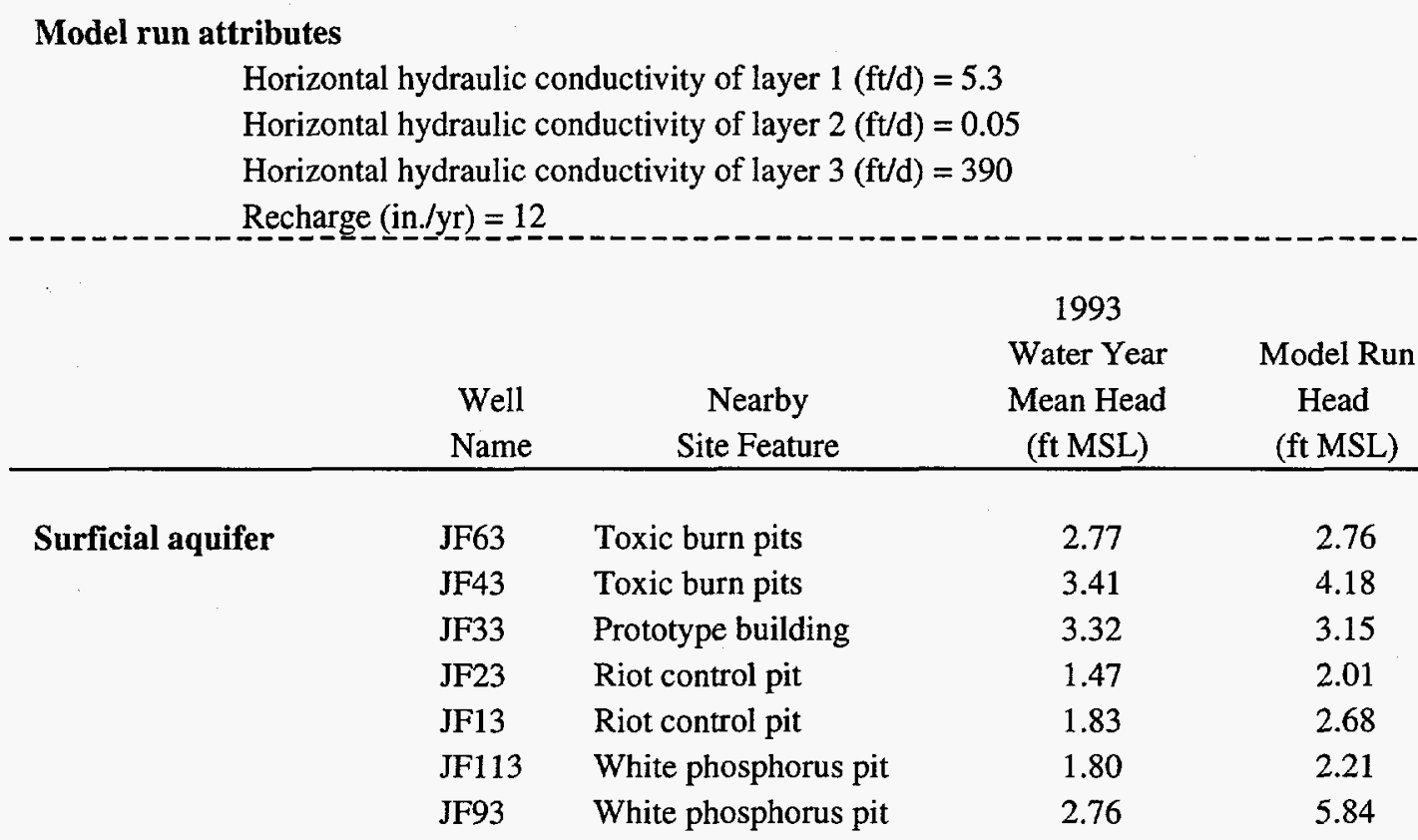

Mean error $(\mathrm{ft})=0.78$

Mean absolute error $(\mathrm{ft})=0.83$

Root mean squared error $(\mathrm{ft})=1.27$

$\begin{array}{lllll}\text { Confined aquifer } & \text { JF61 } & \text { Toxic burn pits } & 1.24 & 1.87 \\ & \text { JF41 } & \text { Toxic burn pits } & 1.11 & 1.87 \\ & \text { JF31 } & \text { Prototype building } & 0.95 & 1.86 \\ \text { JF21 } & \text { Riot control pit } & 1.04 & 1.85 \\ & \text { JF11 } & \text { Riot control pit } & 1.05 & 1.85 \\ \text { JF111 } & \text { White phosphorus pit } & 1.07 & 1.89 \\ & \text { JF91 } & \text { White phosphorus pit } & 1.09 & 1.89\end{array}$

Mean error $(\mathrm{ft})=0.79$

Mean absolute error $(\mathrm{ft})=0.79$

Root mean squared error $(\mathrm{ft})=0.79$

Note: "1993 Water Year Mean Head" was determined by averaging data from continuous head recorders maintained by the USGS. The period of record is September 1992 through October 1993. 
TABLE B.10 Calibration Statistics for J-Field Wells: Model Run 25

\section{Model run attributes}

Horizontal hydraulic conductivity of layer $1(\mathrm{ft} / \mathrm{d})=5.3$

Horizontal hydraulic conductivity of layer $2(\mathrm{ft} / \mathrm{d})=0.05$

Horizontal hydraulic conductivity of layer $3(\mathrm{ft} / \mathrm{d})=390$

Recharge (in./yr) $=9$

\begin{tabular}{|c|c|c|c|c|}
\hline & $\begin{array}{c}\text { Well } \\
\text { Name }\end{array}$ & $\begin{array}{c}\text { Nearby } \\
\text { Site Feature }\end{array}$ & $\begin{array}{c}1993 \\
\text { Water Year } \\
\text { Mean Head } \\
\text { (ft MSL) } \\
\end{array}$ & $\begin{array}{c}\text { Model Run } \\
\text { Head } \\
\text { (ft MSL) } \\
\end{array}$ \\
\hline \multirow[t]{7}{*}{ Surficial aquifer } & JF63 & Toxic burn pits & 2.77 & 2.48 \\
\hline & $\mathrm{JF} 43$ & Toxic burn pits & 3.41 & 3.51 \\
\hline & JF33 & Prototype building & 3.32 & 2.64 \\
\hline & $\mathrm{JF} 23$ & Riot control pit & 1.47 & 1.75 \\
\hline & JF13 & Riot control pit & 1.83 & 2.27 \\
\hline & JF113 & White phosphorus pit & 1.80 & 1.89 \\
\hline & JF93 & White phosphorus pit & 2.76 & 4.70 \\
\hline \multicolumn{5}{|c|}{ Mean error $(\mathrm{ft})=0.27$} \\
\hline \multicolumn{5}{|c|}{ Mean absolute error $(\mathrm{ft})=0.55$} \\
\hline \multicolumn{5}{|c|}{ Root mean squared error $(\mathrm{ft})=0.81$} \\
\hline \multirow[t]{7}{*}{ Confined aquifer } & JF61 & Toxic burn pits & 1.24 & 1.66 \\
\hline & $\mathrm{JF} 41$ & Toxic burn pits & 1.11 & 1.65 \\
\hline & JF31 & Prototype building & 0.95 & 1.65 \\
\hline & JF21 & Riot control pit & 1.04 & 1.64 \\
\hline & JF11 & Riot control pit & 1.05 & 1.64 \\
\hline & JF111 & White phosphorus pit & 1.07 & 1.66 \\
\hline & JF91 & White phosphorus pit & 1.09 & 1.67 \\
\hline \multicolumn{5}{|c|}{ Mean error $(\mathrm{ft})=0.57$} \\
\hline \multicolumn{5}{|c|}{ Mean absolute error $(\mathrm{ft})=0.57$} \\
\hline \multicolumn{5}{|c|}{ Root mean squared error $(\mathrm{ft})=0.58$} \\
\hline
\end{tabular}

Note: "1993 Water Year Mean Head" was determined by averaging data from continuous head recorders maintained by the USGS. The period of record is September 1992 through October 1993. 
TABLE B.11 Calibration Statistics for J-Field Wells: Model Run 26

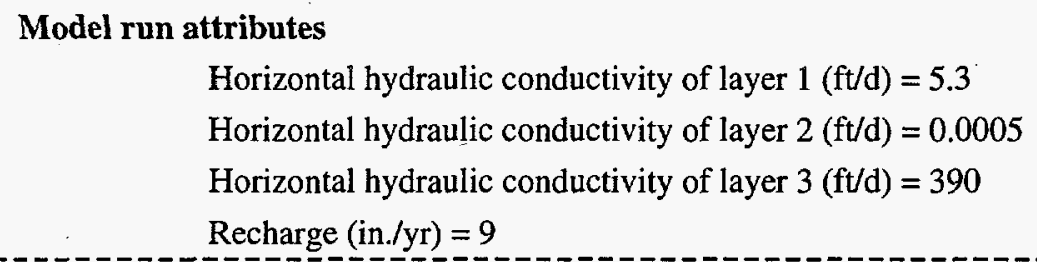

Horizontal hydraulic conductivity of layer $1(\mathrm{ft} / \mathrm{d})=5.3$

Horizontal hydraulic conductivity of layer $2(\mathrm{ft} / \mathrm{d})=0.0005$

Horizontal hydraulic conductivity of layer $3(\mathrm{ft} / \mathrm{d})=390$

Recharge (in./yr) $=9$

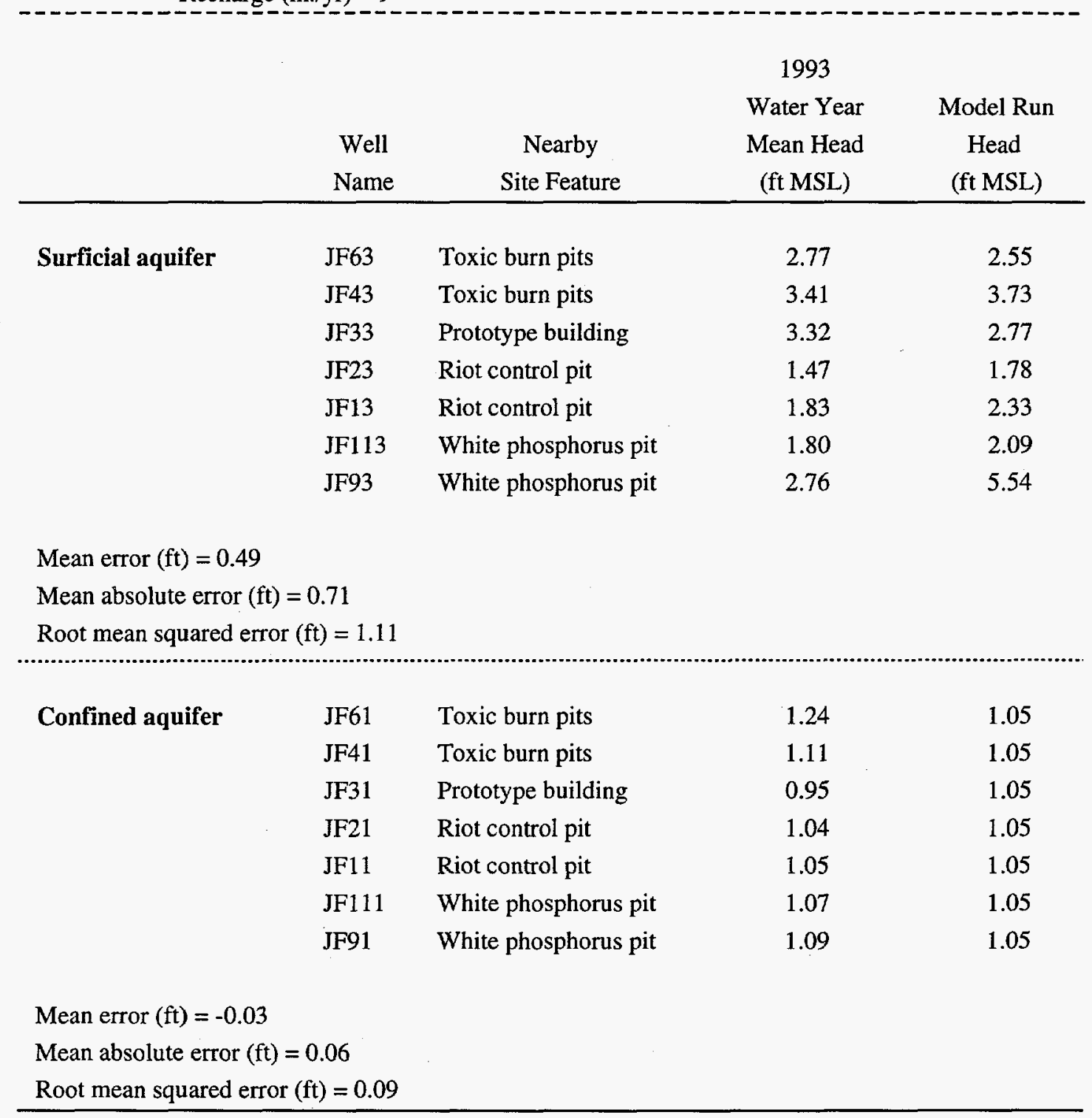

Note: "1993 Water Year Mean Head" was determined by averaging data from continuous head recorders maintained by the USGS. The period of record is September 1992 through October 1993. 
TABLE B.12 Calibration Statistics for J-Field Wells: Model Run 27

\section{Model run attributes \\ Horizontal hydraulic conductivity of layer $1(\mathrm{ft} / \mathrm{d})=5.3$ \\ Horizontal hydraulic conductivity of layer $2(\mathrm{ft} / \mathrm{d})=0.0005$ \\ Horizontal hydraulic conductivity of layer $3(\mathrm{ft} / \mathrm{d})=390$ \\ Recharge (in./yr) $=12$}

\begin{tabular}{|c|c|c|c|c|}
\hline & $\begin{array}{c}\text { Well } \\
\text { Name }\end{array}$ & $\begin{array}{c}\text { Nearby } \\
\text { Site Feature }\end{array}$ & $\begin{array}{c}1993 \\
\text { Water Year } \\
\text { Mean Head } \\
\text { (ft MSL) }\end{array}$ & $\begin{array}{l}\text { Model Run } \\
\text { Head } \\
\text { (ft MSL) }\end{array}$ \\
\hline \multirow[t]{7}{*}{ Surficial aquifer } & JF63 & Toxic burn pits & 2.77 & 2.85 \\
\hline & $\mathrm{JF} 43$ & Toxic burn pits & 3.41 & 4.45 \\
\hline & JF33 & Prototype building & 3.32 & 3.32 \\
\hline & $\mathrm{JF} 23$ & Riot control pit & 1.47 & 2.05 \\
\hline & $\mathrm{JF} 13$ & Riot control pit & 1.83 & 2.76 \\
\hline & JF113 & White phosphorus pit & 1.80 & 2.46 \\
\hline & JF93 & White phosphorus pit & 2.76 & 6.88 \\
\hline \multicolumn{5}{|c|}{ Mean error $(\mathrm{ft})=1.06$} \\
\hline \multicolumn{5}{|c|}{ Mean absolute error $(\mathrm{ft})=1.06$} \\
\hline \multicolumn{5}{|c|}{ Root mean squared error $(\mathrm{ft})=1.68$} \\
\hline \multirow[t]{7}{*}{ Confined aquifer } & JF61 & Toxic burn pits & 1.24 & 1.07 \\
\hline & $\mathrm{JF} 41$ & Toxic burn pits & 1.11 & 1.07 \\
\hline & $\mathrm{JF} 31$ & Prototype building & 0.95 & 1.07 \\
\hline & $\mathrm{JF} 21$ & Riot control pit & 1.04 & 1.07 \\
\hline & JF11 & Riot control pit & 1.05 & 1.07 \\
\hline & JF111 & White phosphorus pit & 1.07 & 1.07 \\
\hline & JF91 & White phosphorus pit & 1.09 & 1.07 \\
\hline \multicolumn{5}{|c|}{ Mean error $(\mathrm{ft})=-0.01$} \\
\hline \multicolumn{5}{|c|}{ Mean absolute error $(\mathrm{ft})=0.06$} \\
\hline \multicolumn{5}{|c|}{ Root mean squared error $(\mathrm{ft})=0.08$} \\
\hline
\end{tabular}

Note: "1993 Water Year Mean Head" was determined by averaging data from continuous head recorders maintained by the USGS. The period of record is September 1992 through October 1993. 
C-1

APPENDIX C:

MODEL SENSITIVITY SUMMARIES 
C-2 
TABLE C.1 Sensitivity Analysis for J-Field Wells: Model Run 28

Model parameter changed from calibrated value

Horizontal hydraulic conductivity of surficial aquifer doubled, from 5.3 to $10.6 \mathrm{ft} / \mathrm{d}$

\begin{tabular}{|c|c|c|c|c|}
\hline & $\begin{array}{c}\text { Well } \\
\text { Name }\end{array}$ & $\begin{array}{c}\text { Nearby } \\
\text { Site Feature }\end{array}$ & $\begin{array}{l}\text { Cell Value from } \\
\text { Calibrated Model } \\
\text { (ft MSL) }\end{array}$ & $\begin{array}{c}\text { Model Run } \\
\text { Head } \\
\text { (ft MSL) }\end{array}$ \\
\hline \multirow[t]{7}{*}{ Surficial aquifer } & JF63 & Toxic burn pits & 2.70 & 2.24 \\
\hline & $\mathrm{JF} 43$ & Toxic burn pits & 4.09 & 2.86 \\
\hline & $\mathrm{JF} 33$ & Prototype building & 3.04 & 2.09 \\
\hline & $\mathrm{JF} 23$ & Riot control pit & 1.91 & 1.44 \\
\hline & JF13 & Riot control pit & 2.54 & 1.79 \\
\hline & JF113 & White phosphorus pit & 2.27 & 1.64 \\
\hline & JF93 & White phosphorus pit & 6.19 & 3.89 \\
\hline \multicolumn{5}{|c|}{ Mean error $(f t)=-0.97$} \\
\hline \multicolumn{5}{|c|}{ Mean absolute error $(\mathrm{ft})=0.97$} \\
\hline \multicolumn{5}{|c|}{ Root mean squared error $(\mathrm{ft})=1.14$} \\
\hline \multirow[t]{7}{*}{ Confined aquifer } & JF61 & Toxic burn pits & 1.17 & 1.10 \\
\hline & $\mathrm{JF} 41$ & Toxic burn pits & 1.17 & 1.10 \\
\hline & JF31 & Prototype building & 1.17 & 1.10 \\
\hline & $\mathrm{JF} 21$ & Riot control pit & 1.17 & 1.10 \\
\hline & $\mathrm{JF} 11$ & Riot control pit & 1.17 & 1.10 \\
\hline & $\mathrm{JF} 111$ & White phosphorus pit & 1.17 & 1.10 \\
\hline & JF91 & White phosphorus pit & 1.17 & 1.10 \\
\hline \multicolumn{5}{|c|}{ Mean error $(\mathrm{ft})=-0.07$} \\
\hline \multicolumn{5}{|c|}{ Mean absolute error $(\mathrm{ft})=0.07$} \\
\hline \multicolumn{5}{|c|}{ Root mean squared error $(\mathrm{ft})=0.07$} \\
\hline
\end{tabular}


TABLE C.2 Sensitivity Analysis for J-Field Wells: Model Run 29

Model parameter changed from calibrated value

Horizontal hydraulic conductivity of surficial aquifer increased one order of magnitude, from 5.3 to $53 \mathrm{ft} / \mathrm{d}$

\begin{tabular}{|c|c|c|c|c|}
\hline & $\begin{array}{l}\text { Well } \\
\text { Name }\end{array}$ & $\begin{array}{c}\text { Nearby } \\
\text { Site Feature }\end{array}$ & $\begin{array}{l}\text { Cell Value from } \\
\text { Calibrated Model } \\
(\mathrm{ft} \text { MSL) }\end{array}$ & $\begin{array}{c}\text { Model Run } \\
\text { Head } \\
\text { (ft MSL) }\end{array}$ \\
\hline \multirow[t]{7}{*}{ Surficial aquifer } & JF63 & Toxic burn pits & 2.70 & 1.71 \\
\hline & $\mathrm{JF} 43$ & Toxic burn pits & 4.09 & 1.65 \\
\hline & JF33 & Prototype building & 3.04 & 1.24 \\
\hline & $\mathrm{JF} 23$ & Riot control pit & 1.91 & 1.03 \\
\hline & $\mathrm{JF} 13$ & Riot control pit & 2.54 & 1.12 \\
\hline & JF113 & White phosphorus pit & 2.27 & 1.08 \\
\hline & JF93 & White phosphorus pit & 6.19 & 1.72 \\
\hline \multicolumn{5}{|c|}{ Mean error $(\mathrm{ft})=-1.88$} \\
\hline \multicolumn{5}{|c|}{ Mean absolute error $(\mathrm{ft})=1.88$} \\
\hline \multicolumn{5}{|c|}{ Root mean squared error $(\mathrm{ft})=2.22$} \\
\hline \multirow[t]{7}{*}{ Confined aquifer } & $\mathrm{JF} 61$ & Toxic burn pits & 1.17 & 1.02 \\
\hline & $\mathrm{JF} 41$ & Toxic burn pits & 1.17 & 1.02 \\
\hline & JF31 & Prototype building & 1.17 & 1.02 \\
\hline & $\mathrm{JF} 21$ & Riot control pit & 1.17 & 1.02 \\
\hline & JF11 & Riot control pit & 1.17 & 1.02 \\
\hline & JF111 & White phosphorus pit & 1.17 & 1.02 \\
\hline & JF91 & White phosphorus pit & 1.17 & 1.02 \\
\hline \multicolumn{5}{|c|}{ Mean error $(\mathrm{ft})=-0.15$} \\
\hline \multicolumn{5}{|c|}{ Mean absolute error $(\mathrm{ft})=0.15$} \\
\hline \multicolumn{5}{|c|}{ Root mean squared error $(\mathrm{ft})=0.15$} \\
\hline
\end{tabular}


TABLE C.3 Sensitivity Analysis for J-Field Wells: Model Run 30

\section{Model parameter changed from calibrated value}

Horizontal hydraulic conductivity of surficial aquifer halved, from 5.3 to $2.65 \mathrm{ft} / \mathrm{d}$

\begin{tabular}{|c|c|c|c|c|}
\hline & $\begin{array}{l}\text { Well } \\
\text { Name }\end{array}$ & $\begin{array}{c}\text { Nearby } \\
\text { Site Feature }\end{array}$ & $\begin{array}{l}\text { Cell Value from } \\
\text { Calibrated Model } \\
\text { (ft MSL) }\end{array}$ & $\begin{array}{c}\text { Model Run } \\
\text { Head } \\
\text { (ft MSL) }\end{array}$ \\
\hline \multirow[t]{7}{*}{ Surficial aquifer } & JF63 & Toxic burn pits & 2.70 & 3.51 \\
\hline & JF43 & Toxic burn pits & 4.09 & 6.31 \\
\hline & JF33 & Prototype building & 3.04 & 4.81 \\
\hline & $\mathrm{JF} 23$ & Riot control pit & 1.91 & 2.82 \\
\hline & JF13 & Riot control pit & 2.54 & 3.96 \\
\hline & JF113 & White phosphorus pit & 2.27 & 3.45 \\
\hline & JF93 & White phosphorus pit & 6.19 & 10.17 \\
\hline \multicolumn{5}{|c|}{ Mean error $(\mathrm{ft})=1.76$} \\
\hline \multicolumn{5}{|c|}{ Mean absolute error $(\mathrm{ft})=1.76$} \\
\hline \multicolumn{5}{|c|}{ Root mean squared error $(\mathrm{ft})=2.03$} \\
\hline \multirow[t]{7}{*}{ Confined aquifer } & JF61 & Toxic burn pits & 1.17 & 1.28 \\
\hline & JF41 & Toxic burn pits & 1.17 & 1.28 \\
\hline & JF31 & Prototype building & 1.17 & 1.28 \\
\hline & JF21 & Riot control pit & 1.17 & 1.28 \\
\hline & JF11 & Riot control pit & 1.17 & 1.28 \\
\hline & JF111 & White phosphorus pit & 1.17 & 1.28 \\
\hline & JF91 & White phosphorus pit & 1.17 & 1.28 \\
\hline \multicolumn{5}{|c|}{ Mean error $(\mathrm{ft})=0.11$} \\
\hline \multicolumn{5}{|c|}{ Mean absolute error $(\mathrm{ft})=0.11$} \\
\hline \multicolumn{5}{|c|}{ Root mean squared error $(\mathrm{ft})=0.11$} \\
\hline
\end{tabular}


TABLE C.4 Sensitivity Analysis for J-Field Wells: Model Run 31

Model parameter changed from calibrated value

Horizontal hydraulic conductivity of surficial aquifer decreased one order of magnitude, from 5.3 to $0.53 \mathrm{ft} / \mathrm{d}$

\begin{tabular}{|c|c|c|c|c|}
\hline & $\begin{array}{c}\text { Well } \\
\text { Name }\end{array}$ & $\begin{array}{c}\text { Nearby } \\
\text { Site Feature }\end{array}$ & $\begin{array}{c}\text { Cell Value from } \\
\text { Calibrated Model } \\
(\mathrm{ft} \mathrm{MSL})\end{array}$ & $\begin{array}{c}\text { Model Run } \\
\text { Head } \\
\text { (ft MSL) }\end{array}$ \\
\hline \multirow[t]{7}{*}{ Surficial aquifer } & JF63 & Toxic burn pits & 2.70 & 9.01 \\
\hline & $\mathrm{JF} 43$ & Toxic burn pits & 4.09 & 19.93 \\
\hline & JF33 & Prototype building & 3.04 & 16.13 \\
\hline & $\mathrm{JF} 23$ & Riot control pit & 1.91 & 9.19 \\
\hline & $\mathrm{JF} 13$ & Riot control pit & 2.54 & 13.28 \\
\hline & $\mathrm{JF} 113$ & White phosphorus pit & 2.27 & 11.29 \\
\hline & JF93 & White phosphorus pit & 6.19 & 31.75 \\
\hline \multicolumn{5}{|c|}{ Mean error $(\mathrm{ft})=12.55$} \\
\hline \multicolumn{5}{|c|}{ Mean absolute error $(\mathrm{ft})=12.55$} \\
\hline \multicolumn{5}{|c|}{ Root mean squared error $(\mathrm{ft})=13.96$} \\
\hline \multirow[t]{7}{*}{ Confined aquifer } & JF61 & Toxic burn pits & 1.17 & 1.82 \\
\hline & JF41 & Toxic burn pits & 1.17 & 1.82 \\
\hline & $\mathrm{JF} 31$ & Prototype building & 1.17 & 1.82 \\
\hline & $\mathrm{JF} 21$ & Riot control pit & 1.17 & 1.82 \\
\hline & $\mathrm{JF} 11$ & Riot control pit & 1.17 & 1.82 \\
\hline & $\mathrm{JF} 111$ & White phosphorus pit & 1.17 & 1.82 \\
\hline & JF91 & White phosphorus pit & 1.17 & 1.82 \\
\hline \multicolumn{5}{|c|}{ Mean error $(f t)=0.65$} \\
\hline \multicolumn{5}{|c|}{ Mean absolute error $(\mathrm{ft})=0.65$} \\
\hline \multicolumn{5}{|c|}{ Root mean squared error $(\mathrm{ft})=0.65$} \\
\hline
\end{tabular}


TABLE C.5 Sensitivity Analysis for J-Field Wells: Model Run 32

Model parameter changed from calibrated value

Vertical hydraulic conductivity of confining unit doubled, from 0.00015 to $0.0003 \mathrm{ft} / \mathrm{d}$

\begin{tabular}{lllll} 
& Well & \multicolumn{1}{c}{$\begin{array}{c}\text { Nearby } \\
\text { Name }\end{array}$} & $\begin{array}{c}\text { Cell Value from } \\
\text { Calibrated Model } \\
(\mathrm{ft} \text { MSL) }\end{array}$ & $\begin{array}{c}\text { Model Run } \\
\text { Head } \\
\text { (ft MSL) }\end{array}$ \\
\hline \multirow{3}{*}{ Surficial aquifer } & JF63 & Toxic burn pits & 2.70 & 2.69 \\
& JF43 & Toxic burn pits & 4.09 & 4.08 \\
& JF33 & Prototype building & 3.04 & 3.03 \\
& JF23 & Riot control pit & 1.91 & 1.91 \\
& JF13 & Riot control pit & 2.54 & 2.54 \\
& JF113 & White phosphorus pit & 2.27 & 2.26 \\
& JF93 & White phosphorus pit & 6.19 & 6.15
\end{tabular}

Mean error $(\mathrm{ft})=-0.01$

Mean absolute error $(\mathrm{ft})=0.01$

Root mean squared error $(\mathrm{ft})=0.02$

Confined aquifer

$\begin{array}{llll}\text { JF61 } & \text { Toxic burn pits } & 1.17 & 1.31 \\ \text { JF41 } & \text { Toxic burn pits } & 1.17 & 1.31 \\ \text { JF31 } & \text { Prototype building } & 1.17 & 1.31 \\ \text { JF21 } & \text { Riot control pit } & 1.17 & 1.31 \\ \text { JF11 } & \text { Riot control pit } & 1.17 & 1.31 \\ \text { JF111 } & \text { White phosphorus pit } & 1.17 & 1.31 \\ \text { JF91 } & \text { White phosphorus pit } & 1.17 & 1.31\end{array}$

Mean error $(\mathrm{ft})=0.14$

Mean absolute error $(\mathrm{ft})=0.14$

Root mean squared error $(\mathrm{ft})=0.14$ 
TABLE C.6 Sensitivity Analysis for J-Field Wells: Model Run 33

Model parameter changed from calibrated value

Vertical hydraulic conductivity of confining unit increased one order of magnitude, from 0.00015 to $0.0015 \mathrm{ft} / \mathrm{d}$

\begin{tabular}{|c|c|c|c|c|}
\hline & $\begin{array}{l}\text { Well } \\
\text { Name }\end{array}$ & $\begin{array}{c}\text { Nearby } \\
\text { Site Feature }\end{array}$ & $\begin{array}{l}\text { Cell Value from } \\
\text { Calibrated Model } \\
\text { (ft MSL) }\end{array}$ & $\begin{array}{l}\text { Model Run } \\
\text { Head } \\
\text { (ft MSL) }\end{array}$ \\
\hline \multirow[t]{7}{*}{ Surficial aquifer } & JF63 & Toxic burn pits & 2.70 & 2.67 \\
\hline & $\mathrm{JF} 43$ & Toxic burn pits & 4.09 & 4.01 \\
\hline & JF33 & Prototype building & 3.04 & 3.00 \\
\hline & $\mathrm{JF} 23$ & Riot control pit & 1.91 & 1.90 \\
\hline & $\mathrm{JF} 13$ & Riot control pit & 2.54 & 2.53 \\
\hline & JF113 & White phosphorus pit & 2.27 & 2.20 \\
\hline & JF93 & White phosphorus pit & 6.19 & 5.90 \\
\hline \multicolumn{5}{|c|}{ Mean error $(f t)=-0.08$} \\
\hline \multicolumn{5}{|c|}{ Mean absolute error $(\mathrm{ft})=0.08$} \\
\hline \multicolumn{5}{|c|}{ Root mean squared error $(\mathrm{ft})=0.12$} \\
\hline \multirow[t]{7}{*}{ Confined aquifer } & JF61 & Toxic burn pits & 1.17 & 1.76 \\
\hline & JF41 & Toxic burn pits & 1.17 & 1.76 \\
\hline & JF31 & Prototype building & 1.17 & 1.76 \\
\hline & JF21 & Riot control pit & 1.17 & 1.76 \\
\hline & JF11 & Riot control pit & 1.17 & 1.76 \\
\hline & JF111 & White phosphorus pit & 1.17 & 1.76 \\
\hline & JF91 & White phosphorus pit & 1.17 & 1.76 \\
\hline \multicolumn{5}{|c|}{ Mean error $(\mathrm{ft})=0.59$} \\
\hline \multicolumn{5}{|c|}{ Mean absolute error $(\mathrm{ft})=0.59$} \\
\hline \multicolumn{5}{|c|}{ Root mean squared error $(\mathrm{ft})=0.59$} \\
\hline
\end{tabular}


TABLE C.7 Sensitivity Analysis for J-Field Wells: Model Run 34

Model parameter changed from calibrated value

Vertical hydraulic conductivity of confining unit halved, from 0.00015 to $0.000075 \mathrm{ft} / \mathrm{d}$

\begin{tabular}{|c|c|c|c|c|}
\hline & $\begin{array}{c}\text { Well } \\
\text { Name }\end{array}$ & $\begin{array}{c}\text { Nearby } \\
\text { Site Feature }\end{array}$ & $\begin{array}{l}\text { Cell Value from } \\
\text { Calibrated Model } \\
\text { (ft MSL) }\end{array}$ & $\begin{array}{c}\text { Model Run } \\
\text { Head } \\
\text { (ft MSL) }\end{array}$ \\
\hline \multirow[t]{7}{*}{ Surficial aquifer } & $\mathrm{JF} 63$ & Toxic burn pits & 2.70 & 2.70 \\
\hline & JF43 & Toxic burn pits & 4.09 & 4.09 \\
\hline & $\mathrm{JF} 33$ & Prototype building & 3.04 & 3.04 \\
\hline & $\mathrm{JF} 23$ & Riot control pit & 1.91 & 1.91 \\
\hline & $\mathrm{JF} 13$ & Riot control pit & 2.54 & 2.55 \\
\hline & $\mathrm{JF} 113$ & White phosphorus pit & 2.27 & 2.27 \\
\hline & JF93 & White phosphorus pit & 6.19 & 6.20 \\
\hline
\end{tabular}

Mean error $(\mathrm{ft})=0.00$

Mean absolute error $(\mathrm{ft})=0.00$

Root mean squared error $(\mathrm{ft})=0.01$

$\begin{array}{lllll}\text { Confined aquifer } & \text { JF61 } & \text { Toxic burn pits } & 1.17 & 1.09 \\ & \text { JF41 } & \text { Toxic burn pits } & 1.17 & 1.09 \\ \text { JF31 } & \text { Prototype building } & 1.17 & 1.09 \\ \text { JF21 } & \text { Riot control pit } & 1.17 & 1.09 \\ \text { JF11 } & \text { Riot control pit } & 1.17 & 1.09 \\ \text { JF111 } & \text { White phosphorus pit } & 1.17 & 1.09 \\ & \text { JF91 } & \text { White phosphorus pit } & 1.17 & 1.09\end{array}$

Mean error $(\mathrm{ft})=-0.08$

Mean absolute error $(\mathrm{ft})=0.08$

Root mean squared error $(\mathrm{ft})=0.08$ 
TABLE C.8 Sensitivity Analysis for J-Field Wells: Model Run 35

Model parameter changed from calibrated value

Vertical hydraulic conductivity of confining unit decreased one order of magnitude, from 0.00015 to $0.000015 \mathrm{ft} / \mathrm{d}$

\begin{tabular}{|c|c|c|c|c|}
\hline & $\begin{array}{c}\text { Well } \\
\text { Name }\end{array}$ & $\begin{array}{c}\text { Nearby } \\
\text { Site Feature }\end{array}$ & $\begin{array}{c}\text { Cell Value from } \\
\text { Calibrated Model } \\
(\mathrm{ft} \text { MSL) }\end{array}$ & $\begin{array}{c}\text { Model Run } \\
\text { Head } \\
\text { (ft MSL) }\end{array}$ \\
\hline \multirow[t]{7}{*}{ Surficial aquifer } & JF63 & Toxic burn pits & 2.70 & 2.70 \\
\hline & JF43 & Toxic burn pits & 4.09 & 4.09 \\
\hline & JF33 & Prototype building & 3.04 & 3.05 \\
\hline & $\mathrm{JF} 23$ & Riot control pit & 1.91 & 1.91 \\
\hline & $\mathrm{JF} 13$ & Riot control pit & 2.54 & 2.55 \\
\hline & JF113 & White phosphorus pit & 2.27 & 2.27 \\
\hline & JF93 & White phosphorus pit & 6.19 & 6.22 \\
\hline \multicolumn{5}{|c|}{ Mean error $(\mathrm{ft})=0.01$} \\
\hline \multicolumn{5}{|c|}{ Mean absolute error $(\mathrm{ft})=0.01$} \\
\hline \multicolumn{5}{|c|}{ Root mean squared error $(\mathrm{ft})=0.01$} \\
\hline \multirow[t]{7}{*}{ Confined aquifer } & JF61 & Toxic burn pits & 1.17 & 1.00 \\
\hline & $\mathrm{JF} 41$ & Toxic burn pits & 1.17 & 1.00 \\
\hline & $\mathrm{JF} 31$ & Prototype building & 1.17 & 1.00 \\
\hline & JF21 & Riot control pit & 1.17 & 1.00 \\
\hline & $\mathrm{JF} 11$ & Riot control pit & 1.17 & 1.00 \\
\hline & JF111 & White phosphorus pit & 1.17 & 1.00 \\
\hline & JF91 & White phosphorus pit & 1.17 & 1.00 \\
\hline \multicolumn{5}{|c|}{ Mean error $(f t)=-0.17$} \\
\hline \multicolumn{5}{|c|}{ Mean absolute error $(\mathrm{ft})=0.17$} \\
\hline \multicolumn{5}{|c|}{ Root mean squared error $(\mathrm{ft})=0.17$} \\
\hline
\end{tabular}




\section{C-11}

TABLE C.9 Sensitivity Analysis for J-Field Wells: Model Run 36

\section{Model parameter changed from calibrated value}

Horizontal hydraulic conductivity of confined aquifer doubled, from 390 to $780 \mathrm{ft} / \mathrm{d}$

\begin{tabular}{|c|c|c|c|c|}
\hline & $\begin{array}{l}\text { Well } \\
\text { Name }\end{array}$ & $\begin{array}{c}\text { Nearby } \\
\text { Site Feature }\end{array}$ & $\begin{array}{l}\text { Cell Value from } \\
\text { Calibrated Model } \\
\text { (ft MSL) }\end{array}$ & $\begin{array}{c}\text { Model Run } \\
\text { Head } \\
\text { (ft MSL) }\end{array}$ \\
\hline \multirow[t]{7}{*}{ Surficial aquifer } & JF63 & Toxic burn pits & 2.70 & 2.70 \\
\hline & JF43 & Toxic burn pits & 4.09 & 4.09 \\
\hline & $\mathrm{JF} 33$ & Prototype building & 3.04 & 3.10 \\
\hline & $\mathrm{JF} 23$ & Riot control pit & 1.91 & 1.91 \\
\hline & JF13 & Riot control pit & 2.54 & 2.54 \\
\hline & JF113 & White phosphorus pit & 2.27 & 2.27 \\
\hline & JF93 & White phosphorus pit & 6.19 & 6.19 \\
\hline \multicolumn{5}{|c|}{ Mean error $(\mathrm{ft})=0.01$} \\
\hline \multicolumn{5}{|c|}{ Mean absolute error $(\mathrm{ft})=0.01$} \\
\hline \multicolumn{5}{|c|}{ Root mean squared error $(\mathrm{ft})=0.02$} \\
\hline \multirow[t]{7}{*}{ Confined aquifer } & JF61 & Toxic burn pits & 1.17 & 1.09 \\
\hline & JF41 & Toxic burn pits & 1.17 & 1.09 \\
\hline & JF31 & Prototype building & 1.17 & 1.09 \\
\hline & $\mathrm{JF} 21$ & Riot control pit & 1.17 & 1.09 \\
\hline & $\mathrm{JF} 11$ & Riot control pit & 1.17 & 1.09 \\
\hline & $\mathrm{JF} 111$ & White phosphorus pit & 1.17 & 1.09 \\
\hline & JF91 & White phosphorus pit & 1.17 & 1.09 \\
\hline \multicolumn{5}{|c|}{ Mean error $(\mathrm{ft})=-0.08$} \\
\hline \multicolumn{5}{|c|}{ Mean absolute error $(\mathrm{ft})=0.08$} \\
\hline \multicolumn{5}{|c|}{ Root mean squared error $(\mathrm{ft})=0.08$} \\
\hline
\end{tabular}


TABLE C.10 Sensitivity Analysis for J-Field Wells: Model Run 37

Model parameter changed from calibrated value

Horizontal hydraulic conductivity of confined aquifer increased one order of magnitude, from 390 to $3,900 \mathrm{ft} / \mathrm{d}$

\begin{tabular}{|c|c|c|c|c|}
\hline & $\begin{array}{c}\text { Well } \\
\text { Name }\end{array}$ & $\begin{array}{c}\text { Nearby } \\
\text { Site Feature }\end{array}$ & $\begin{array}{c}\text { Cell Value from } \\
\text { Calibrated Model } \\
(\mathrm{ft} \mathrm{MSL})\end{array}$ & $\begin{array}{l}\text { Model Run } \\
\text { Head } \\
\text { (ft MSL) }\end{array}$ \\
\hline \multirow[t]{7}{*}{ Surficial aquifer } & JF63 & Toxic burn pits & 2.70 & 2.70 \\
\hline & JF43 & Toxic burn pits & 4.09 & 4.08 \\
\hline & JF33 & Prototype building & 3.04 & 3.04 \\
\hline & $\mathrm{JF} 23$ & Riot control pit & 1.91 & 1.91 \\
\hline & JF13 & Riot control pit & 2.54 & 2.54 \\
\hline & $\mathrm{JF} 113$ & White phosphorus pit & 2.27 & 2.27 \\
\hline & JF93 & White phosphorus pit & 6.19 & 6.19 \\
\hline \multicolumn{5}{|c|}{ Mean error $(f t)=0.00$} \\
\hline \multicolumn{5}{|c|}{ Mean absolute error $(\mathrm{ft})=0.00$} \\
\hline \multicolumn{5}{|c|}{ Root mean squared error $(\mathrm{ft})=0.00$} \\
\hline \multirow[t]{7}{*}{ Confined aquifer } & JF61 & Toxic burn pits & 1.17 & 1.00 \\
\hline & JF41 & Toxic burn pits & 1.17 & 1.00 \\
\hline & JF31 & Prototype building & 1.17 & 1.00 \\
\hline & $\mathrm{JF} 21$ & Riot control pit & 1.17 & 1.00 \\
\hline & JF11 & Riot control pit & 1.17 & 1.00 \\
\hline & $\mathrm{JF} 111$ & White phosphorus pit & 1.17 & 1.00 \\
\hline & JF91 & White phosphorus pit & 1.17 & 1.00 \\
\hline \multicolumn{5}{|c|}{ Mean error $(\mathrm{ft})=-0.17$} \\
\hline \multicolumn{5}{|c|}{ Mean absolute error $(\mathrm{ft})=0.17$} \\
\hline \multicolumn{5}{|c|}{ Root mean squared error $(\mathrm{ft})=0.17$} \\
\hline
\end{tabular}


TABLE C.11 Sensitivity Analysis for J-Field Wells: Model Run 38

Model parameter changed from calibrated value

Horizontal hydraulic conductivity of confined aquifer halved, from 390 to $195 \mathrm{ft} / \mathrm{d}$

\begin{tabular}{|c|c|c|c|c|}
\hline & $\begin{array}{c}\text { Well } \\
\text { Name }\end{array}$ & $\begin{array}{c}\text { Nearby } \\
\text { Site Feature }\end{array}$ & $\begin{array}{c}\text { Cell Value from } \\
\text { Calibrated Model } \\
\text { (ft MSL) }\end{array}$ & $\begin{array}{c}\text { Model Run } \\
\text { Head } \\
\text { (ft MSL) }\end{array}$ \\
\hline \multirow[t]{7}{*}{ Surficial aquifer } & JF63 & Toxic burn pits & 2.70 & 2.70 \\
\hline & JF43 & Toxic burn pits & 4.09 & 4.09 \\
\hline & $\mathrm{JF} 33$ & Prototype building & 3.04 & 3.10 \\
\hline & JF23 & Riot control pit & 1.91 & 1.91 \\
\hline & JF13 & Riot control pit & 2.54 & 2.54 \\
\hline & $\mathrm{JF} 113$ & White phosphorus pit & 2.27 & 2.27 \\
\hline & JF93 & White phosphorus pit & 6.19 & 6.19 \\
\hline \multicolumn{5}{|c|}{ Mean error $(\mathrm{ft})=0.01$} \\
\hline \multicolumn{5}{|c|}{ Mean absolute error $(\mathrm{ft})=0.01$} \\
\hline \multicolumn{5}{|c|}{ Root mean squared error $(\mathrm{ft})=0.02$} \\
\hline \multirow[t]{7}{*}{ Confined aquifer } & $\mathrm{JF} 61$ & Toxic burn pits & 1.17 & 1.31 \\
\hline & $\mathrm{JF} 41$ & Toxic burn pits & 1.17 & 1.31 \\
\hline & JF31 & Prototype building & 1.17 & 1.31 \\
\hline & $\mathrm{JF} 21$ & Riot control pit & 1.17 & 1.31 \\
\hline & JF11 & Riot control pit & 1.17 & 1.31 \\
\hline & $\mathrm{JF} 111$ & White phosphorus pit & 1.17 & 1.31 \\
\hline & JF91 & White phosphorus pit & 1.17 & 1.31 \\
\hline \multicolumn{5}{|c|}{ Mean error $(\mathrm{ft})=0.14$} \\
\hline \multicolumn{5}{|c|}{ Mean absolute error $(\mathrm{ft})=0.14$} \\
\hline \multicolumn{5}{|c|}{ Root mean squared error $(\mathrm{ft})=0.14$} \\
\hline
\end{tabular}


TABLE C.12 Sensitivity Analysis for J-Field Wells: Model Run 39

Model parameter changed from calibrated value

Horizontal hydraulic conductivity of confined aquifer decreased one order of magnitude, from 390 to $39 \mathrm{ft} / \mathrm{d}$

\begin{tabular}{|c|c|c|c|c|}
\hline & $\begin{array}{c}\text { Well } \\
\text { Name }\end{array}$ & $\begin{array}{c}\text { Nearby } \\
\text { Site Feature }\end{array}$ & $\begin{array}{c}\text { Cell Value from } \\
\text { Calibrated Model } \\
\text { (ft MSL) }\end{array}$ & $\begin{array}{c}\text { Model Run } \\
\text { Head } \\
\text { (ft MSL) } \\
\end{array}$ \\
\hline \multirow[t]{7}{*}{ Surficial aquifer } & JF63 & Toxic burn pits & 2.70 & 2.70 \\
\hline & $\mathrm{JF} 43$ & Toxic burn pits & 4.09 & 4.09 \\
\hline & $\mathrm{JF} 33$ & Prototype building & 3.04 & 3.04 \\
\hline & $\mathrm{JF} 23$ & Riot control pit & 1.91 & 1.91 \\
\hline & $\mathrm{JF} 13$ & Riot control pit & 2.54 & 2.55 \\
\hline & JF113 & White phosphorus pit & 2.27 & 2.27 \\
\hline & JF93 & White phosphorus pit & 6.19 & 6.19 \\
\hline \multicolumn{5}{|c|}{ Mean error $(\mathrm{ft})=0.00$} \\
\hline \multicolumn{5}{|c|}{ Mean absolute error $(\mathrm{ft})=0.00$} \\
\hline \multicolumn{5}{|c|}{ Root mean squared error $(\mathrm{ft})=0.00$} \\
\hline \multirow[t]{7}{*}{ Confined aquifer } & JF61 & Toxic burn pits & 1.17 & 1.81 \\
\hline & JF41 & Toxic burn pits & 1.17 & 1.81 \\
\hline & JF31 & Prototype building & 1.17 & 1.80 \\
\hline & JF21 & Riot control pit & 1.17 & 1.80 \\
\hline & $\mathrm{JF} 11$ & Riot control pit & 1.17 & 1.80 \\
\hline & JF111 & White phosphorus pit & 1.17 & 1.81 \\
\hline & JF91 & White phosphorus pit & 1.17 & 1.81 \\
\hline \multicolumn{5}{|c|}{ Mean error $(\mathrm{ft})=0.64$} \\
\hline \multicolumn{5}{|c|}{ Mean absolute error $(\mathrm{ft})=0.64$} \\
\hline \multicolumn{5}{|c|}{ Root mean squared error $(\mathrm{ft})=0.64$} \\
\hline
\end{tabular}


TABLE C.13 Sensitivity Analysis for J-Field Wells: Model Run 40

Model parameter changed from calibrated value Recharge increased $10 \%$, from 10.5 to $11.55 \mathrm{in} . / \mathrm{yr}$

\begin{tabular}{|c|c|c|c|c|}
\hline & $\begin{array}{l}\text { Well } \\
\text { Name }\end{array}$ & $\begin{array}{c}\text { Nearby } \\
\text { Site Feature }\end{array}$ & $\begin{array}{l}\text { Cell Value from } \\
\text { Calibrated Model } \\
\quad(\mathrm{ft} \text { MSL) }\end{array}$ & $\begin{array}{c}\text { Model Run } \\
\text { Head } \\
\text { (ft MSL) }\end{array}$ \\
\hline \multirow[t]{7}{*}{ Surficial aquifer } & JF63 & Toxic burn pits & 2.70 & 2.80 \\
\hline & JF43 & Toxic burn pits & 4.09 & 4.34 \\
\hline & JF33 & Prototype building & 3.04 & 3.23 \\
\hline & JF23 & Riot control pit & 1.91 & 2.01 \\
\hline & $\mathrm{JF} 13$ & Riot control pit & 2.54 & 2.69 \\
\hline & JF113 & White phosphorus pit & 2.27 & 2.40 \\
\hline & JF93 & White phosphorus pit & 6.19 & 6.65 \\
\hline \multicolumn{5}{|c|}{ Mean error $(\mathrm{ft})=0.20$} \\
\hline \multicolumn{5}{|c|}{ Mean absolute error $(\mathrm{ft})=0.20$} \\
\hline \multicolumn{5}{|c|}{ Root mean squared error $(\mathrm{ft})=0.23$} \\
\hline \multirow[t]{7}{*}{ Confined aquifer } & JF61 & Toxic burn pits & 1.17 & 1.19 \\
\hline & $\mathrm{JF} 41$ & Toxic burn pits & 1.17 & 1.19 \\
\hline & $\mathrm{JF} 31$ & Prototype building & 1.17 & 1.19 \\
\hline & $\mathrm{JF} 21$ & Riot control pit & 1.17 & 1.19 \\
\hline & $\mathrm{JF} 11$ & Riot control pit & 1.17 & 1.19 \\
\hline & JF111 & White phosphorus pit & 1.17 & 1.19 \\
\hline & JF91 & White phosphorus pit & 1.17 & 1.19 \\
\hline \multicolumn{5}{|c|}{ Mean error $(\mathrm{ft})=0.02$} \\
\hline \multicolumn{5}{|c|}{ Mean absolute error $(\mathrm{ft})=0.02$} \\
\hline \multicolumn{5}{|c|}{ Root mean squared error $(\mathrm{ft})=0.02$} \\
\hline
\end{tabular}


TABLE C.14 Sensitivity Analysis for J-Field Wells: Model Run 41

Model parameter changed from calibrated value Recharge doubled, from 10.5 to 21 in./yr

\begin{tabular}{lllcl} 
Well & \multicolumn{1}{c}{$\begin{array}{c}\text { Nearby } \\
\text { Name }\end{array}$} & $\begin{array}{c}\text { Cell Value from } \\
\text { Calibrated Model } \\
\text { (ft MSL) }\end{array}$ & $\begin{array}{c}\text { Model Run } \\
\text { Head } \\
\text { (ft MSL) }\end{array}$ \\
\hline \multirow{3}{*}{ Surficial aquifer } & & & & \\
& JF63 & Toxic burn pits & 2.70 & 3.73 \\
& JF43 & Toxic burn pits & 4.09 & 6.55 \\
& JF33 & Prototype building & 3.04 & 4.90 \\
& JF23 & Riot control pit & 1.91 & 2.85 \\
& JF13 & Riot control pit & 2.54 & 4.01 \\
& JF113 & White phosphorus pit & 2.27 & 3.56 \\
& JF93 & White phosphorus pit & 6.19 & 10.60
\end{tabular}

Mean error $(\mathrm{ft})=1.92$

Mean absolute error $(\mathrm{ft})=1.92$

Root mean squared error $(\mathrm{ft})=2.23$

$\begin{array}{lllll}\text { Confined aquifer } & \text { JF61 } & \text { Toxic burn pits } & 1.17 & 1.33 \\ & \text { JF41 } & \text { Toxic burn pits } & 1.17 & 1.33 \\ & \text { JF31 } & \text { Prototype building } & 1.17 & 1.33 \\ \text { JF21 } & \text { Riot control pit } & 1.17 & 1.33 \\ \text { JF11 } & \text { Riot control pit } & 1.17 & 1.33 \\ \text { JF111 } & \text { White phosphorus pit } & 1.17 & 1.33 \\ & \text { JF91 } & \text { White phosphorus pit } & 1.17 & 1.33\end{array}$

Mean error $(\mathrm{ft})=0.16$

Mean absolute error $(\mathrm{ft})=0.16$

Root mean squared error $(\mathrm{ft})=0.16$ 
TABLE C.15 Sensitivity Analysis for J-Field Wells: Model Run 42

Model parameter changed from calibrated value Recharge decreased $10 \%$, from 10.5 to 9.45 in./yr

\begin{tabular}{|c|c|c|c|c|}
\hline & $\begin{array}{l}\text { Well } \\
\text { Name }\end{array}$ & $\begin{array}{c}\text { Nearby } \\
\text { Site Feature }\end{array}$ & $\begin{array}{l}\text { Cell Value from } \\
\text { Calibrated Model } \\
\text { (ft MSL) }\end{array}$ & $\begin{array}{c}\text { Model Run } \\
\text { Head } \\
\text { (ft MSL) }\end{array}$ \\
\hline \multirow[t]{7}{*}{ Surficial aquifer } & JF63 & Toxic burn pits & 2.70 & 2.59 \\
\hline & $\mathrm{JF} 43$ & Toxic burn pits & 4.09 & 3.83 \\
\hline & $\mathrm{JF} 33$ & Prototype building & 3.04 & 2.85 \\
\hline & $\mathrm{JF} 23$ & Riot control pit & 1.91 & 1.82 \\
\hline & JF13 & Riot control pit & 2.54 & 2.39 \\
\hline & JF113 & White phosphorus pit & 2.27 & 2.14 \\
\hline & JF93 & White phosphorus pit & 6.19 & 5.71 \\
\hline \multicolumn{5}{|c|}{ Mean error $(\mathrm{ft})=-0.20$} \\
\hline \multicolumn{5}{|c|}{ Mean absolute error $(\mathrm{ft})=0.20$} \\
\hline \multicolumn{5}{|c|}{ Root mean squared error $(\mathrm{ft})=0.24$} \\
\hline \multirow[t]{7}{*}{ Confined aquifer } & JF61 & Toxic burn pits & 1.17 & 1.15 \\
\hline & JF41 & Toxic burn pits & 1.17 & 1.15 \\
\hline & JF31 & Prototype building & 1.17 & 1.15 \\
\hline & JF21 & Riot control pit & 1.17 & 1.15 \\
\hline & JF11 & Riot control pit & 1.17 & 1.15 \\
\hline & JF111 & White phosphorus pit & 1.17 & 1.16 \\
\hline & JF91 & White phosphorus pit & 1.17 & 1.16 \\
\hline \multicolumn{5}{|c|}{ Mean error $(\mathrm{ft})=-0.02$} \\
\hline \multicolumn{5}{|c|}{ Mean absolute error $(\mathrm{ft})=0.02$} \\
\hline \multicolumn{5}{|c|}{ Root mean squared error $(\mathrm{ft})=0.02$} \\
\hline
\end{tabular}


TABLE C.16 Sensitivity Analysis for J-Field Wells: Model Run 43

Model parameter changed from calibrated value Recharge halved, from 10.5 to $5.25 \mathrm{in} . / \mathrm{yr}$

\begin{tabular}{|c|c|c|c|c|}
\hline & $\begin{array}{c}\text { Well } \\
\text { Name }\end{array}$ & $\begin{array}{c}\text { Nearby } \\
\text { Site Feature }\end{array}$ & $\begin{array}{l}\text { Cell Value from } \\
\text { Calibrated Model } \\
\text { (ft MSL) }\end{array}$ & $\begin{array}{c}\text { Model Run } \\
\text { Head } \\
\text { (ft MSL) }\end{array}$ \\
\hline \multirow[t]{7}{*}{ Surficial aquifer } & JF63 & Toxic burn pits & 2.70 & 2.16 \\
\hline & JF43 & Toxic burn pits & 4.09 & 2.77 \\
\hline & JF33 & Prototype building & 3.04 & 2.06 \\
\hline & $\mathrm{JF} 23$ & Riot control pit & 1.91 & 1.43 \\
\hline & $\mathrm{JF} 13$ & Riot control pit & 2.54 & 1.78 \\
\hline & JF113 & White phosphorus pit & 2.27 & $1: 60$ \\
\hline & JF93 & White phosphorus pit & 6.19 & 3.73 \\
\hline \multicolumn{5}{|c|}{ Mean error $(\mathrm{ft})=-1.03$} \\
\hline \multicolumn{5}{|c|}{ Mean absolute error $(\mathrm{ft})=1.03$} \\
\hline \multicolumn{5}{|c|}{ Root mean squared error $(\mathrm{ft})=1.21$} \\
\hline \multirow[t]{7}{*}{ Confined aquifer } & JF61 & Toxic burn pits & 1.17 & 1.09 \\
\hline & $\mathrm{JF} 41$ & Toxic burn pits & 1.17 & 1.09 \\
\hline & $\mathrm{JF} 31$ & Prototype building & 1.17 & 1.09 \\
\hline & $\mathrm{JF} 21$ & Riot control pit & 1.17 & 1.09 \\
\hline & JF11 & Riot control pit & 1.17 & 1.09 \\
\hline & $\mathrm{JF} 111$ & White phosphorus pit & 1.17 & 1.09 \\
\hline & JF91 & White phosphorus pit & 1.17 & 1.09 \\
\hline \multicolumn{5}{|c|}{ Mean error $(\mathrm{ft})=-0.08$} \\
\hline \multicolumn{5}{|c|}{ Mean absolute error $(\mathrm{ft})=0.08$} \\
\hline \multicolumn{5}{|c|}{ Root mean squared error $(\mathrm{ft})=0.08$} \\
\hline
\end{tabular}


TABLE C.17 Sensitivity Analysis for J-Field Wells: Model Run 44

Model parameter changed from calibrated value Drain conductance doubled, from 100 to $200 \mathrm{ft}^{2} / \mathrm{d}$

\begin{tabular}{|c|c|c|c|c|}
\hline & $\begin{array}{c}\text { Well } \\
\text { Name }\end{array}$ & $\begin{array}{c}\text { Nearby } \\
\text { Site Feature }\end{array}$ & $\begin{array}{l}\text { Cell Value from } \\
\text { Calibrated Model } \\
(\mathrm{ft} \text { MSL) }\end{array}$ & $\begin{array}{c}\text { Model Run } \\
\text { Head } \\
\text { (ft MSL) }\end{array}$ \\
\hline \multirow[t]{7}{*}{ Surficial aquifer } & JF63 & Toxic burn pits & 2.70 & 2.59 \\
\hline & $\mathrm{JF} 43$ & Toxic burn pits & 4.09 & 3.98 \\
\hline & $\mathrm{JF} 33$ & Prototype building & 3.04 & 3.00 \\
\hline & $\mathrm{JF} 23$ & Riot control pit & 1.91 & 1.90 \\
\hline & JF13 & Riot control pit & 2.54 & 2.52 \\
\hline & JF1 13 & White phosphorus pit & 2.27 & 2.22 \\
\hline & JF93 & White phosphorus pit & 6.19 & 5.99 \\
\hline \multicolumn{5}{|c|}{ Mean error $(\mathrm{ft})=-0.08$} \\
\hline \multicolumn{5}{|c|}{ Mean absolute error $(\mathrm{ft})=0.08$} \\
\hline \multicolumn{5}{|c|}{ Root mean squared error $(\mathrm{ft})=0.10$} \\
\hline \multirow[t]{7}{*}{ Confined aquifer } & JF61 & Toxic burn pits & 1.17 & 1.14 \\
\hline & JF41 & Toxic burn pits & 1.17 & 1.14 \\
\hline & $\mathrm{JF} 31$ & Prototype building & 1.17 & 1.14 \\
\hline & $\mathrm{JF} 21$ & Riot control pit & 1.17 & 1.14 \\
\hline & JF11 & Riot control pit & 1.17 & 1.14 \\
\hline & JF111 & White phosphorus pit & 1.17 & 1.15 \\
\hline & JF91 & White phosphorus pit & 1.17 & 1.15 \\
\hline \multicolumn{5}{|c|}{ Mean error $(\mathrm{ft})=-0.03$} \\
\hline \multicolumn{5}{|c|}{ Mean absolute error $(\mathrm{ft})=0.03$} \\
\hline \multicolumn{5}{|c|}{ Root mean squared error $(\mathrm{ft})=0.03$} \\
\hline
\end{tabular}


TABLE C.18 Sensitivity Analysis for J-Field Wells: Model Run 45

Model parameter changed from calibrated value

Drain conductance increased one order of magnitude, from 100 to $1,000 \mathrm{ft}^{2} / \mathrm{d}$

\begin{tabular}{|c|c|c|c|c|}
\hline & $\begin{array}{l}\text { Well } \\
\text { Name }\end{array}$ & $\begin{array}{c}\text { Nearby } \\
\text { Site Feature }\end{array}$ & $\begin{array}{l}\text { Cell Value from } \\
\text { Calibrated Model } \\
\text { (ft MSL) }\end{array}$ & $\begin{array}{l}\text { Model Run } \\
\text { Head } \\
\text { (ft MSL) }\end{array}$ \\
\hline \multirow[t]{7}{*}{ Surficial aquifer } & JF63 & Toxic burn pits & 2.70 & 2.48 \\
\hline & $\mathrm{JF} 43$ & Toxic burn pits & 4.09 & 3.85 \\
\hline & $\mathrm{JF} 33$ & Prototype building & 3.04 & 2.96 \\
\hline & $\mathrm{JF} 23$ & Riot control pit & 1.91 & 1.89 \\
\hline & $\mathrm{JF} 13$ & Riot control pit & 2.54 & 2.50 \\
\hline & $\mathrm{JF} 113$ & White phosphorus pit & 2.27 & 2.17 \\
\hline & JF93 & White phosphorus pit & 6.19 & 5.75 \\
\hline \multicolumn{5}{|c|}{ Mean error $(\mathrm{ft})=-0.16$} \\
\hline \multicolumn{5}{|c|}{ Mean absolute error $(\mathrm{ft})=0.16$} \\
\hline \multicolumn{5}{|c|}{ Root mean squared error $(\mathrm{ft})=0.21$} \\
\hline \multirow[t]{7}{*}{ Confined aquifer } & $\mathrm{JF} 61$ & Toxic burn pits & 1.17 & 1.11 \\
\hline & $\mathrm{JF} 41$ & Toxic burn pits & 1.17 & 1.11 \\
\hline & JF31 & Prototype building & 1.17 & 1.11 \\
\hline & $\mathrm{JF} 21$ & Riot control pit & 1.17 & 1.11 \\
\hline & $\mathrm{JF} 11$ & Riot control pit & 1.17 & 1.11 \\
\hline & JF111 & White phosphorus pit & 1.17 & 1.11 \\
\hline & JF91 & White phosphorus pit & 1.17 & 1.11 \\
\hline \multicolumn{5}{|c|}{ Mean error $(\mathrm{ft})=-0.06$} \\
\hline \multicolumn{5}{|c|}{ Mean absolute error $(\mathrm{ft})=0.06$} \\
\hline \multicolumn{5}{|c|}{ Root mean squared error $(\mathrm{ft})=0.06$} \\
\hline
\end{tabular}


TABLE C.19 Sensitivity Analysis for J-Field Wells: Model Run 46

Model parameter changed from calibrated value Drain conductance halved, from 100 to $50 \mathrm{ft}^{2} / \mathrm{d}$

\begin{tabular}{lllcl} 
Well & \multicolumn{1}{c}{$\begin{array}{c}\text { Nearby } \\
\text { Name }\end{array}$} & $\begin{array}{c}\text { Cell Value from } \\
\text { Calibrated Model } \\
(\mathrm{ft} \text { MSL) }\end{array}$ & $\begin{array}{c}\text { Model Run } \\
\text { Head } \\
\text { (ft MSL) }\end{array}$ \\
\hline \multirow{3}{*}{ Surficial aquifer } & JF63 & Toxic burn pits & 2.70 & 2.86 \\
& JF43 & Toxic burn pits & 4.09 & 4.25 \\
& JF33 & Prototype building & 3.04 & 3.10 \\
& JF23 & Riot control pit & 1.91 & 1.93 \\
& JF13 & Riot control pit & 2.54 & 2.57 \\
& JF113 & White phosphorus pit & 2.27 & 2.33 \\
& JF93 & White phosphorus pit & 6.19 & 6.46
\end{tabular}

Mean error $(\mathrm{ft})=0.11$

Mean absolute error $(\mathrm{ft})=0.11$

Root mean squared error $(\mathrm{ft})=0.14$

\begin{tabular}{lllll} 
Confined aquifer & JF61 & Toxic burn pits & 1.17 & 1.21 \\
& JF41 & Toxic burn pits & 1.17 & 1.21 \\
& JF31 & Prototype building & 1.17 & 1.21 \\
& JF21 & Riot control pit & 1.17 & 1.21 \\
& JF11 & Riot control pit & 1.17 & 1.21 \\
& JF111 & White phosphorus pit & 1.17 & 1.21 \\
& JF91 & White phosphorus pit & 1.17 & 1.21 \\
Mean error $(\mathrm{ft})=0.04$ & & & & \\
Mean absolute error $(\mathrm{ft})=0.04$ & & & \\
Root mean squared error $(\mathrm{ft})=0.04$ & & & \\
\hline
\end{tabular}


TABLE C.20 Sensitivity Analysis for J-Field Wells: Model Run 47

Model parameter changed from calibrated value Drain conductance decreased one order of magnitude, from 100 to $10 \mathrm{ft}^{2} / \mathrm{d}$

\begin{tabular}{|c|c|c|c|c|}
\hline & $\begin{array}{c}\text { Well } \\
\text { Name }\end{array}$ & $\begin{array}{c}\text { Nearby } \\
\text { Site Feature }\end{array}$ & $\begin{array}{l}\text { Cell Value from } \\
\text { Calibrated Model } \\
\text { (ft MSL) }\end{array}$ & $\begin{array}{l}\text { Model Run } \\
\text { Head } \\
\text { (ft MSL) }\end{array}$ \\
\hline \multirow[t]{7}{*}{ Surficial aquifer } & JF63 & Toxic burn pits & 2.70 & 3.92 \\
\hline & $\mathrm{JF} 43$ & Toxic burn pits & 4.09 & 5.07 \\
\hline & $\mathrm{JF} 33$ & Prototype building & 3.04 & 3.35 \\
\hline & $\mathrm{JF} 23$ & Riot control pit & 1.91 & 1.98 \\
\hline & JF13 & Riot control pit & 2.54 & 2.69 \\
\hline & JF113 & White phosphorus pit & 2.27 & 2.50 \\
\hline & JF93 & White phosphorus pit & 6.19 & 7.23 \\
\hline \multicolumn{5}{|c|}{ Mean error $(f t)=0.57$} \\
\hline \multicolumn{5}{|c|}{ Mean absolute error $(\mathrm{ft})=0.57$} \\
\hline \multicolumn{5}{|c|}{ Root mean squared error $(f t)=0.73$} \\
\hline \multirow[t]{7}{*}{ Confined aquifer } & JF61 & Toxic burn pits & 1.17 & 1.30 \\
\hline & JF41 & Toxic burn pits & 1.17 & 1.30 \\
\hline & JF31 & Prototype building & 1.17 & 1.30 \\
\hline & JF21 & Riot control pit & 1.17 & 1.30 \\
\hline & JF11 & Riot control pit & 1.17 & 1.30 \\
\hline & JF111 & White phosphorus pit & 1.17 & 1.30 \\
\hline & JF91 & White phosphorus pit & 1.17 & 1.30 \\
\hline \multicolumn{5}{|c|}{ Mean error $(\mathrm{ft})=0.13$} \\
\hline \multicolumn{5}{|c|}{ Mean absolute error $(\mathrm{ft})=0.13$} \\
\hline \multicolumn{5}{|c|}{ Root mean squared error $(\mathrm{ft})=0.13$} \\
\hline
\end{tabular}

